\title{
SISTEMA DE DESENVOLVIMENTO PARA CONTROLE ELETRÔNICO DOS MOTORES DE COMBUSTÃO INTERNA CICLO OTTO
}

Carlos Eduardo Milhor

Dissertação apresentada à Escola de Engenharia de São Carlos da Universidade de São Paulo, como parte dos requisitos para obtenção do título de Mestre em Engenharia Mecânica

ORIENTADOR: Prof. Dr. Luís Carlos Passarini

São Carlos

2002 


\section{AGRADECIMENTOS}

Ao Prof. Dr. Luís Carlos Passarini pela orientação.

Ao pessoal do Laboratório de Eletrônica Embarcada e Laboratório de Motores pelo apoio e ajuda.

À Fundação de Amparo à Pesquisa do Estado de São Paulo - FAPESP, pela bolsa de estudo e reserva técnica concedidas.

VOLKSWAGEN Brasil pela doação do motor para testes do sistema.

Alfatest pelos dados técnicos fornecidos e equipamentos doados.

Aos meus familiares e amigos. 


\section{SUMÁRIO}

LISTA DE FIGURAS

LISTA DE TABELAS iii

LISTA DE ABREVIATURAS E SIGLAS iv

LISTA DE SÍMBOLOS vi

RESUMO vii

ABSTRACT viii

1 INTRODUÇÃO 1

2 MOTORES CICLO OTTO E EMISSÕES DE GASES POLUENTES 3

2.1 INTRODUÇÃO 3

2.2 BREVE HISTÓRIA DO MOTOR CICLO OTTO 3

2.3 CICLO DE TRABALHO

2.4 EMISSÃO DE GASES DE ESCAPE E CONSUMO DE COMBUSTÍVEL 6

2.4.1 Emissão de CO

2.4.2 Emissão de $H C$

2.4.3 Emissão de $\mathrm{NO}_{X} \quad 10$

2.4.4 Consumo de combustível 12

3 CONTROLE ELETRÔNICO DOS MOTORES DE COMBUSTÃO INTERNA CICLO OTTO 13 3.1 INTRODUÇÃO 13

3.2 EVOLUÇÃO DO CONTROLE ELETRÔNICO DOS MOTORES CICLO OTTO 13

3.3 CONTROLE ELETRÔNICO DOS MOTORES 20

3.3.1 Injeção eletrônica de combustível $\quad 21$

3.3.2 Controle eletrônico da ignição 23

3.3.3 Controle da recirculação dos gases de escape 25

3.3.4 Sensores 25

3.3.5 Atuadores $\quad 34$

3.3.6 Tratamento do gás de exaustão

3.4 SISTEMAS FUTUROS 43

3.4.1 Novos sistemas catalíticos $\quad 43$

3.4.2 Novas estratégias de controle $\quad 43$

3.4.3 Otimização de sistemas mecânicos 48 
4 METODOLOGIA

4.1 INTRODUÇÃO $\quad 50$

4.2 DESCRIÇÃO DO HARDWARE

4.2.1 Unidade Central de Processamento 51

4.2.2 Sistemas de aquisição de sinais $\quad 52$

4.2.3 Circuitos elétricos de potência 54

4.3 DESCRIÇÃO DO SOFTWARE

4.4 DESCRIÇÃO DO MOTOR UTILIZADO

4.5 INSTRUMENTAÇÃO COMPLEMENTAR

5 RESULTADOS ALCANÇADOS

5.1 INTRODUÇÃO

5.2 RESULTADOS ALCANÇADOS

5.2.1 Teste do sistema de acionamento das VEICs 63

5.2.2 Teste do sistema de energização da bobina de ignição 66

5.2.3 Teste do sistema para acionamento do corretor da marcha lenta 68

6 CONCLUSÕES

$\begin{array}{ll}\text { ANEXO A } & \mathbf{7 4}\end{array}$

$\begin{array}{ll}\text { ANEXO B } & 75\end{array}$

ANEXO C

$\begin{array}{lr}\text { ANEXO D } & 78\end{array}$

$\begin{array}{lr}\text { ANEXO E } & \mathbf{8 0}\end{array}$

LITERATURA REFERENCIADA

LITERATURA CONSULTADA $\quad 85$

APÊNDICE I 


\section{LISTA DE FIGURAS}

FIGURA 01 - Ciclo de trabalho de um motor ciclo Otto. [BOSCH (1988), p. 7, fig. 4] 4

FIGURA 02 - Pressão no cilindro em função da posição do pistão. [BOSCH (1988), p. 5, fig. 2] 5

FIGURA 03 - Emissão de $C O, H C$ e $N O x$ em função do coeficiente de ar $\lambda$. [BOSCH (1995), p. 37 , fig. 3] 8

FIGURA 04 - Emissão de $C O$ em função do ângulo de ignição, $\alpha_{Z}$. [BOSCH (1995), p. 12, fig. 2] 8

FIGURA 05 - Emissão de $H C$ em função do ângulo de ignição, $\alpha_{Z}$. [BOSCH (1995), p. 12, fig. 2] 10

FIGURA 06 - Emissão de $N O_{X}$ em função do ângulo de ignição, $\alpha_{Z}$. [BOSCH (1995), p. 12, fig. 2$] 11$

FIGURA 07 - Consumo específico de combustível em função do coeficiente de ar, $\lambda$, e do ângulo de ignição, $\alpha_{Z}$. [BOSCH (1995), p. 12, fig. 2] 12

FIGURA 08 - Aplicação industrial da tecnologia de injeção de combustível. [AMEY (1995), p. 215, fig. 2]

FIGURA 09 - Mapa para o avanço da ignição. [BOSCH (1988), p. 291, fig. 46]

FIGURA 10 - Posicionamento das válvulas injetoras em um sistema com injeção indireta multiponto. [BOSCH (1995), p. 93, fig. 17]

FIGURA 11 - Comparação entre os tipos de injeção. [BOSCH (1998), p. 39, fig. 2]

FIGURA 12 - Pressão de combustão com ocorrência de knocking. [BOSCH (1988), p. 162, fig. 27] 24

FIGURA 13 - Ponte de Wheatstone. 26

FIGURA 14 - Sensor de pressão do tipo Strain Gage. [RIBBENS (1993), p. 133, fig. 5.5.] 27

FIGURA 15 - Sensor de massa de ar. [BOSCH (1988), p. 257, fig. 36] 28

FIGURA 16 - Sensor de rotação tipo indutivo. [BOSCH (1988), p. 266, fig. 5] 31

$\begin{array}{ll}\text { FIGURA } 17 \text { - Efeito Hall. } & 31\end{array}$

FIGURA 18 - Configuração interna de um circuito integrado Hall. 32

FIGURA 19 - Localização do sensor KS. [BOSCH (1988), p. 132, fig. 39] 33

FIGURA 20 - Sinal do sensor KS. [BOSCH (1988), p. 133, fig. 40] 33

FIGURA 21 - Representação de uma válvula eletromagnética injetora de combustível. [BOSCH (1988), p. 236, fig. 8] 34

FIGURA 22 - Tensão na vela de ignição. [BOSCH (1988), p. 141, fig. 2] 36

FIGURA 23 - Faixa de controle da sonda lambda e redução da concentração de poluentes na exaustão. [BOSCH (1995), p. 18, fig. 1] 38

FIGURA 24 - Representação da sonda lambda. [BOSCH (1995), p. 227, fig. 14] 39

FIGURA 25 - Curva característica de uma sonda lambda operando a uma temperatura de $600^{\circ} \mathrm{C}$. [BOSCH (1995), p. 227, fig. 15] 
FIGURA 26 - Tipos de substratos. [Bosch (1995), p. 24, fig. 8]

FIGURA 27 - Sistema KPI-0041A conectado a um microcomputador. [ARM Evaluation Board (1998), p. 3-3, fig. 3-1]

FIGURA 28 - Interface para aquisição do sinal do sensor Hall.

FIGURA 29 - Interface para interruptores.

FIGURA 30 - Curvas de corrente para o acionamento de uma VEIC.

FIGURA 31 - Circuito para acionamento do estágio de potência da bobina de ignição.

FIGURA 32 - Circuito para acionamento do corretor da marcha lenta

FIGURA 33 - Fluxograma do programa de controle para teste do hardware.

FIGURA 34 - Dispositivo para medida de corrente na VEIC.

FIGURA 35 - Reprodução da tela do osciloscópio mostrando a corrente através da VEIC sob excitação por surto de corrente.

FIGURA 36 - Reprodução da tela do osciloscópio mostrando a corrente através da VEIC sob excitação por surto de tensão.

FIGURA 37 - Medida do sinal de acionamento do módulo de potência da bobina de ignição.

FIGURA 38 - Sinal para acionamento do módulo de potência da bobina de ignição.

FIGURA 39 - Sinal para acionamento do módulo de potência da bobina de ignição (sistema original).

FIGURA 40 - Medida do sinal de acionamento do corretor da marcha lenta.

FIGURA 41 - Acionamento do corretor da marcha lenta com $24 \%$ de largura de pulso.

FIGURA 42 - Acionamento do corretor da marcha lenta com 32\% de largura de pulso.

FIGURA 43 - Sinal atuante para diferentes valores de largura de pulso.

FIGURA 44 - Acionamento do corretor da marcha lenta (sistema original).

FIGURA 45 - Esquema geral do sistema projetado.

FIGURA 46 - Emissão média de CO para veículos movidos a gasool e etanol e o respectivo limite. [http://www.ambiente.sp.gov.br]

FIGURA 47 - Emissão média de $H C$ para veículos movidos a gasool e etanol e o respectivo limite. [http://www.ambiente.sp.gov.br]

FIGURA 48 - Emissão média de $N O_{x}$ para veículos movidos a gasool e etanol e o respectivo limite. [http://www.ambiente.sp.gov.br]

FIGURA 49 - Emissão média de $C H O$ para veículos movidos a gasool e etanol e o respectivo limite. [http://www.ambiente.sp.gov.br]

FIGURA 50 - Média de emissões evaporativas para veículos movidos a gasool e etanol e o respectivo limite. [http://www.ambiente.sp.gov.br] 


\section{LISTA DE TABELAS}

TABELA 01 - Estratégia em função da posição da borboleta de aceleração.

TABELA 02 - Tabela de sinais para gerar centelha na bonina de ignição.

TABELA 03 - Modos de controle e principais características.

TABELA 04 - Dados técnicos do motor AT1000.

TABELA 05 - Dados técnicos do sistema Motronic MP9.0. 


\section{LISTA DE ABREVIATURAS E SIGLAS}

\begin{tabular}{|c|c|}
\hline CAFE & $\begin{array}{l}\text { - Corporate Average Fuel Economy (Economia média unificada de } \\
\text { combustível) }\end{array}$ \\
\hline CARB & $\begin{array}{l}\text { - California Air Resourses Board (Conselho de meios atmosféricos da } \\
\text { Califórnia) }\end{array}$ \\
\hline CONAMA & - Conselho Nacional de meio Ambiente \\
\hline DBW & $\begin{array}{l}\text { - Drive By Wire (Sistema eletrônico de acionamento da borboleta de } \\
\text { aceleração) }\end{array}$ \\
\hline EGR & - Exhaust Gas Recirculation (Recirculação dos gases de exaustão) \\
\hline EMS & - Engine Management Systems (Sistema de gerenciamento do motor) \\
\hline EPA & $\begin{array}{l}\text { - Environmental Protection Agency (Agência de proteção ao meio } \\
\text { ambiente) }\end{array}$ \\
\hline ICE & - Ignição por Centelha Elétrica \\
\hline MAP & - Manifold Absolute Pressure (Pressão absoluta no coletor de admissão) \\
\hline $\mathrm{MBC}$ & - Model-based Controller (Controle baseado em modelo) \\
\hline MBT & - Mean Best Torque (Média do máximo torque) \\
\hline MPFI & - Multipoint Fuel Injection (Injeção de combustível multiponto) \\
\hline NTC & $\begin{array}{l}\text { - Negative Temperature Coefficient (Coeficiente de temperatura } \\
\text { negativo) }\end{array}$ \\
\hline PMI & - Ponto Morto Inferior \\
\hline PMS & - Ponto Morto Superior \\
\hline PWM & - Pulse Width Modulation (Modulação por largura de pulso) \\
\hline PROCONVE & - Programa de Controle da Poluição do ar por Veículos Automotores \\
\hline RISC & - Reduced Instruction Set Code (Código de instrução reduzido) \\
\hline SAE & $\begin{array}{l}\text { - Society of Automotive Engineers (Sociedade de engenharia } \\
\text { automotiva) }\end{array}$ \\
\hline SPFI & - Single Point Fuel Injection (Injeção de combustível monoponto) \\
\hline TWC & - Three-way catalysis (Catalisador de três estágios) \\
\hline UCE & - Unidade de Controle Eletrônico \\
\hline
\end{tabular}


VCT

- Variable Camshaft Timing (Comando de válvulas variável) 


\section{LISTA DE SÍMBOLOS}

$\begin{array}{ll}\mathrm{CHO} & \text { - aldeídos } \\ \mathrm{C}_{2} \mathrm{H}_{5} \mathrm{OH} & \text { - etanol (álcool etílico) } \\ \mathrm{C}_{8} \mathrm{H}_{17} & \text { - gasolina } \\ \mathrm{CO} & \text { - monóxido de carbono } \\ \mathrm{CO}_{2} & \text { - dióxido de carbono } \\ \mathrm{HC} & \text { - hidrocarbonetos não queimados } \\ \mathrm{H}_{2} \mathrm{O} & \text { - água } \\ \mathrm{N}_{2} & \text { - nitrogênio } \\ \mathrm{NO} & \text { - óxido nítrico } \\ \mathrm{NO}_{2} & \text { - dióxido de nitrogênio } \\ \mathrm{NO}_{\mathrm{X}} & \text { - óxido de nitrogênio } \\ \mathrm{O}_{2} & \text { - oxigênio } \\ \mathrm{SO}_{2} & \text { - dióxido de enxofre } \\ \lambda & \text { - coeficiente de ar } \\ \alpha_{\mathrm{Z}} & \text { - ângulo de ignição, }\end{array}$




\section{RESUMO}

MILHOR, C. E. (2002). Sistema de desenvolvimento para controle eletrônico dos motores de combustão interna ciclo Otto. São Carlos. 72p. Dissertação (Mestrado) - Escola de Engenharia de São Carlos, Universidade de São Paulo.

O sistema de gerenciamento dos motores automotivos tem se tornado um avançado sistema de controle. Seu objetivo é fazer com que o nível de emissões de gases poluentes gerados esteja dentro dos padrões exigidos pela legislação de cada país e ao mesmo tempo manter os níveis de desempenho e dirigibilidade. Apresenta as principais características de um típico sistema de gerenciamento de motores a combustão interna, descreve os modos de controle e aponta tendências futuras. Descreve o sistema de controle desenvolvido, o qual servirá de ferramenta de pesquisa para trabalhos que envolvam o estudo de técnicas de controle aplicadas neste contexto e pesquisas envolvendo otimização do rendimento dos motores automotivos.

Palavras chave: injeção eletrônica de combustível, sistema de gerenciamento de motores, sistemas microprocessados 


\begin{abstract}
MILHOR, C. E. Electronic control development system of Otto cycle internal combustion engines. São Carlos, 2002. 72p. Dissertação (Mestrado) - Escola de Engenharia de São Carlos, Universidade de São Paulo.

The automotive engine management system has become an advanced control system. Its objective is to maintain the pollutants gas emissions according to legislations and to maintain the performance and driveability. at the same time. It presents the main features of a tipical internal combustion engine management system, it describes the control modes and it poit out the future tendencies. It describes the control system developed, which one will be usefull as a tool for research involving control applied in this context and engine automotive efficiency optimization researchs.
\end{abstract}

Keywords: electronic fuel injection, engine management system, mricroprocessed systems. 


\section{INTRODUÇÃO}

Com o constante crescimento da frota veicular mundial e o conseqüente aumento da poluição atmosférica devido à liberação de gases tóxicos ao meio ambiente (produto da combustão dos combustíveis utilizados como fonte de energia para os motores); ações governamentais tornaram-se necessárias, no sentido de regulamentar o nível de emissões provenientes dos veículos automotivos. Além dos problemas relacionados com a poluição atmosférica, a questão da capacidade de fornecimento dos combustíveis derivados do petróleo, também foi e continua sendo motivo de preocupação, o que motivou a regulamentação do consumo de combustível.

Desde a implementação de tais regulamentações em diversos países, as medidas restritivas estão se tornando cada vez mais rigorosas, exigindo níveis de emissões de gases poluentes e consumo de combustível progressivamente menores. Com tais exigências, e considerando o avanço tecnológico que a eletrônica sofreu, as montadoras passaram a adotar sistemas de controle eletrônico em seus motores com o intuito de poderem cumprir as legislações governamentais, visto que, os sistemas anteriores, puramente mecânicos, se tornaram incapazes. Tais sistemas são proprietários e impossibilitam quaisquer mudanças por parte de terceiros, motivo pelo qual muitas pesquisas acadêmicas ficaram paralisadas.

Por outro lado, com a possibilidade de se ter um processamento maior, a um custo que diminui com o avanço dos processadores, novas técnicas de controle devem e estão sendo pesquisadas e, na medida do possível, implementadas. Tais técnicas se justificam por aliarem ao baixo nível de emissões de poluentes e consumo de combustível exigidos, as características de melhor desempenho e dirigibilidade.

O objetivo deste trabalho é desenvolver um sistema de controle, com estrutura flexível e aberta, para motores de combustão interna ciclo Otto, que possibilite não só a utilização das técnicas de controle atuais, mas também o desenvolvimento e implementação de novos sensores e atuadores, desenvolvimento de hardware e o desenvolvimento e aplicação de novos algoritmos e técnicas de controle. Isto implicará na ampliação do horizonte de 
experimentação de novas teorias de controle, novos atuadores e sensores, responsáveis pelo gerenciamento do motor; além de, possibilitar a análise de novos componentes mecânicos do motor, novos combustíveis e métodos de preparação da mistura ar-combustível. Com isso, pretende-se ocupar a lacuna criada pelos sistemas proprietários. 


\section{MOTORES CICLO OTTO E EMISSÕES DE GASES POLUENTES}

\subsection{INTRODUÇÃO}

Neste capítulo, faz-se um breve histórico dos motores de combustão interna ciclo Otto, além de, descrever suas principais características de funcionamento. Faz-se também, uma análise da emissão de gases poluentes e do consumo de combustível. Alguns detalhes serão descritos em capítulos posteriores de acordo com a necessidade; e no final deste trabalho, estão disponíveis algumas referências para um estudo mais detalhado dos motores ICE.

\subsection{BREVE HISTÓRIA DO MOTOR CICLO OTTO}

"O motor ICE começou a ser concebido quando em 1862, o físico francês Alphonse Beau de Rochas propôs as condições necessárias para que um motor de combustão interna, a quatro tempos, funcionasse com um máximo de economia. Rochas chegou a descrever também, a seqüência de eventos, por meio do qual a economia e a eficiência poderiam ser conseguidas. Essa seqüência, que totalizava 4 tempos é, em síntese, o que hoje ocorre basicamente em todo motor ICE. Porém, Rochas não chegou a construir motor algum, tendo apenas formulado as condições de funcionamento econômico que ele havia imaginado. $\mathrm{O}$ motor apenas construído experimentalmente em 1872, só foi realizado praticamente em 1876 por Nikolaus Otto, que foi, inclusive, quem determinou o ciclo teórico sob o qual trabalha o motor ICE ${ }^{1}$. Quando a firma alemã Otto und Langen passou a fabricar os motores 4 tempos, de pistões móveis, ligados a um girabrequim, este tipo de motor passou a se chamar popularmente de motor Otto.” (PASSARINI, 1993, p. 1.1)

\footnotetext{
${ }^{1}$ A ignição já era obtida por meio de vela, como nos dias atuais.
} 


\subsection{CICLO DE TRABALHO}

Nos motores 4 tempos, um ciclo de trabalho corresponde a duas voltas da árvore de manivelas. Na medida que a árvore de manivelas (ou girabrequim) realiza o movimento rotativo, os pistões se movem dentro dos cilindros, entre o ponto morto superior (PMS) e o ponto morto inferior (PMI). As bielas são responsáveis por transmitirem o movimento da árvore de manivelas para os pistões. Com as duas voltas da árvore de manivelas, 4 tempos são executados por um cilindro, como mostra a FIGURA 01.

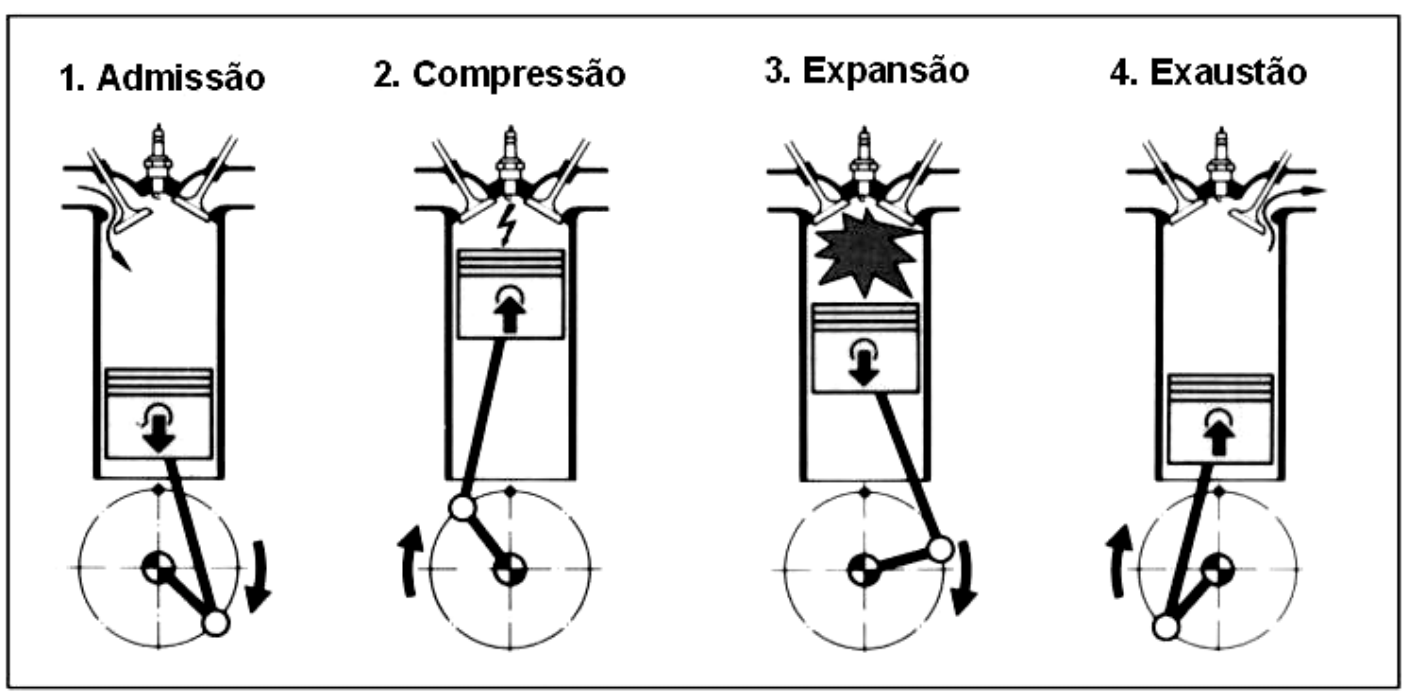

FIGURA 01 - Ciclo de trabalho de um motor ciclo Otto. [BOSCH (1988), p. 7, fig. 4]

Para cada cilindro, um conjunto de válvulas é responsável pela admissão da mistura arcombustível (nos motores de injeção indireta) e exaustão dos produtos da combustão da mistura. Denominadas válvula de admissão e válvula de escape respectivamente, elas podem variar em número de motor para motor. As válvulas são acionadas pelo eixo comando de válvulas, que por sua vez é acionado pela árvore de manivelas.

Os 4 tempos do funcionamento de um motor estão descritos a seguir.

\section{Admissão:}

A admissão se caracteriza pelo movimento do pistão do PMS para o PMI com a válvula de admissão aberta e a válvula de exaustão fechada. Com o movimento do pistão, a mistura ar-combustível flui para dentro do cilindro. 


\section{Compressão:}

Durante a compressão, o pistão se desloca do PMI para o PMS, com as válvulas fechadas, comprimindo a mistura ar-combustível na câmara de combustão. Antes do pistão atingir o PMS, o sistemas de ignição produz uma centelha, através da vela de ignição do respectivo cilindro. A centelha provoca a queima da mistura, fazendo com que a pressão no cilindro se eleve.

\section{Expansão:}

A pressão alta no cilindro, causada pela queima da mistura, faz com que o pistão se desloque do PMS para o PMI, com as válvulas ainda fechadas. É durante a expansão que a energia contida no combustível é liberada, transformado-se em movimento.

\section{Exaustão:}

Na exaustão, o pistão se desloca do PMI para o PMS. A válvula de exaustão se abre fazendo com que o produto da queima da mistura ar-combustível seja expelido do cilindro para a atmosfera.

A FIGURA 02, mostra a variação da pressão no cilindro em função da posição do pistão e a fase que está sendo realizada.

E válvula de exaustão, A válv. admissão, EC válv. exaust. fechada, IC válv. adm. fechada, EO válv. exaust. aberta, IO válv. adm. aberta, $V_{c}$ volume comprimido, $V_{\mathrm{n}}$ volume varrido.

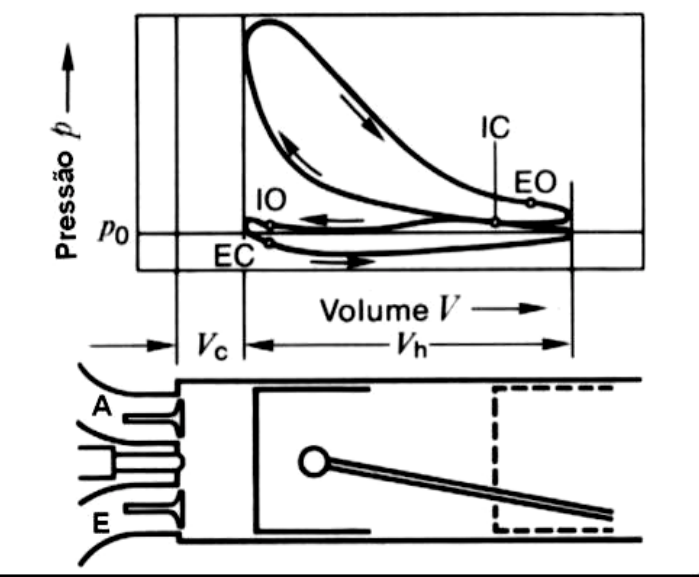

FIGURA 02 - Pressão no cilindro em função da posição do pistão. [BOSCH (1988), p. 5, fig. 2] 
Deve-se lembrar que, os motores ICE tem sido modificado e melhorado ao logo dos anos, de acordo com as necessidades da indústria automobilística. Desta forma os motores têm se tornado mais leves, econômicos e potentes, com a aplicação de novos materiais, melhorias em seus mecanismos, e outras alterações (como geometria e material do coletor de admissão) que resultaram em melhoria na eficiência volumétrica, bem como melhorias relacionadas à eficiência da combustão (geometria da câmara de combustão e novos métodos para formação da mistura ar-combustível).

\subsection{EMISSÃO DE GASES DE ESCAPE E CONSUMO DE COMBUSTÍVEL}

A exaustão do motor de combustão interna ciclo Otto consiste dos produtos da combustão da mistura ar-combustível. No Brasil, o gasool (mistura de gasolina e álcool anidro) $^{2}$ e o álcool hidratado ( $96 \%$ etanol e $4 \%$ de água) são os combustíveis mais utilizados nos veículos com motores de ciclo Otto. Segundo GARCIA (1988), a gasolina é uma mistura de vários hidrocarbonetos e suas propriedades são ajustadas para fornecer as características operacionais desejadas. O etanol (álcool etílico), é uma substância pura.

Conforme GARCIA (1988), admitindo a gasolina com composição média de hidrocarbonetos, representada por $C_{8} H_{17}$ e supondo o ar composto em volume de $21 \%$ de $O_{2}$ e $79 \%$ de $N_{2}$, tem-se:

$$
\mathrm{C}_{8} \mathrm{H}_{17}+12,5 \mathrm{O}_{2}+46,1 \mathrm{~N}_{2} \rightarrow 8 \mathrm{CO}_{2}+8,5 \mathrm{H}_{2} \mathrm{O}+46,1 \mathrm{~N}_{2}
$$

Para o álcool etílico $\mathrm{C}_{2} \mathrm{H}_{5} \mathrm{OH}$, tem-se:

$$
\mathrm{C}_{2} \mathrm{H}_{5} \mathrm{OH}+3 \mathrm{O}_{2}+11,3 \mathrm{~N}_{2} \rightarrow 2 \mathrm{CO}_{2}+3 \mathrm{H}_{2} \mathrm{O}+11,3 \mathrm{~N}_{2}
$$

Durante o processo de combustão, o carbono e o hidrogênio reagem com o oxigênio do ar liberando energia e formando vários compostos químicos (produtos da reação). Se a combustão fosse perfeita, os gases de exaustão consistiriam apenas de dióxido de carbono, $\mathrm{CO}_{2}$, e água, $\mathrm{H}_{2} \mathrm{O}$, conforme eq. (1) e eq. (2), não considerados diretamente prejudiciais ao meio ambiente, embora o $\mathrm{CO}_{2}$ esteja relacionado à degradação da camada de ozônio, o que tem grande influência no efeito estufa.

Mas como a combustão não é perfeita, além de $\mathrm{H}_{2} \mathrm{O}$ e $\mathrm{CO}_{2}$, os gases de exaustão contém monóxido de carbono, $C O$, óxidos de nitrogênio (uniões de oxigênio e nitrogênio) denotados

\footnotetext{
${ }^{2}$ A porcentagem de álcool anidro adicionado à gasolina é definido segundo decreto governamental.
} 
por $N O_{X}$, hidrocarbonetos não queimados, $H C$, entre outros como aldeído, originado a partir da combustão do álcool, e o óxido de enxofre, vindo do processo de refinamento da gasolina.

A mistura estequiométrica, razão ar-combustível para se ter combustão completa, é de 14,9:1, para a gasolina pura (aproximadamente 13:1 para o gasool) e 9:1 para o álcool etílico. Para se detectar o quanto a mistura ar-combustível desvia do valor estequiométrico, define-se o coeficiente, ou constante, de ar lambda, $(\lambda)$, como sendo a relação entre a mistura ar-combustível empregada e a mistura estequiométrica:

$$
\lambda=\frac{\text { mistura ar-combustível empregada }}{\text { mistura ar-combustível estequiométrica }}
$$

Assim, a mistura pode ser classificada da seguinte forma:

$$
\begin{aligned}
& \lambda<1,0 \Rightarrow \text { mistura rica (deficiência de ar) } \\
& \lambda=1,0 \Rightarrow \text { mistura estequiométrica } \\
& \lambda>1,0 \Rightarrow \text { mistura pobre (excesso de ar) }
\end{aligned}
$$

A seguir serão apresentados os principais gases poluentes lançados ao meio ambiente pelos veículos automotivos, os efeitos tóxicos provocados, além da variação na emissão destes gases e do consumo de combustível em função do coeficiente de ar, $\lambda$, e do ângulo de ignição, $\alpha_{Z}$.

\subsubsection{Emissão de $C O$}

Segundo BOSCH (1988), em condições de mistura rica (deficiência de ar), o monóxido de carbono é produto da combustão incompleta da mistura, e portanto, a emissão de $C O$ é fortemente dependente da razão ar-combustível. A concentração de $C O$ no cilindro é alta durante a combustão, enquanto que na subseqüente fase de expansão, uma porção é oxidada formando $\mathrm{CO}_{2}$. Por outro lado, em condições de mistura pobre (excesso de ar), a emissão de $C O$ é baixa e não depende da razão ar-combustível, sendo dependente da não homogeneidade na distribuição da mistura e de flutuações em sua composição entre cada ciclo. A emissão de $C O$ em função da constante de ar pode ser vista na FIGURA 03. Na faixa em torno do ponto estequiométrico, $\lambda=1$, a emissão de $C O$ é determinada pela distribuição uniforme de combustível em cada cilindro. Se alguns dos cilindros estiverem operando com mistura rica e outros com mistura pobre, o resultado será uma média maior de $C O$ emitido, se comparado com a situação em que todos os cilindros estão operando com o mesmo $\lambda$. 
Com relação à ignição, esta tem pouca influência na emissão de $C O$, conforme pode ser visto na FIGURA 04, onde estão dispostas as curvas de emissão para diferentes valores do ponto de ignição ${ }^{3}$.

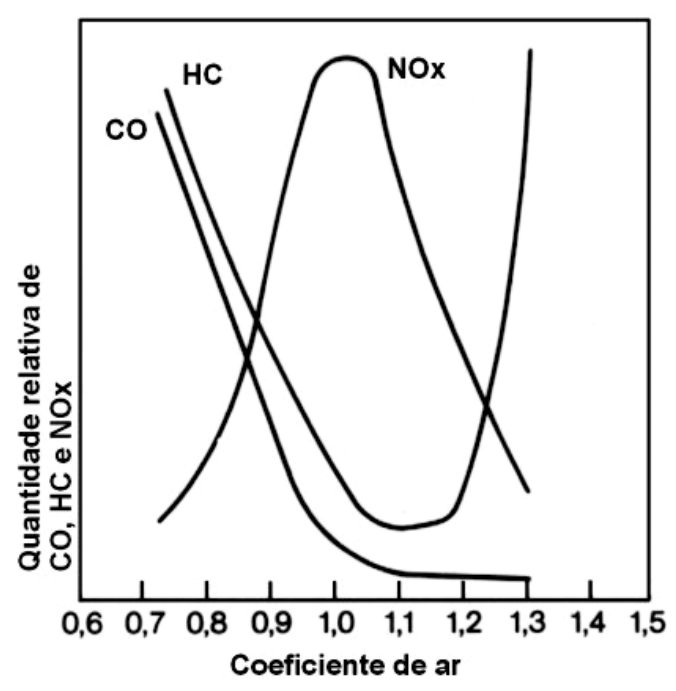

FIGURA 03 - Emissão de $C O, H C$ e $N O x$ em função do coeficiente de ar $\lambda$. [BOSCH (1995), p. 37, fig. 3]

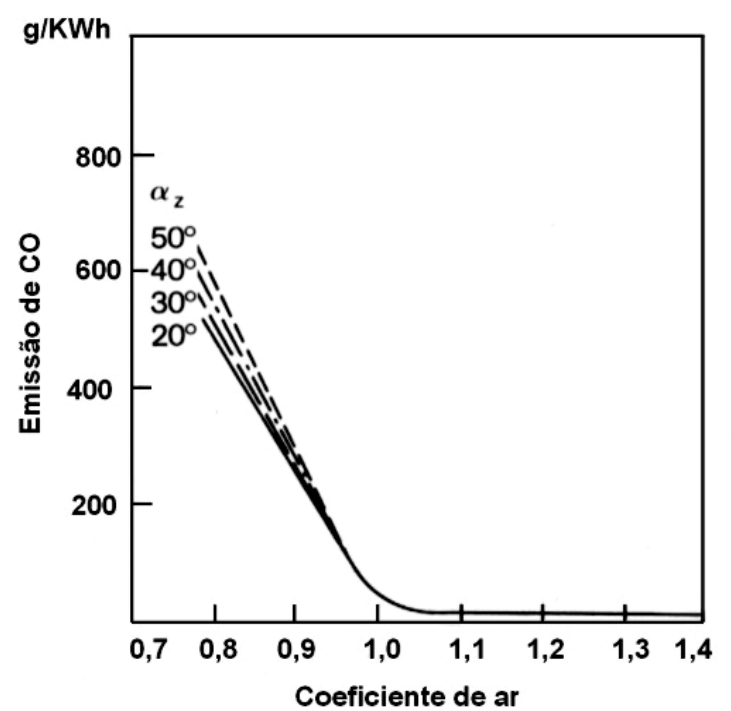

FIGURA 04 - Emissão de $C O$ em função do ângulo de ignição, $\alpha_{Z}$ • [BOSCH (1995), p. 12, fig. 2]

${ }^{3}$ É comum relacionar o ponto de ignição com a posição da árvore de manivelas no "ponto morto superior" (PMS). Assim, o ângulo de ignição, $\alpha_{Z}$, será o ângulo em graus a partir do PMS onde ocorrerá o centelhameto. Um avanço do ponto ou ângulo de ignição no sentido de PMS é chamado de atraso, e o avanço no sentido oposto é chamado adiantamento. 
O monóxido de carbono é um gás incolor e inodoro. Esse gás é tóxico devido à sua alta afinidade com a hemoglobina do sangue, o que causa falta de oxigênio no organismo.

\subsubsection{Emissão de $H C$}

BOSCH (1995), explica também que, como no caso do $C O$, deficiência de ar leva à combustão incompleta da mistura ar-combustível, e portanto, à emissão de hidrocarbonetos não queimados e parcialmente queimados. Desta forma, a emissão de $H C$, ocorre na faixa de mistura rica, e diminui à medida que $\lambda$ aumenta. Na faixa de mistura pobre, porém, a emissão de $H C$ aumenta novamente. A região de emissão mínima de $H C$ fica em torno de $\lambda$ $=1,1 \ldots 1,2$, conforme pode ser visto na FIGURA 03. Esse aumento na emissão na região de mistura pobre é devido às áreas da câmara de combustão que não estão incluídas, ou parcialmente incluídas, na combustão. Essas regiões correspondem às camadas fronteiriças, próximas às paredes do cilindro, onde a chama é extinta por resfriamento, devido à baixa temperatura da câmara de combustão. Quando operando com mistura muito pobre, este efeito é agravado pela combustão atrasada e também por falhas, causando um drástico aumento na emissão de $H C$. Durante a fase de exaustão, os hidrocarbonetos são misturados com os gases quentes. Isso implica na possibilidade de queima de uma parte dos hidrocarbonetos, depois da combustão da mistura, enquanto estão sendo forçados para a exaustão.

Em adição à combustão incompleta, outra fonte de emissão de $H C$ é o que se chama de "blow-by", processo no qual a mistura nova escapa para o cárter através das folgas entre o cilindro e o pistão; porém, através do respiro do cárter para a admissão, esses hidrocarbonetos retornam para a câmara de combustão. Outras duas fontes importantes de $H C$ não queimados são as perdas evaporativas do tanque e do carburador (em veículos que ainda utilizam este). Com relação à ignição, o aumento na emissão de $H C$ é proporcional ao adiantamento desta, já que as reações na fase de expansão e exaustão são desfavorecidas devido à baixa temperatura de exaustão. Esta tendência só é revertida na faixa de mistura muito pobre, onde a velocidade de combustão é tão baixa que, com o atraso da ignição, a combustão não estará completa quando a válvula de exaustão abrir. A FIGURA 05, ilustra a emissão de $H C$ em função do ângulo de ignição, $\alpha_{Z}$.

O gás de exaustão contém uma variedade de hidrocarbonetos com características diferenciadas:

Hidrocarbonetos saturados (parafinas) são praticamente inodoros, têm um efeito narcótico e causam leve irritação nas mucosas. 
Hidrocarbonetos insaturados (olefina e acetileno) têm um suave cheiro e em alguns casos podem levar à irritação das mucosas.

Hidrocarbonetos aromáticos têm um cheiro característico. São mais conhecidos como toxinas com um efeito narcótico, em parte carcinogênico (benzopireno). Aldeídos (formaldeidos) têm um odor pungente e irritam os olhos e nariz, mesmo em baixas concentrações.

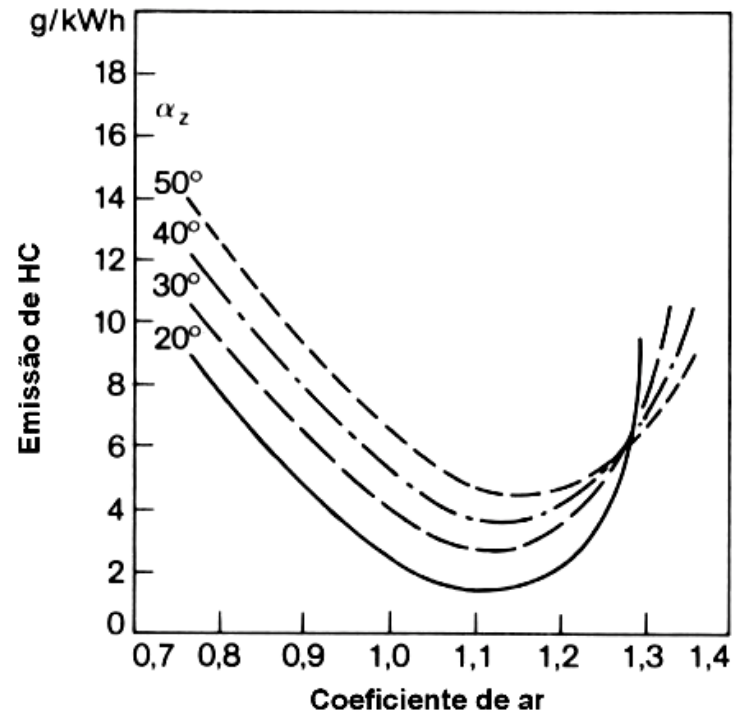

FIGURA 05 - Emissão de $H C$ em função do ângulo de ignição, $\alpha_{Z}$ [ [BOSCH (1995), p. 12, fig. 2]

\subsubsection{Emissão de $\mathrm{NO}_{X}$}

Ainda segundo BOSCH (1995), picos de temperatura na câmara de combustão, e a duração de seu efeito, têm uma influência decisiva na formação de $N O$ (óxido nítrico). Além de $N O$, também são produzidos em pequena escala dióxido de nitrogênio $\left(\mathrm{NO}_{2}\right)$ e óxido nitroso $\left(N_{2} O\right)$. A dependência da emissão de $N O_{X}$ com relação ao fator $\lambda$ é exatamente o inverso da emissão de $H C$, sendo que, na faixa de mistura rica, ocorre o aumento de $N O_{X}$ emitido com o aumento de $\lambda$, como resultado do aumento da concentração de oxigênio. $\mathrm{Na}$ região de mistura pobre, a emissão de $N O_{X}$ diminui com o aumento de $\lambda$, pois nesta faixa, aumentando a concentração de oxigênio, a temperatura da câmara de combustão diminui. A emissão máxima ocorre com uma mistura levemente empobrecida, localizada em uma faixa em torno de $\lambda=1,05$ a 1,1. A emissão de $N O_{X}$ em função de $\lambda$ pode ser vista na FIGURA 03. Com relação à ignição, o adiantamento leva à um aumento da temperatura da câmara de combustão, causando um aumento na emissão de $N O_{X}$ em toda a faixa de $\lambda$, como pode ser 
visto na FIGURA 06. Essa alta temperatura move o equilíbrio químico para a formação de $N O_{X}$ e, sobretudo, aumenta sua velocidade de formação.

Óxido nítrico é um gás incolor e na presença de ar, se oxida formando $\mathrm{NO}_{2}$. É considerado como sendo uma severa hemotoxina, pois sua combinação com a hemoglobina do sangue causa paralisia central. $\mathrm{NO}_{2}$ é um gás castanho avermelhado com um odor pungente bem característico. Causa uma pronunciada irritação no sistema respiratório e danos ao tecido pulmonar. $\mathrm{NO}$ e $\mathrm{NO}_{2}$ são usualmente designados conjuntamente como $N O_{X}$. Além dos danos já citados, $N O_{X}$ pode afetar diretamente o meio ambiente, como por exemplo, através da contribuição para formação de chuva ácida.

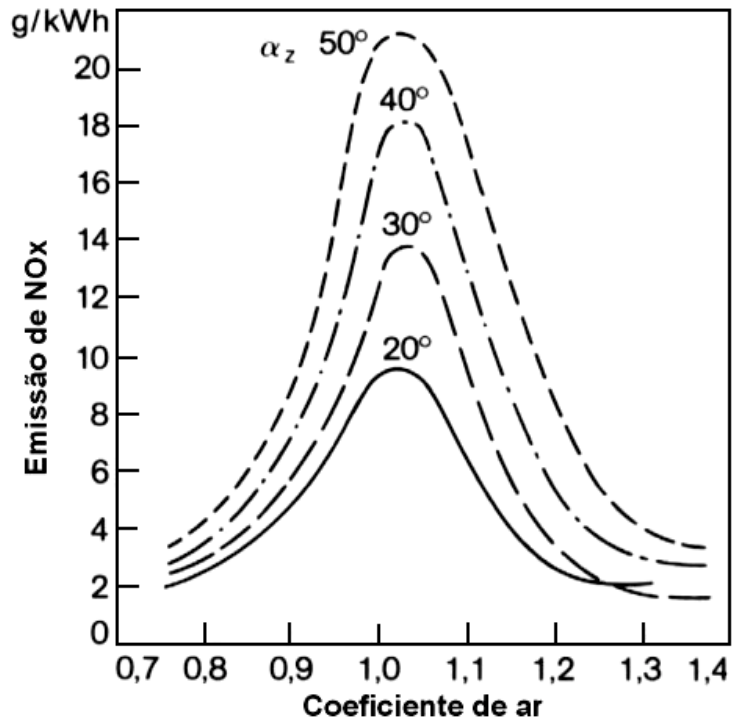

FIGURA 06 - Emissão de $N O_{X}$ em função do ângulo de ignição, $\alpha_{\mathrm{Z}}$ [ [BOSCH (1995), p. 12, fig. 2]

Além do coeficiente de ar e do ângulo de ignição, características construtivas, como taxa de compressão, forma da câmara de combustão, tempo de abertura das válvulas, entre outras; também podem influenciar a emissão de gases poluentes. As condições de operação como velocidade de rotação e carga do motor, também interferem na emissão dos gases poluentes.

Outros componentes que compreendem uma pequena porcentagem do gás de exaustão, além dos gases anteriormente citados, podem ser lançados ao meio ambiente, dentre os quais pode-se citar a fuligem, que é produzida em condições de deficiência de ar extrema, dióxido de enxofre $\left(\mathrm{SO}_{2}\right)$, compostos de chumbo (antidetonante), fósforo entre outros. 


\subsubsection{Consumo de combustível}

A influência do ângulo de ignição no consumo de combustível é o oposto do que foi visto para a emissão de poluentes. Com o aumento de $\lambda$, a fim de se manter combustão ótima, deve-se adiantar a ignição para compensar a baixa velocidade de combustão. Portanto, o adiantamento da ignição implica em baixo consumo de combustível e alto torque. A FIGURA 07, ilustra o consumo específico de combustível em função de $\lambda$ e $\alpha_{Z}$.

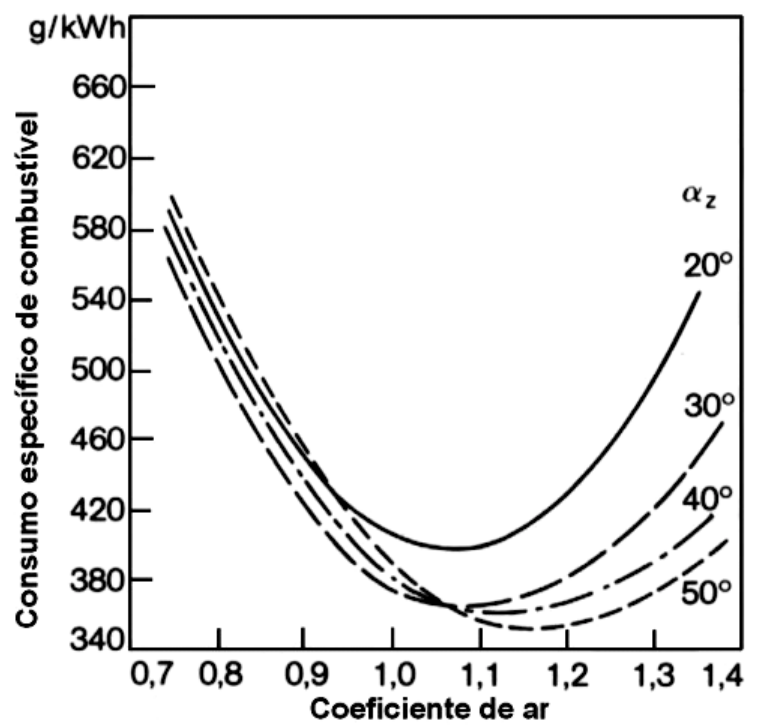

FIGURA 07 - Consumo específico de combustível em função do coeficiente de ar, $\lambda$, e do ângulo de ignição, $\alpha_{\mathrm{Z}}$ [ [BOSCH (1995), p. 12, fig. 2] 


\section{CONTROLE ELETRÔNICO DOS MOTORES DE COMBUSTÃO INTERNA CICLO OTTO}

\subsection{INTRODUÇÃO}

Neste capítulo, mostra-se a evolução do controle eletrônico dos motores de combustão interna dos veículos automotivos, evolução esta que teve como principais fatores as legislações governamentais que restringem o nível de poluentes lançados ao meio ambiente, através dos gases de exaustão, e a economia de combustível. Mostra também, o funcionamento do sistema de controle, com as principais grandezas controladas, os modos de funcionamento e novas estratégias de controle; e por fim, aponta as tendências para os sistemas futuros.

\subsection{EVOLUÇÃO DO CONTROLE ELETRÔNICO DOS MOTORES CICLO OTTO}

Em meados da década de 1950, começaram a ser desenvolvidos os primeiros sistemas mecânicos de injeção de combustível para motores de ciclo Otto de veículos automotivos. De acordo com GIVENS (1976), em 1954, a Mercedes-Benz lançou seu modelo esportivo, o 300SL, com um sistema de injeção direta da Bosch, o qual injetava combustível em alta pressão, diretamente na câmara de combustão, de maneira similar aos motores Diesel. Em 1957 a injeção direta foi convertida para a indireta, sendo que, ainda estava em produção na data do referido trabalho.

No ano de 1957, a General Motors e a Bendix apresentaram seus respectivos sistemas de injeção de combustível para motores a combustão interna ciclo Otto, no Encontro Anual da SAE em Detroit, USA; enquanto isso, a Bosch apresentava o seu projeto no encontro da SAE Cleveland Section, Cleveland, USA. 
Em Detroit, DOLZA et al. (1957) apresentaram o sistema de injeção de combustível da General Motors, um sistema com injeção de fluxo contínuo, e as válvulas injetoras direcionando o jato de combustível nas válvulas de admissão de cada cilindro. O sistema era puramente mecânico e dosava o combustível na quantidade adequada nas diferentes condições de funcionamento. Os ensaios em dinamômetro mostraram que, em condições de regime, o sistema de injeção era pouco superior ao carburador convencional, as curvas de potência levantadas para um motor de 4 cilindros, equipado com os dois sistemas, eram muito próximas. Mas, os ensaios realizados em veículos mostraram que, durante as acelerações o sistema da GM obtinha significante vantagem sobre o carburador, com uma resposta mais rápida e sem falhas.

No mesmo encontro, WINKLER \& SUTTON (1957) apresentaram o sistema Bendix de injeção de combustível, o Electrojector, um sistema com injeção seqüencial ${ }^{4}$ que consistia de um modulador eletrônico e um comutador como seus principais componentes. De acordo com a condição de operação do motor, o modulador gerava um pulso elétrico com uma determinada largura, fazendo com que a válvula injetora permanecesse aberta o tempo necessário para fornecer a quantidade de combustível adequada para aquela condição. $\mathrm{O}$ Electrojector foi portanto, o primeiro sistema eletrônico analógico de injeção de combustível. Ensaios realizados em um motor de 4 cilindros mostraram que o sistema apresentou melhores resultados para o torque, potência e bem como para o consumo específico de combustível quando comparado com o mesmo motor equipado com carburador.

NYSTROM (1958), em Cleveland, apresentou o sistema Bosch de injeção de combustível. Este sistema, como o da GM, era composto por componentes mecânicos. Mas ao invés de ser um sistema de fluxo contínuo, a Bosch optou por um sistema temporizado. A quantidade de combustível que a bomba injetora forneceria para as válvulas injetoras era determinada por um controlador de acordo com a condição de operação do motor. Como nos sistemas anteriores, o combustível era injetado próximo à válvula de admissão, sendo que um controlador da bomba injetora direcionava o combustível para a válvula injetora correta. Ensaios dinamométricos, foram realizados em um motor V-8 e mostraram que, o motor com o sistema de injeção apresentava uma curva de torque melhor, com um torque máximo maior que com o motor carburado, além de, um valor de torque constante para uma faixa maior de rotações. O consumo específico também foi menor com o sistema de injeção. Ensaios de pista mostraram que houve uma melhora de 5 a $15 \%$ no consumo de combustível, melhora

\footnotetext{
${ }^{4}$ Consultar seção 3.3.1 Injeção eletrônica de combustível, para um definição dos tipos de injeção.
} 
esta que foi atribuída ao fato de haver uma distribuição mais homogênea e com corte de combustível durante as desacelerações.

Segundo NYSTROM (1958), outros sistemas estavam sendo apresentados como o sistema Borg-Warner, semelhante ao da Bosch e o sistema Lucas.

Com exceção do sistema da Bendix, todos os outros eram compostos por componentes mecânicos. A eletrônica teria seu uso consolidado apenas algumas décadas depois. O objetivo principal dos sistemas de injeção era eliminar problemas do carburador, fornecendo uma mistura ar-combustível adequada para todas as condições de operação do motor, eliminar os problemas com a partida a frio e aquecimento e obter uma maior economia de combustível.

Mas, segundo PASSARINI (1993), os usuários não aceitavam as inovações e, além disso, durante mais de 100 anos sendo possível controlar o motor fazendo uso de controles fluídicos, as montadoras relutaram em abandonar uma tecnologia que tão bem dominavam e que havia exigido um alto investimento financeiro.

Este fenômeno pode ser observado na, FIGURA 08, que mostra um certo avanço dos EUA, mas logo se fecham para a aplicação da tecnologia de injeção de combustível, voltando a utilizar o carburador. Por outro lado, a indústria européia teve uma aplicação cada vez maior da injeção de combustível em veículos novos.

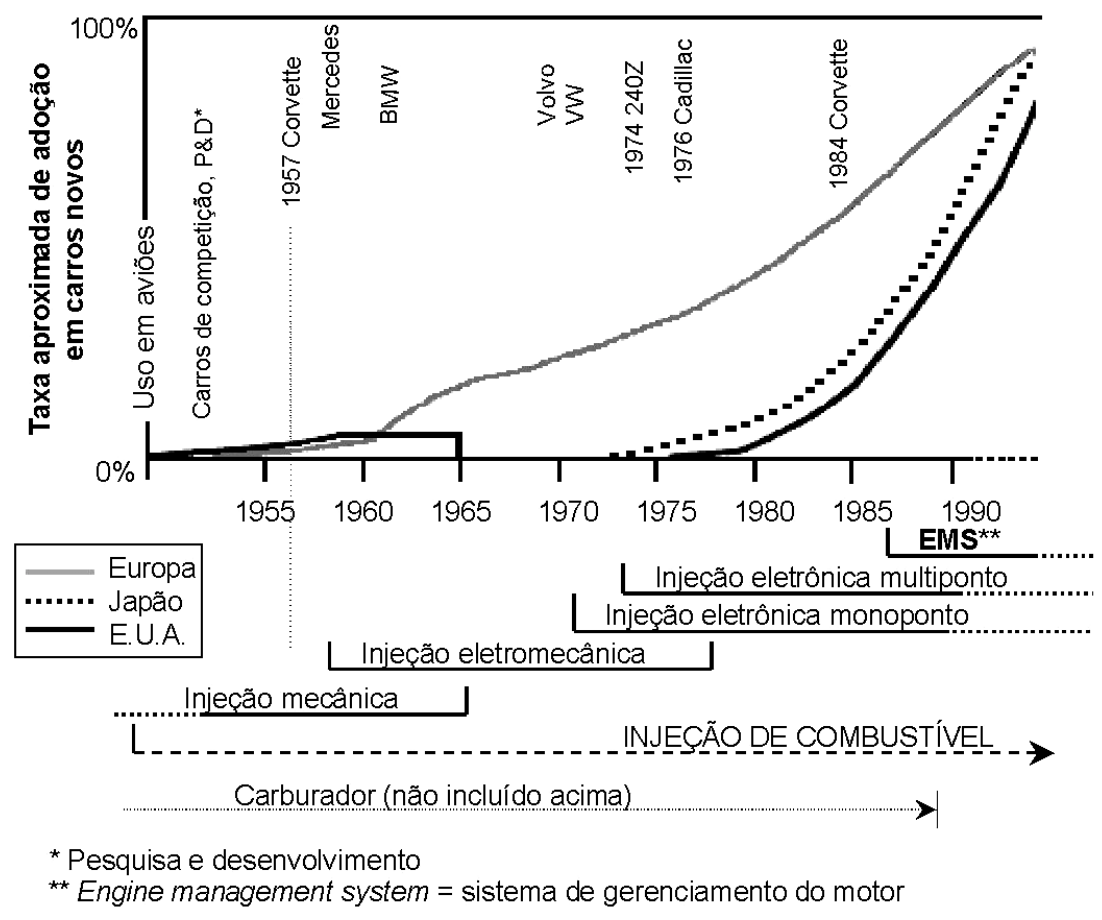

FIGURA 08 - Aplicação industrial da tecnologia de injeção de combustível. [AMEY (1995), p. 215, fig. 2] 
De acordo com AMEY (1995), os Europeus na década de 1960 e os Japoneses em meados da década de 1970, lideraram o desenvolvimento e aplicação da injeção de combustível em automóveis e a tecnologia de gerenciamento de motores afins. No final da década de 1970, os consumidores americanos passaram a acreditar que os carros europeus e japoneses eram mais avançados tecnologicamente e de qualidade superior que a maior parte dos carros americanos

Segundo RIBBENS \& MANSOUR (1993), a motivação para o controle eletrônico dos motores veio em parte devido a dois requisitos governamentais. O primeiro aconteceu como resultado da legislação para regulamentar a emissão de gases de exaustão dos automóveis. O segundo foi um impulso para se melhorar a média nacional de economia de combustível com uma regulamentação governamental, ambos os requisitos vindo do governo dos EUA. Em 1966 o estado da Califórnia ${ }^{5}$ (EUA), impôs limites para a emissão dos gases $H C, C O$ e $N O_{X}$ em todo o estado.

A partir do momento em que o governo federal dos Estados Unidos da América, sob a autoridade da $\mathrm{EPA}^{6}$, também passou a restringir o nível de emissões e os limites se tornaram, progressivamente, mais difíceis de serem cumpridos (entre as décadas de 1970-1980), a indústria automobilística americana passou a adotar o controle eletrônico em seus motores, primeiramente com os carburadores eletrônicos e depois com os sistemas de injeção eletrônica, visto que, o controle tradicional não era capaz de cumprir as exigências governamentais e manter desempenho adequado do motor.

Além do nível de emissões de gases poluentes, RIBBENS \& MANSOUR (1993), explica que, a legislação passou a regulamentar o consumo de combustível através da $\mathrm{CAFE}^{7}$, onde os requisitos não são baseados em um único veículo, mas estão estabelecidos em termos de uma taxa média de milhas por galão para a produção de todos os modelos por uma montadora para qualquer ano.

Segundo PASSARINI (1993), o custo para o cumprimento desses requisitos cai sobre o desempenho do motor. Para atender tais exigências usando controle mecânico, como no passado, não haveria custo efetivo. Mas tais tipos de controle não teriam a capacidade de reproduzir funções de forma acurada ao longo de toda a gama de veículos em produção, sob todas as condições de operação, durante toda a vida do veículo e permanecer dentro das tolerâncias para cumprir os requisitos governamentais.

\footnotetext{
${ }^{5} \mathrm{Na}$ Califórnia, a agência de proteção ao meio ambiente é a CARB, Conselho de meios atmosféricos da Califórnia.

${ }^{6}$ Agência de proteção ao meio ambiente. Entidade governamental dos EUA.

${ }^{7}$ Economia média unificada de combustível.
} 
Por isso, a indústria automobilística americana retomou o desenvolvimento e aplicação da tecnologia de injeção de combustível, como mostra a FIGURA 08.

Segundo GLÖCKLER \& MANGER (1981), em 1967, a Bosch lança o sistema DJetronic, um sistema com controle eletrônico analógico, com comando pela pressão no coletor de admissão. Após esse sistema, outras versões do mesmo fabricante surgiram, dando início a uma nova era na injeção de combustível.

De acordo com GIVENS (1976), a Cadillac, em 1973, iniciou um programa para a implementação de sistemas de injeção eletrônica em seus veículos. O sistema que passou a ser instalado, como equipamento de série nos modelos Seville, e como opcional em outros modelos, era um sistema da Bendix desenvolvido em parceria com a Bosch. Este sistema era uma versão mais sofisticada daquele apresentado em 1957. Nesta versão, o sinal para ativar as válvulas injetoras, era enviado diretamente pela UCE (diferentemente do sistema anterior, onde o sinal era enviado ao comutador, instalado junto ao distribuidor, e então enviado à válvula injetora correta). A UCE, que era um computador analógico pré programado, recebia os sinais dos sensores gerando um pulso com duração adequada para ativar os bicos injetores e controlava também a recirculação dos gases de escape (discutido mais adiante) e outras operações.

No mesmo ano, a Bosch introduziu o K-Jetronic, um sistema com controle mecânicohidráulico, com medição do volume de ar e que injetava o combustível continuamente nas válvulas de admissão. O L-Jetronic, da mesma época, era um sistema com controle eletrônico e injeção de combustível intermitente. Algumas versões destes sistemas, principalmente os que eram destinados ao mercado norte-americano, atuavam em malha fechada, ou seja, utilizando sensor de $O_{2}$ (ou sonda lambda) ${ }^{8}$, para poder cumprir os requisitos impostos pela legislação daquele período. O sensor de $O_{2}$ será discutido no item 3.3.6.

No início da implementação do controle eletrônico, utilizavam circuitos analógicos. Mas logo, a tecnologia dos circuitos integrados passou a ser viável e o uso da eletrônica digital tornou o controle eletrônico mais confiável, com maior facilidade para o desenvolvimento e mais barato. A partir deste momento, os sistemas de controle tiveram um grande avanço e a ignição também passou a ser controlada eletronicamente. Segundo SIMANAITIS (1977), um sistema de ignição microprocessado desenvolvido pela Delco-Remy passou a ser usado em

\footnotetext{
${ }^{8}$ A sonda lambda é um sensor que, instalado no duto de exaustão, determina a razão ar-combustível.
} 
veículos como item de série. Denominado MISAR, esse sistema controlava o momento exato da ignição e a duração do tempo de energização da bobina, a partir da medida da rotação da árvore de manivelas, pressão na admissão e a temperatura do líquido de arrefecimento.

No final da década de 1970, os conversores catalíticos de três estágios (TWC), foi objeto de estudo da Volvo em conjunto com a Bosch para se reduzir a quantidade de $H C, C O, N O_{X}$ lançados na atmosfera. Descobriu-se que, para que o conversor TWC tenha um bom rendimento e sua vida útil seja prolongada, a mistura ar-combustível deve ser mantida dentro de uma faixa muito próxima do valor estequiométrico. Para se conseguir manter a mistura nessa proporção, utiliza-se a realimentação por sonda lambda. Assim os sistemas de injeção de combustível passaram a trabalhar em malha fechada, tornando-os mais acurados e com isso conseguiu-se diminuir a concentração dos gases $\mathrm{HC}, \mathrm{CO}, N \mathrm{O}_{X}$ lançados ao meio ambiente.

RIBBENS \& MANSOUR (1993) explica que, outro conversor, menos eficiente que o de três estágios, é o denominado conversor catalítico oxidante. Utilizado antes do início da era do controle de emissões, este conversor tem como princípio, oxidar o $\mathrm{HC}$ e o $\mathrm{CO}$ para $\mathrm{H}_{2} \mathrm{O}$ e $\mathrm{CO}_{2}$. Para tanto, é necessário a adição de oxigênio para que o processo ocorra, o que é feito por uma bomba de ar, chamado ar secundário.

Em 1979 foi introduzido o Motronic pela Bosch, um sistema com processamento digital das funções do motor. Esse sistema unia o L-Jetronic e uma ignição eletrônica mapeada. Começava então a integração dos sistemas, onde uma nova abordagem passou a ser adotada, ou seja, o sistema passou a ser responsável pelo gerenciamento do motor como um todo, foi o início dos chamados sistemas EMS (Engine Management Systems), contendo os subsistemas de injeção e ignição e o controle de outras funções como a recirculação dos gases de escape entre outras.

No Brasil, de acordo com SECRETARIA DE ESTADO DO MEIO AMBIENTE, a necessidade de um programa nacional que contemplasse as emissões atmosféricas de origem veicular, começou a tomar corpo no início da década de 1980, a partir da constatação de que a grave poluição ambiental verificada nos grandes centros urbanos era causada predominantemente por poluentes gerados na queima de combustíveis em veículos automotores. Procurando viabilizar um programa de controle de emissões veiculares que fosse tecnicamente factível e economicamente viável, o Conselho Nacional de Meio Ambiente - CONAMA criou, em 1986, o Programa de Controle da Poluição do Ar por Veículos Automotores - PROCONVE. O PROCONVE tem como objetivos a redução dos níveis de emissão de poluentes nos veículos automotores, além de, incentivar o desenvolvimento tecnológico nacional, tanto na engenharia automotiva, como em métodos e 
equipamentos para a realização de ensaios e medições de poluentes. Os limites máximos de emissão de poluentes foram fixados com um cronograma específico para três categorias distintas de veículos, são elas: "Veículo Leve de Passageiros" (automóveis); "Veículo Leve Comercial" (pick-up, van, utilitários, etc) e "Veículo Pesado" (ônibus e caminhões). Os resultados práticos e positivos alcançados até o ano de $1999^{9}$, podem ser vistos no APÊNDICE I, que mostra redução dos índices de emissão de monóxido de carbono, hidrocarbonetos, óxidos de nitrogênio, aldeídos $(\mathrm{CHO})$ e emissões evaporativas por veículos leves.

Deve-se ressaltar que o Brasil, devido a sua frota específica movida a etanol, foi o primeiro país a legislar a emissão de aldeídos e a corrigir a respectiva emissão evaporativa.

Segundo BARTOLOMAIS Jr. (1989), o controle eletrônico dos motores passou a ser empregado nos veículos de série no Brasil em 1988 pela VW, equipando um de seus modelos esportivos com um sistema analógico (Bosch LE-Jetronic) com um módulo separado para o controle da ignição. No ano seguinte, a GM também passou a equipar um de seus modelos com a injeção eletrônica. No ano de 1991 todas as montadoras nacionais estavam empregando a injeção eletrônica. A GM com um sistema com injeção central (apenas uma válvula injetora) para alguns modelos e, mais tarde, a injeção com multiponto para os modelos esportivos e os modelos de luxo. A FIAT passou a empregar um sistema de injeção eletrônica combinado com um distribuidor diferenciado do convencional. A então Autolatina (joint-venture entre Ford e VW) mesmo empregando a injeção eletrônica nos modelos mais sofisticados (Gol GTi e Santana Executivo), continuou empregando o carburador com auxílio eletrônico, o então chamado, carburador eletrônico, nos modelos mais simples.

O avanço no emprego da injeção eletrônica no Brasil, ocorreu em um momento de crescimento da produção de modelos a gasolina. Até então, os fabricantes se queixavam de que os motores a etanol exigiam sistemas especiais de injeção, não disponíveis no mercado internacional.

A partir deste momento, a aplicação da tecnologia de gerenciamento de motores a combustão interna teve um grande crescimento e em 1997 todos os carros produzidos no pais já possuíam injeção eletrônica, resultado tanto da legislação de emissões, como pela melhor relação custo/benefício. Atualmente, a maior parte dos veículos produzidos e comercializados no Brasil acompanham a tendência mundial.

\footnotetext{
${ }^{9}$ Dados mais atualizados não foram encontrados.
} 


\subsection{CONTROLE ELETRÔNICO DOS MOTORES}

O sistema de controle dos motores a combustão interna compreende um conjunto de subsistemas. O principal destes, o sistema de injeção de combustível, é responsável por controlar a quantidade ideal de combustível para cada condição de operação do motor. Os sistemas de controle da ignição, recirculação de gases e outros que variam de acordo com o fabricante completam o sistema de controle do motor que atuando de maneira integrada, gerenciam seu funcionamento, de modo que, opere de forma otimizada, ou seja, minimizando o consumo de combustível e a emissão de poluentes (cumprindo a legislação), maximizando a performance, dirigibilidade e vida útil.

O gerenciamento do motor a partir dos subsistemas descritos, passou a ser possível com o desenvolvimento da eletrônica, o que viabilizou a utilização de sistemas microprocessados, realizando o controle digital do motor.

Para que o sistema de controle possa gerenciar o funcionamento do motor, é necessário que a UCE receba sinais de sensores indicando a condição de funcionamento em um dado momento. Esses sinais são processados, pela UCE, e então, sinais de comando são enviados para os atuadores de forma que o motor opere de acordo com o mapeamento.

Uma exigência básica para qualquer sistema de controle, é que se conheça a "planta", ou seja, o sistema a ser controlado. No caso dos motores a combustão interna, o conhecimento do sistema a ser controlado vem de um processo experimental denominado de mapeamento ${ }^{10}$. Este processo é realizado em uma bancada dinamométrica, e a partir das curvas de torque do motor, potência, consumo específico e nível de emissões desejados, monta-se tabelas de carga $X$ rotação $X$ ponto de ignição, carga $X$ rotação $X$ tempo de injeção, entre outras como temperatura do motor $\mathrm{X}$ tempo de injeção (utilizada na partida do motor), responsáveis pela compensação no tempo de injeção, ponto de ignição e etc. Estas curvas são armazenadas na memória da UCE em forma de tabelas (lookup tables) que serão recuperadas, ponto a ponto, de acordo com a condição de operação do motor. A FIGURA 09, ilustra uma mapa do avanço da ignição em função da carga e rotação do motor.

A seguir, serão descritos os principais subsistemas de um típico sistema de gerenciamento eletrônico de motores, indicando as grandezas medidas e os modos de controle. Para cada condição de operação do motor, define-se um modo de controle. Cada modo de controle corresponde a uma determinada rotina realizada pelo programa de controle

\footnotetext{
${ }^{10}$ Alguns autores definem este processo como calibração.
} 
e que é ativado a partir dos sinais recebidos pelos sensores. Deve-se destacar que o sistema de gerenciamento atua de maneira integrada tanto no sistema de injeção como no sistema de ignição e recirculação de gases de escape. Mas para fins didáticos, os modos de controle serão descritos separadamente para cada subsistema.

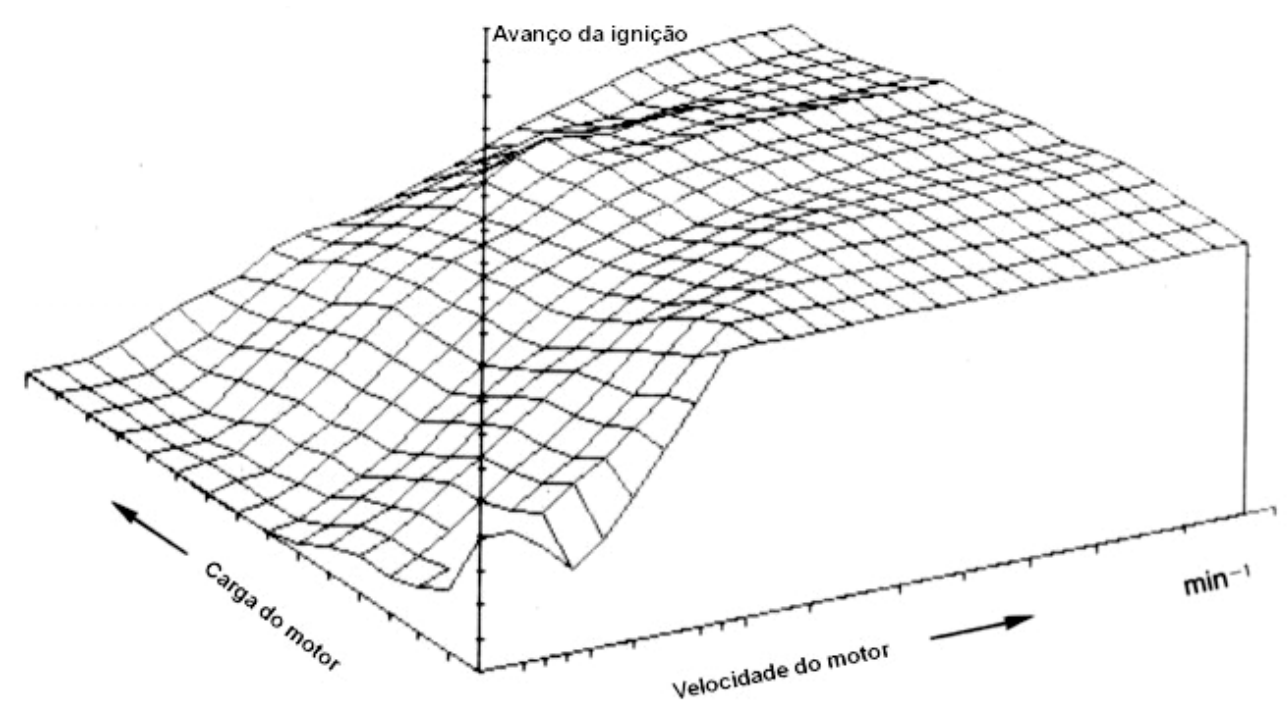

FIGURA 09 - Mapa para o avanço da ignição. [BOSCH (1988), p. 291, fig. 46]

\subsubsection{Injeção eletrônica de combustível}

O sistema de controle eletrônico da injeção de combustível tem a função de dosar corretamente a quantidade de combustível em função das condições de operação do motor. O combustível é dosado através do controle do tempo de acionamento da válvula eletromagnética injetora de combustível (VEIC). Mais detalhes das VEICs serão descrito em 3.3.5.

Através dos sinais dos vários sensores instalados no motor, a UCE identifica a condição de operação que o motor está submetido, e então, passa a executar um específico modo de controle. Segundo RIBBENS \& MANSOUR (1993), são definidas seis condições de operação do motor que afetam o sistema de injeção de combustível. Cada condição de operação exige a atuação de um modo de controle. O ANEXO A resume os seis modos de controle destacando suas principais características.

As FIGURA 03 e FIGURA 07 ilustram a influência da mistura ar-combustível na emissão de gases poluentes e no consumo específico de combustível respectivamente.

A disposição das VEICs varia de sistema a sistema. Nos sistemas mais simples, empregados em alguns dos primeiros sistemas de controle eletrônico, utilizava-se apenas 
uma válvula injetora, a qual era instalada acima ou abaixo da borboleta de aceleração. Tais sistemas eram denominados de sistemas de injeção central de combustível, monoponto ou ainda throttle-body. No sistema de injeção individual (ou multiponto), utiliza-se uma válvula injetora para cada cilindro, os quais injetam o combustível a montante da válvula de admissão do respectivo cilindro, como mostra a FIGURA 10.

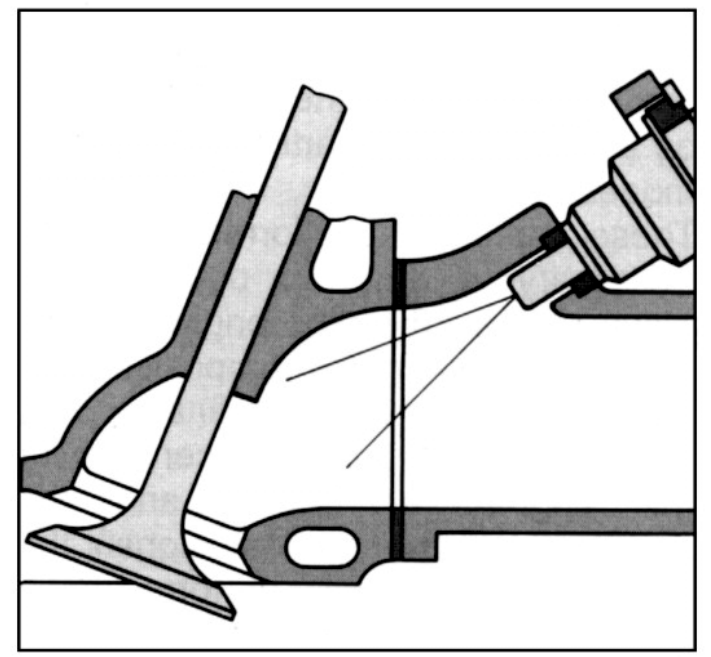

\section{FIGURA 10 - Posicionamento das válvulas injetoras em um sistema com injeção} indireta multiponto. [BOSCH (1995), p. 93, fig. 17]

Em sistemas com injeção individual, o tipo de injeção pode ser (BOSCH, 1998, p. 40):

Injeção simultânea: todas as VEICs são acionadas simultaneamente duas vezes por ciclo;

Injeção em grupo: são reunidos dois grupos de VEICs, sendo que cada grupo injeta uma vez por ciclo. O intervalo de tempo entre os dois grupos é de um giro da árvore de manivelas. Essa disposição permite uma seleção da posição da injeção em função do ponto de operação e evita a indesejada injeção na válvula aberta em outras áreas do mapeamento;

Injeção seqüencial: este tipo de injeção oferece o maior grau de liberdade. A injeção é feita em igual posição com relação aos diversos cilindros. A posição da injeção pode ser programada livremente e pode ser adaptada aos respectivos critérios de otimização. Este tipo de injeção é o mais empregado atualmente.

A FIGURA 11, ilustra os tipos de injeção citados anteriormente.

As vantagens em se ter a injeção controlada eletronicamente são: 
$\checkmark$ Menor consumo de combustível;

$\checkmark$ Maior potência;

$\checkmark$ Aceleração sem atraso;

$\checkmark$ Melhora da partida a frio e fase de aquecimento;

$\checkmark$ Baixo teor de poluentes no gás de escape.

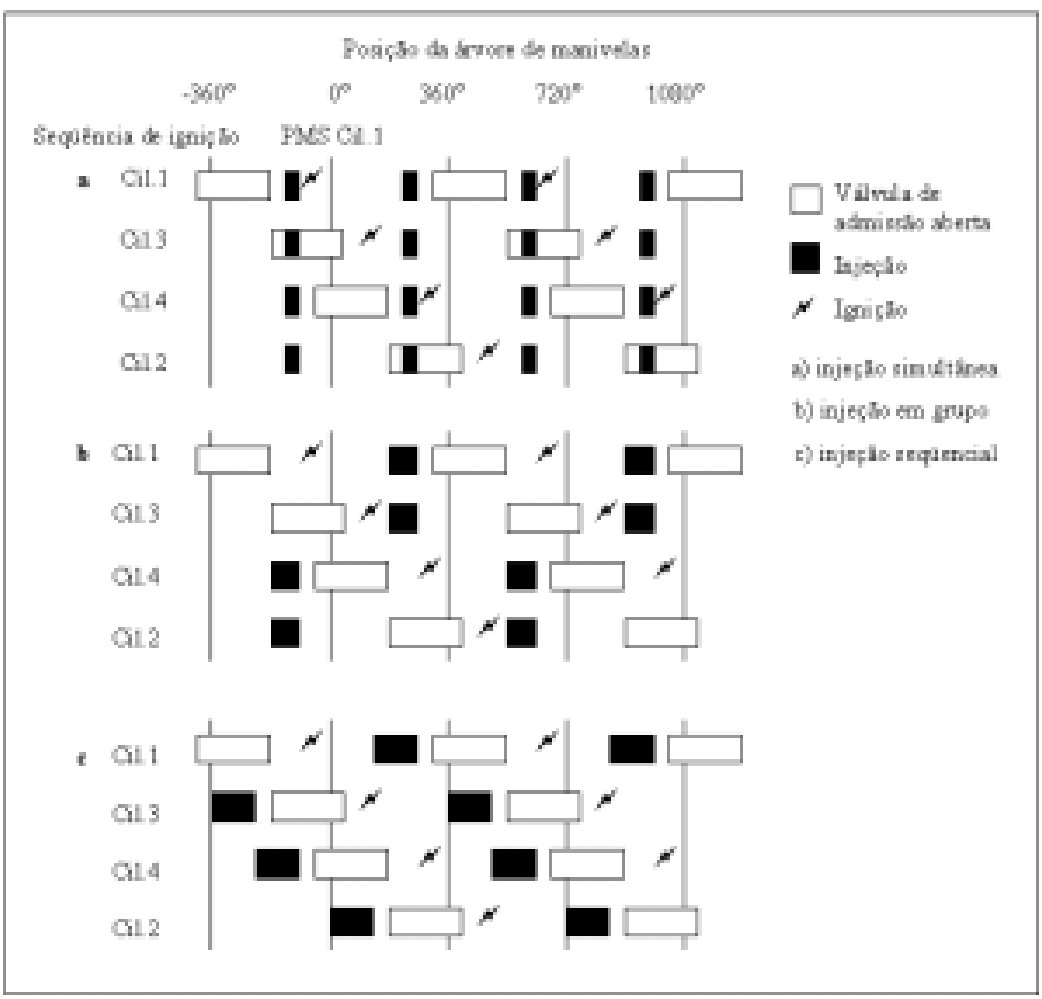

FIGURA 11 - Comparação entre os tipos de injeção. [BOSCH (1998), p. 39, fig. 2]

\subsubsection{Controle eletrônico da ignição}

O controle eletrônico da ignição trabalha a partir do mapa de avanço da ignição do motor. Uma vez detectada a condição de operação, as informações armazenadas nas tabelas são recuperadas corrigindo-se o ponto de ignição que é função da rotação do motor, pressão no coletor de admissão e temperatura do motor. Além de corrigir o ponto (ou ângulo) de ignição em função da condição de operação do motor, o controle eletrônico da ignição controla a ocorrência de knocking, de modo a atrasar o ponto de ignição quando o knock aparece. O ANEXO A descreve a atuação do controle da ignição nos diferentes modos de controle, segundo RIBBENS \& MANSOUR (1993). 


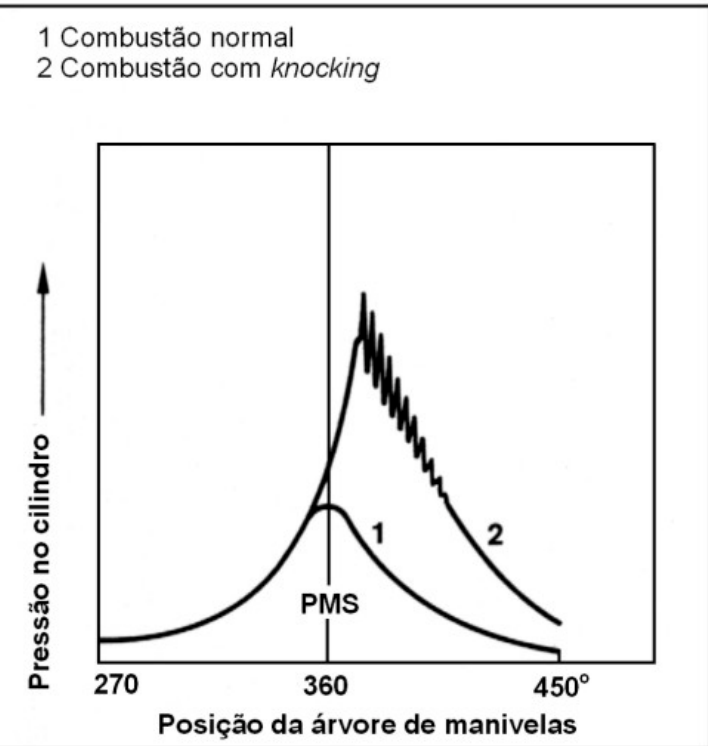

FIGURA 12 - Pressão de combustão com ocorrência de knocking. [BOSCH (1988), p. 162, fig. 27]

LENZ (1992), explica que o termo knocking ou pinking é utilizado para descrever a combustão com características muito próximas à combustão detonante, quando comparado com o processo normal de combustão. Esta forma de combustão é causada por reações espontâneas de oxidação em regiões quentes da carga (mistura ar-combustível) não queimada. Esta porção remanescente da carga é inicialmente comprimida pelo movimento do pistão e, em seguida, pelo movimento da frente de chama. A combustão caracterizada por knocking implica em ignição quase instantânea de parte da mistura remanescente, como mostra a FIGURA 12. Ocasionalmente, elevadas pressões localizadas, acompanhadas por ondas de choque e oscilações de pressão com um aumento da transferência de calor ocorrem, por conta deste indevido processo acelerado de combustão. Knocking pode causar alguns danos ao motor dependendo de sua intensidade e ocorrência. A ocorrência de knocking é influenciada pelas condições de operação do motor (fase de aquecimento, taxa de compressão, capacidade de dissipação térmica da mistura não queimada, ponto de ignição, etc.), pelo combustível utilizado e pela geometria da câmara de combustão (localização da vela de ignição, depósitos).

Como são vários os fatores que influenciam a ocorrência de knocking, BOSCH (1988) explica que, a adoção de uma margem de segurança para a definição do ponto de ignição, tal que, a não ocorrência de knocking esteja assegurada, acarretaria em elevado consumo de combustível. Isto pode ser evitado se os limites para o avanço da ignição forem determinados continuamente durante a operação do motor, ajustando o ponto em uma malha fechada pelo 
sensor $K S$, assumindo que o avanço especificado pelo mapa de avanço da ignição esteja na faixa de ocorrência de knocking.

A influência do ângulo de ignição na emissão de gases poluentes e no consumo específico de combustível pode ser vista nas FIGURA 04, FIGURA 05, FIGURA 06 e FIGURA 07.

O torque produzido pelo motor também depende do ponto de ignição. Com o aumento do ângulo, o torque aumenta até um determinado ponto em que este passa a diminuir com o adiantamento. O ponto de torque máximo é denominado de MBT.

\subsubsection{Controle da recirculação dos gases de escape}

O sistema de recirculação de gases de escape tem por função desviar uma parte dos gases queimados da tubulação de exaustão de volta para a admissão do motor, com o objetivo de diminuir a emissão de $N O_{X}$. Atuando como um gás inerte, o gás de exaustão provoca uma diminuição da temperatura de combustão com a conseqüente diminuição de $N O_{X}$ emitido ao meio ambiente. A quantidade de gás recirculado para a admissão varia em função da rotação do motor, pressão no coletor de admissão e temperatura do motor. $\mathrm{O}$ ANEXO A descreve a atuação do controle da recirculação dos gases de escape nos diferentes modos de controle, segundo RIBBENS \& MANSOUR (1993).

\subsubsection{Sensores}

Os sensores empregados nos motores de combustão interna são responsáveis pela informação das condições de funcionamento do motor à UCE. A descrição que segue, tem a finalidade de ilustrar, de maneira generalizada, as principais variáveis medidas para o gerenciamento dos motores e os sensores empregados. Variações do que será apresentado podem ocorrer em função do fabricante, levando-se em conta as especificações de cada projeto com relação ao custo e desempenho desejados.

\subsubsection{Sensores de pressão no coletor de admissão (MAP)}

O sensor de pressão no coletor de admissão, tem a função de informar as variações de pressão no coletor de admissão ou a pressão barométrica. Quando a estratégia rotaçãodensidade (speed-density), para o cálculo da massa de ar admitida pelo motor é utilizada, o sensor de pressão informa a pressão no coletor de admissão para que se possa calcular a densidade do ar. Em outros casos, a pressão no coletor é utilizada para se determinar a carga na qual o motor se encontra, de modo a definir o avanço da ignição, visto que este é uma função da rotação e da pressão do coletor. 
Em sistemas com medidores volumétricos, suscetíveis às variações da pressão atmosférica, o sensor de pressão é utilizado como um sensor de altitude, de modo a corrigir as variações de pressão atmosférica em função da altitude em que o veículo se encontra.

Dois tipos de sensores de pressão são mais freqüentemente utilizados, Strain Gage e Capacitivo.

Os sensores do tipo Strain Gage são formados por quatro elementos resistivos $\left(R_{1}, R_{2}\right.$, $R_{3}$ e $R_{4}$ ), os quais formam uma ponte de Wheatstone, como mostra a FIGURA 13. Montados em um diafragma de silício, como ilustra a FIGURA 14, tais resistores tem seus valores alterados devido à deformação do diafragma, causado pela variação de pressão no coletor de admissão. A tensão de saída do sensor varia linearmente com a pressão no coletor. Com relação aos elementos resistivos da ponte de Wheatstone, a tensão é dada pela eq. (4), onde $E_{e x}$ é uma tensão constante de alimentação.

$$
e_{A C}=\left(\frac{R_{1}}{R_{1}+R_{4}}-\frac{R_{2}}{R_{2}+R_{3}}\right) E_{e x}
$$

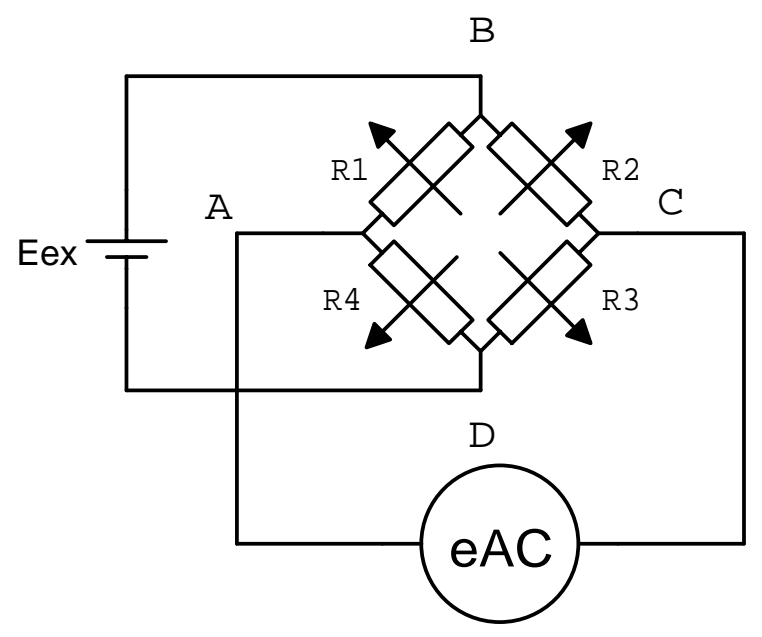

FIGURA 13 - Ponte de Wheatstone.

Os sensores do tipo capacitivo, baseiam-se no princípio de funcionamento de um capacitor. Constituído por duas placas condutoras paralelas e distantes entre si por uma distância $d$, e separadas por um elemento dielétrico, com constante dielétrica $\in_{0}$, a capacitância $C$ do capacitor varia de acordo com a eq. (5);

$$
C=\frac{\in_{0} A}{d}
$$

onde $A$, é a área da placa condutora. 


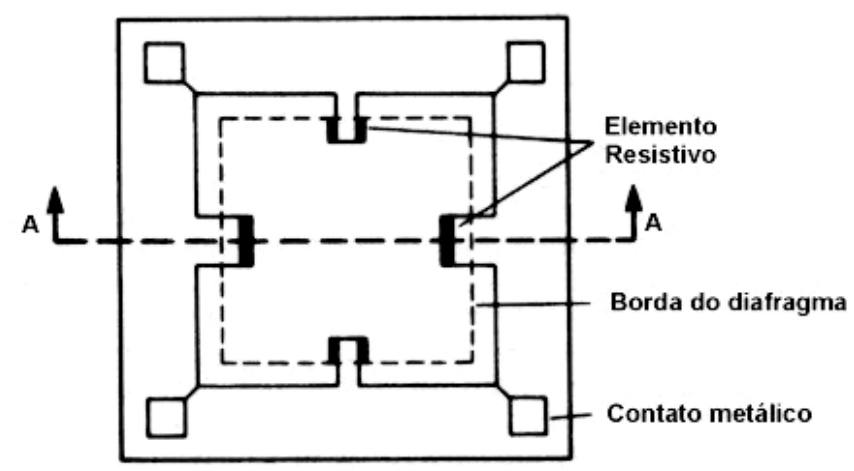

Vista Superior

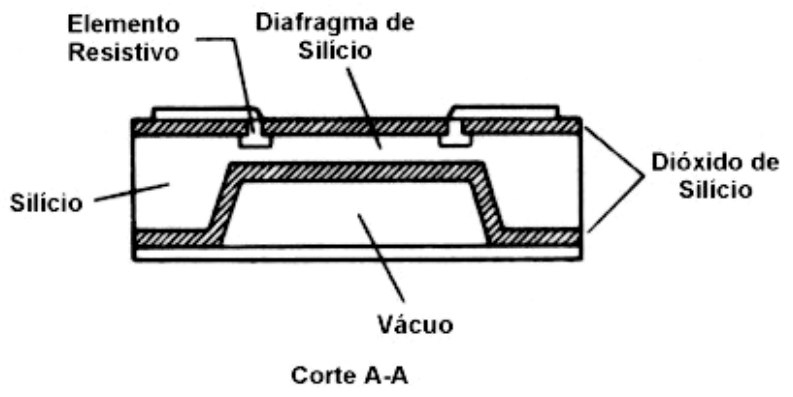

FIGURA 14 - Sensor de pressão do tipo Strain Gage. [RIBBENS (1993), p. 133, fig. 5.5.]

Os sensores de pressão do tipo capacitivos, são construídos de maneira que, a pressão que se deseja medir varie a distância $d$ entre as placas condutoras, fazendo com que a capacitância varie. Em aplicações automotivas, o sensor capacitivo faz parte de um circuito ressonante, cuja freqüência de oscilação varia em função da capacitância $C$. Desta forma a variação de pressão causará uma variação na frequiência do sinal recebido pela UCE.

\subsubsection{Sensores mássicos}

A medida direta da massa de ar que está sendo admitida pelo motor é realizada com a utilização de um elemento quente. Este elemento pode ser um fio ou um filme aquecido, dependendo da configuração do sensor. Nos sensores normalmente utilizados nos automóveis, o elemento quente deve permanecer a uma temperatura constante, entre $100^{\circ} \mathrm{e}$ $200^{\circ} \mathrm{C}$, acima da temperatura do ar. A medida que o ar passa pelo fio aquecido ou pela superfície do filme aquecido, ocorre uma troca de calor entre elemento quente e ar. Com a variação de temperatura do elemento quente, a corrente através deste precisa variar para que sua temperatura permaneça constante. A corrente necessária para que isso ocorra é uma medida da massa de ar que está sendo admitida pelo motor. O elemento quente faz parte de um circuito constituído de uma ponte de Wheatstone como mostra a FIGURA 15. Um outro elemento, uma resistência de compensação da temperatura, é inserido no sistema para que 
seja restabelecida a temperatura do elemento quente. Portanto, o sinal de saída do sensor, uma tensão, é diretamente proporcional à massa de ar que está sendo admitida pelo motor.

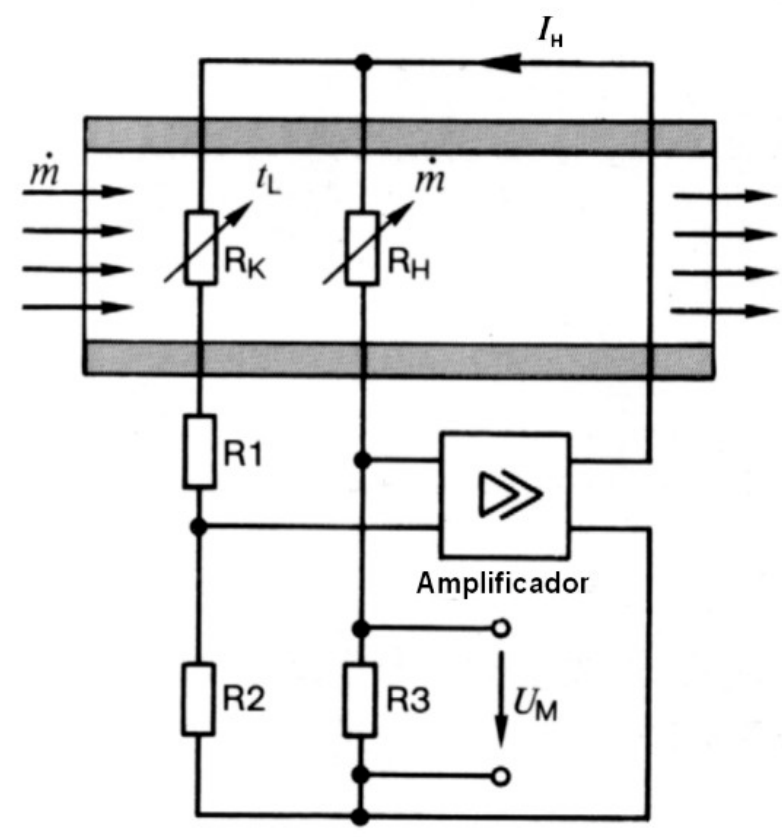

$m \quad$ Vazão de massa de ar

$\mathbf{R}_{\mathrm{H}} \quad$ Fio aquecido

$\mathbf{R}_{\mathbf{K}} \quad$ Sensor $\mathrm{p} /$ compensação

da temperatura

R1, R2 Resistores

R3 Resistor de medida

$\boldsymbol{U}_{\mathbf{M}} \quad$ Tensão de saída do sensor

$\boldsymbol{I}_{\mathrm{H}} \quad$ Corrente de aquecimento

$t_{\mathrm{L}} \quad$ Temperatura do ar

FIGURA 15 - Sensor de massa de ar. [BOSCH (1988), p. 257, fig. 36]

A vantagem da utilização deste tipo de sensor, reside no fato de oferecer baixa resistência à passagem do ar pela tubulação de admissão, não possuir elementos mecânicos em movimento e o cálculo da massa de combustível ser direto, não exigindo processamento devido à variações de altitude ou temperatura do ar.

Outra classe de sensores utilizada para se calcular a massa de ar admitida pelo motor, é a dos sensores volumétricos, os quais informam o fluxo volumétrico de ar. A utilização de tais sensores, torna necessária a determinação da densidade do ar (função da temperatura do ar e pressão barométrica), para então, calcular a massa de ar admitida. Esta classe de sensores não será detalhada aqui por ter uma pequena aplicação, se comparada aos sensores mássicos e a utilização do método rotação-velocidade com a utilização dos sensores de temperatura do ar e pressão no coletor de admissão.

\subsubsection{Sensores de posição da borboleta de aceleração}

A função destes sensores, é informar a posição angular da borboleta de aceleração, permitindo que a U.C.E. realize estratégias de controle de acordo com a TABELA 01. 
TABELA 01 - Estratégia em função da posição da borboleta de aceleração.

\begin{tabular}{|l|l|}
\hline \multicolumn{1}{|c|}{ Estado da borboleta de aceleração } & \multicolumn{1}{c|}{ Estratégia } \\
\hline \multirow{2}{*}{ Borboleta fechada } & Marcha lenta \\
\cline { 2 - 2 } & Cut-off* \\
\cline { 2 - 2 } & Dash-pot** \\
\hline Velocidade de abertura da borboleta & Aceleração rápida \\
\hline Borboleta totalmente aberta & Plena carga \\
\hline Borboleta parcialmente aberta & Carga parcial \\
\hline Ângulo da borboleta de aceleração & Definição do avanço da ignição*** \\
\hline
\end{tabular}

* Estratégia que corta a injeção de combustível durante as desacelerações (borboleta de aceleração fechada e rotação do motor alta);

** Estratégia utilizada para impedir a súbita queda de pressão no coletor de admissão durante as desacelerações, através do controle da quantidade de ar admitido;

*** Ângulo da borboleta é utilizado como sinal de carga para a determinação do avanço da ignição somente nos casos em que não se utiliza o sensor de pressão absoluta.

Diferentes tipos de sensores podem ser utilizados, como potenciômetro, potenciômetro de dupla pista e interruptor.

Os interruptores podem ser utilizados para o reconhecimento da condição de borboleta fechada, totalmente aberta, ou então, indicação de regime de marcha-lenta.

Os sensores do tipo potenciômetro, são fixados no corpo da borboleta, compartilhando o mesmo eixo. Um potenciômetro, formando um circuito divisor de tensão, determina o valor do ângulo de deflexão da borboleta, pela posição do cursor. O resultado é uma relação linear entre ângulo de abertura da borboleta e tensão de saída do sensor.

Nos casos em que o potenciômetro de dupla pista é empregado, uma das pistas é utilizada para o controle da marcha lenta. Esta pista tem um número maior de pontos relacionados à abertura da borboleta, ou seja, é mais precisa que a segunda pista, pois ambas fornecem a mesma faixa de tensão, mas a pista utilizada para o controle da marcha lenta, corresponde a um ângulo de abertura menor da borboleta.

\subsubsection{Sensores de temperatura}

Os sensores de temperatura são responsáveis por informar a temperatura do ar aspirado pelo motor e da água do sistema de arrefecimento, para a U.C.E.. Os dois tipos de sensores mais utilizados são NTC (Negative Temperatue Sensor) e PTC (Positive Temperature Sensor). A variação da temperatura provoca uma variação da resistência elétrica do elemento transdutor. No caso dos sensores do tipo NTC, a resistência elétrica diminui com o aumento da temperatura, ocorrendo o contrário nos sensores PTC, ou seja, a resistência aumenta com o aumento da temperatura. 
A informação da temperatura do ar é necessária para se determinar a densidade do ar, utilizada para o cálculo da massa de ar que está sendo admitida pelo motor.

Com relação à temperatura da água, esta informação é utilizada como indicativo da temperatura do motor servindo como parâmetro para que estratégias específicas possam ser realizadas, tais como:

$\checkmark$ Enriquecimento da mistura ar-combustível quando o motor estiver frio;

$\checkmark$ Cut-off com motor frio;

$\checkmark$ Controle da válvula EGR;

$\checkmark$ Substituição do sensor de temperatura do ar, caso este não seja empregado;

\subsubsection{Sensor de rotação do motor/PMS e sensores de fase}

Para que o sistema de injeção forneça a quantidade adequada de combustível e no momento certo, a UCE deve saber a rotação do motor e a posição de cada cilindro.

O sensor de rotação e PMS tem por finalidade gerar o sinal de rotação do motor e a posição da árvores de manivelas. Já o sensor de fase tem a função de, combinado com o sinal de rotação e PMS, permitir que a U.C.E. possa identificar o cilindro em ignição. Em casos específicos, no qual o sensor de fase está gerando o sinal sobre o mesmo eixo que o sensor de rotação, o sensor de fase permitirá a identificação do PMS. Em outros casos, o sensor de fase gera o sinal no eixo do comando de válvulas, o que permite a identificação do cilindro em ignição.

Tanto o sensor de rotação e PMS como o sensor de fase, podem ser baseado no princípio da relutância magnética (indutivo) ou efeito Hall.

Os sensores do tipo indutivo ou relutância magnética constituem-se de um encapsulamento contendo um imã permanente e um enrolamento elétrico de cobre (indutor) como pode ser visto na FIGURA 16. Seu princípio de funcionamento está baseado na força eletromotriz (f.e.m.) gerada devido à variação de fluxo magnético no indutor, provocada pela passagem dos dentes e cavidades da roda dentada, magnetizada, pelo sensor. A tensão gerada pelo sensor é proporcional à rotação da roda dentada. 


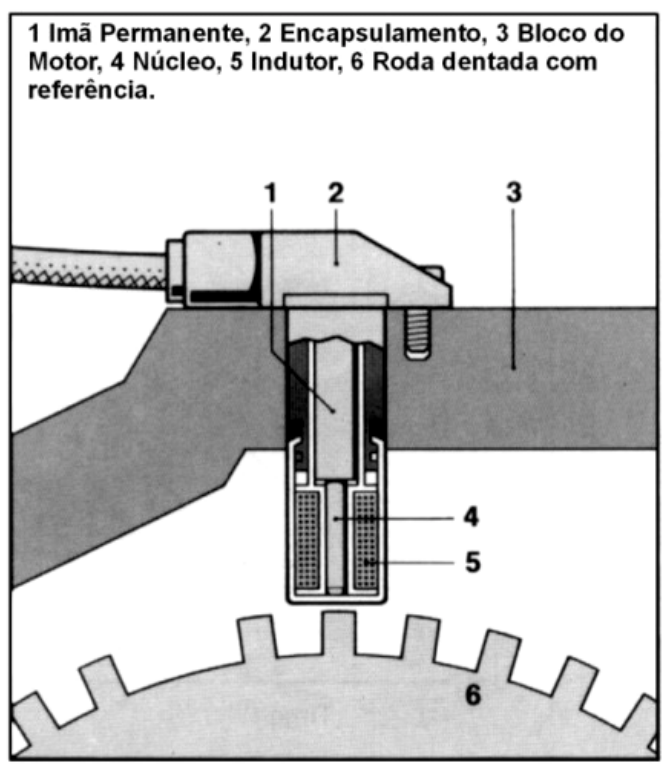

FIGURA 16 - Sensor de rotação tipo indutivo. [BOSCH (1988), p. 266, fig. 5]

Na FIGURA 17, pode-se observar uma placa condutora (Célula Hall) com propriedades magnéticas e de espessura $d$, sendo percorrida por uma corrente elétrica de controle $I$, e estando esta placa submetida perpendicularmente a um campo magnético $B$. O campo magnético gera um fenômeno chamado de efeito Hall, que consiste num desvio da corrente elétrica $I$ para um dos lados da placa, gerando uma diferença de potencial $V_{\mathrm{H}}$ (tensão Hall) em direção perpendicular, tanto à corrente $I$ como ao campo magnético. Na prática, o campo magnético é gerado por um imã permanente, a corrente elétrica $I$ por uma tensão $V_{\mathrm{V}}$ que deverá ser fornecida à placa condutora e a condição de circuito aberto e fechado é obtida por uma armadura em forma de um copo com janelas ao longo de seu perímetro, ou então, faz-se uso de uma roda dentada magnetizada, como no caso do sensor indutivo.

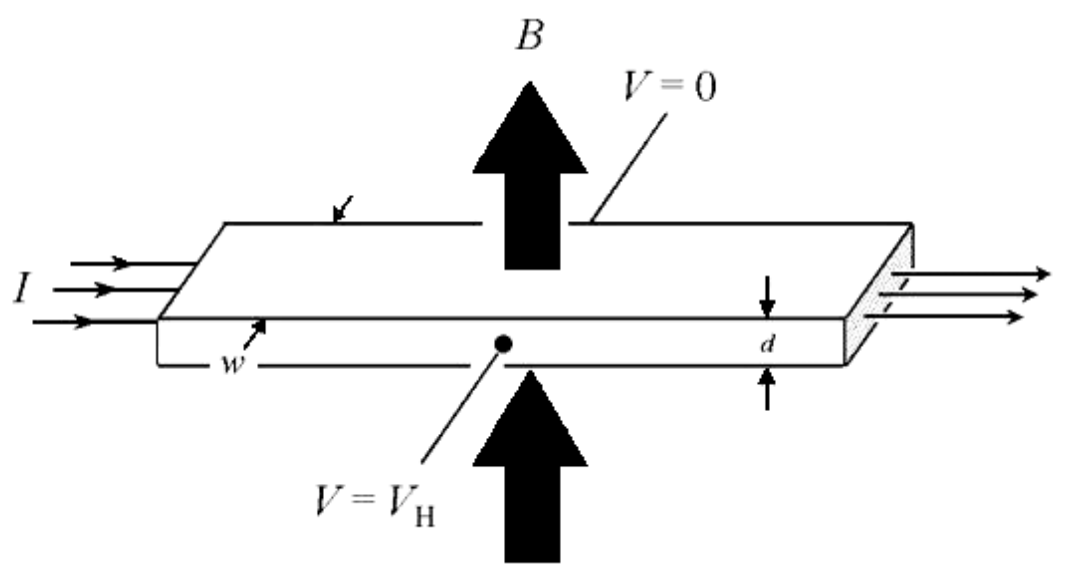

FIGURA 17 - Efeito Hall. 
Deve-se destacar que, nos sensores comerciais, composto por um circuito integrado, a tensão Hall passa por um circuito amplificador, antes de ser utilizado para o processo em questão, como mostra a FIGURA 18. No caso ilustrado, a tensão de 12 volts será obtida conectando-se um resistor entre a alimentação e o ponto de saída do sensor (saída em coletor aberto).

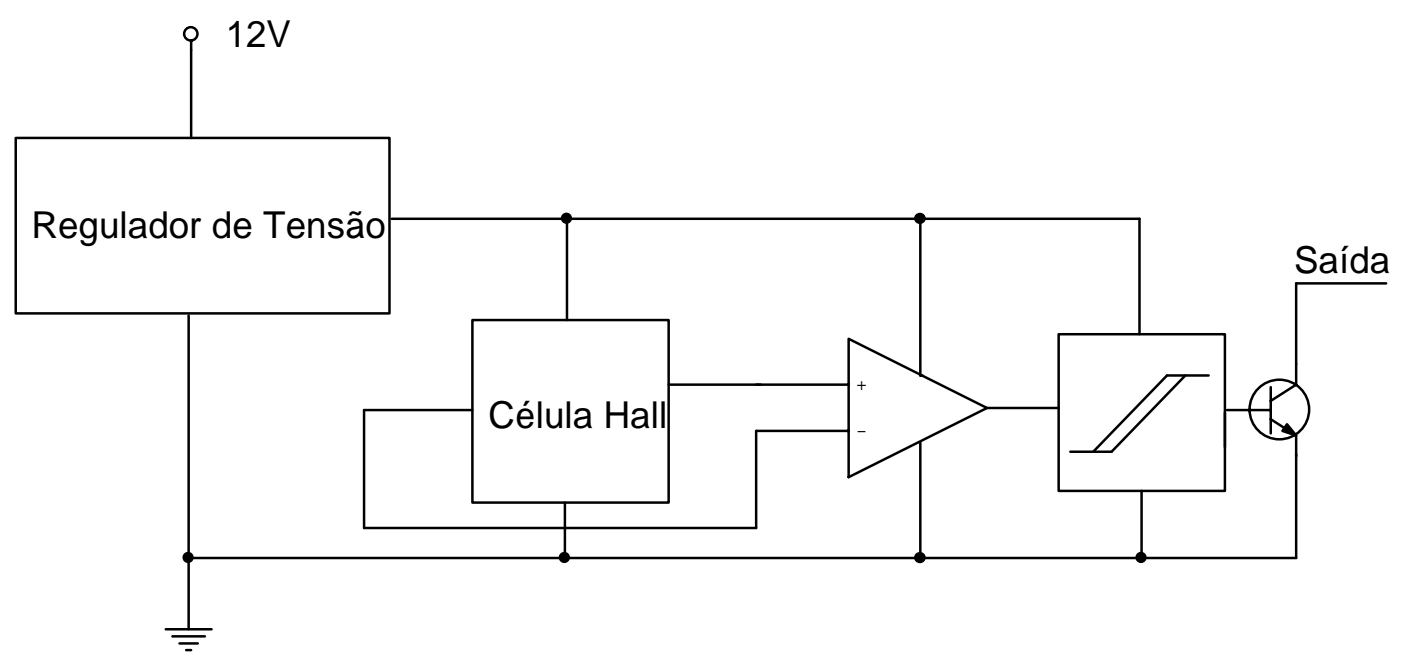

FIGURA 18 - Configuração interna de um circuito integrado Hall.

Várias configurações são utilizadas tanto para o sensor de rotação e PMS, como para o sensor de fase, incluindo diferentes tipos de rodas dentada.

\subsubsection{Sensor " $K S$ "}

O sensor KS (Knock sensor) consiste de um transdutor piezoelétrico e é responsável por enviar um sinal elétrico à U.C.E. para que esta reconheça a ocorrência do fenômeno knocking.

Determinados materiais, quando deformados, geram uma carga elétrica. Este efeito é reversível, ou seja, se uma carga elétrica é aplicada, o material se deformará mecanicamente. Estas ações são denominadas efeito piezoelétrico. (DOEBELIN, 1990, p. 261) 


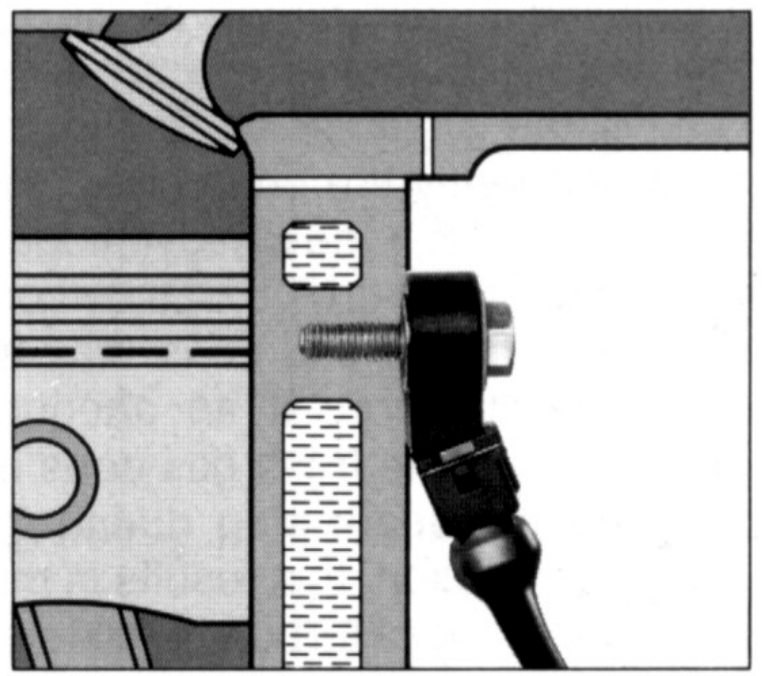

FIGURA 19 - Localização do sensor KS. [BOSCH (1988), p. 132, fig. 39]

O sensor $K S$ é arranjado de tal forma que a ocorrência de knocking em qualquer cilindro pode ser reconhecido sem dificuldade e em qualquer condição. A posição de montagem, é geralmente no lado do bloco do motor, como mostra a FIGURA 19.

Quando ocorre knocking, a freqüência de oscilação provocada pela combustão se iguala (casamento de freqüências) à freqüência característica do transdutor. A voltagem gerada é resultado da ressonância criada por este casamento de frequiências. A FIGURA 20, mostra o sinal de saída do sensor $K S$ (curva c), sem a ocorrência de knocking (1) e com a ocorrência de knocking (2). A curva a representa a pressão no cilindro, enquanto a curva b representa o sinal de pressão filtrado.

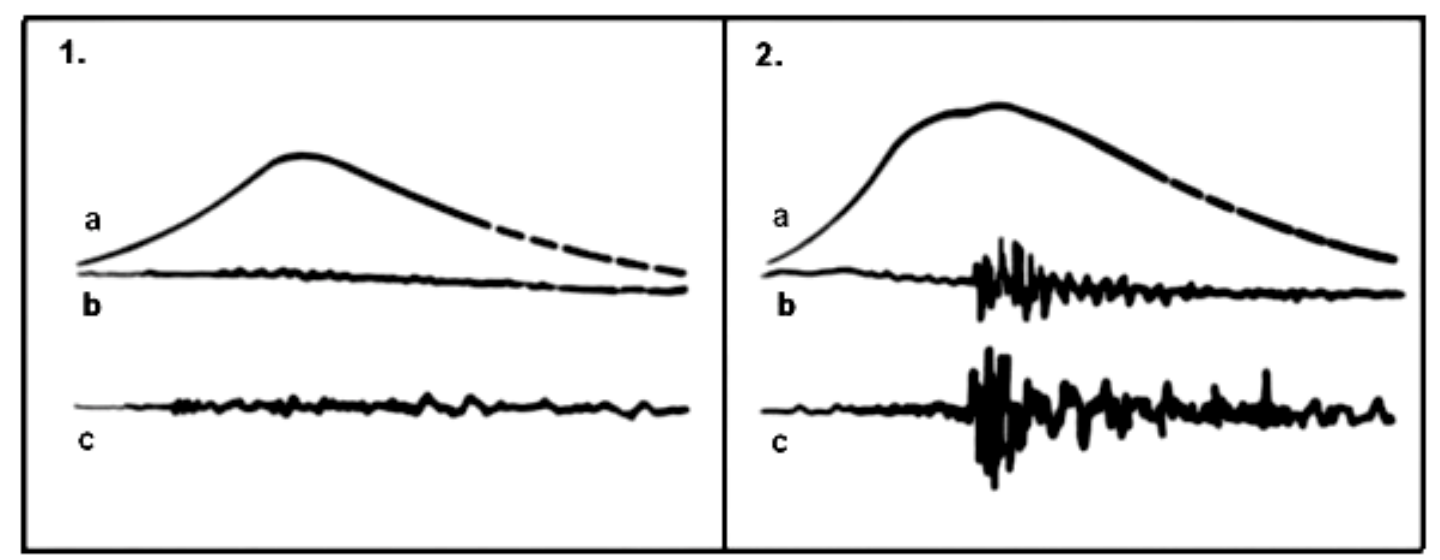

FIGURA 20 - Sinal do sensor $K S$. [BOSCH (1988), p. 133, fig. 40] 


\subsubsection{Atuadores}

Define-se atuadores como sendo todos os componentes do sistema de controle responsável por gerar uma ação sobre a planta, a partir de um sinal de controle. Nos sistemas de injeção eletrônica este sinal é de natureza elétrica (por exemplo, um pulso de tenção com largura variável), resultado do processamento realizado pela UCE. Nos modernos sistemas de controle dos motores de combustão interna, os atuadores podem variar tanto em número como em características construtivas. Neste trabalho serão descritos apenas os principais atuadores, aqueles que são empregados em praticamente todos os sistemas de controle de motores ciclo Otto.

\subsubsection{Válvulas eletromagnéticas injetoras de combustível (VEIC)}

As válvulas eletromagnéticas injetoras de combustível são dispositivos dosadores de combustível. Além deste tipo de atuador, outros componentes podem ser utilizados para esta função como carburador convencional e eletrônico, válvulas injetoras mecânicas, válvulas piezoelétricas, entre outros. As VEICs se tornaram o dispositivo mais utilizado, dentre os outros tipos de válvulas, devido às vantagens relacionadas à confiabilidade e ao custo. (PASSARINI, 1993, p. 1.38)

O princípio de funcionamento de uma VEIC se baseia na válvula solenóide. Os detalhes construtivos de uma VEIC típica podem ser observados na FIGURA 21.

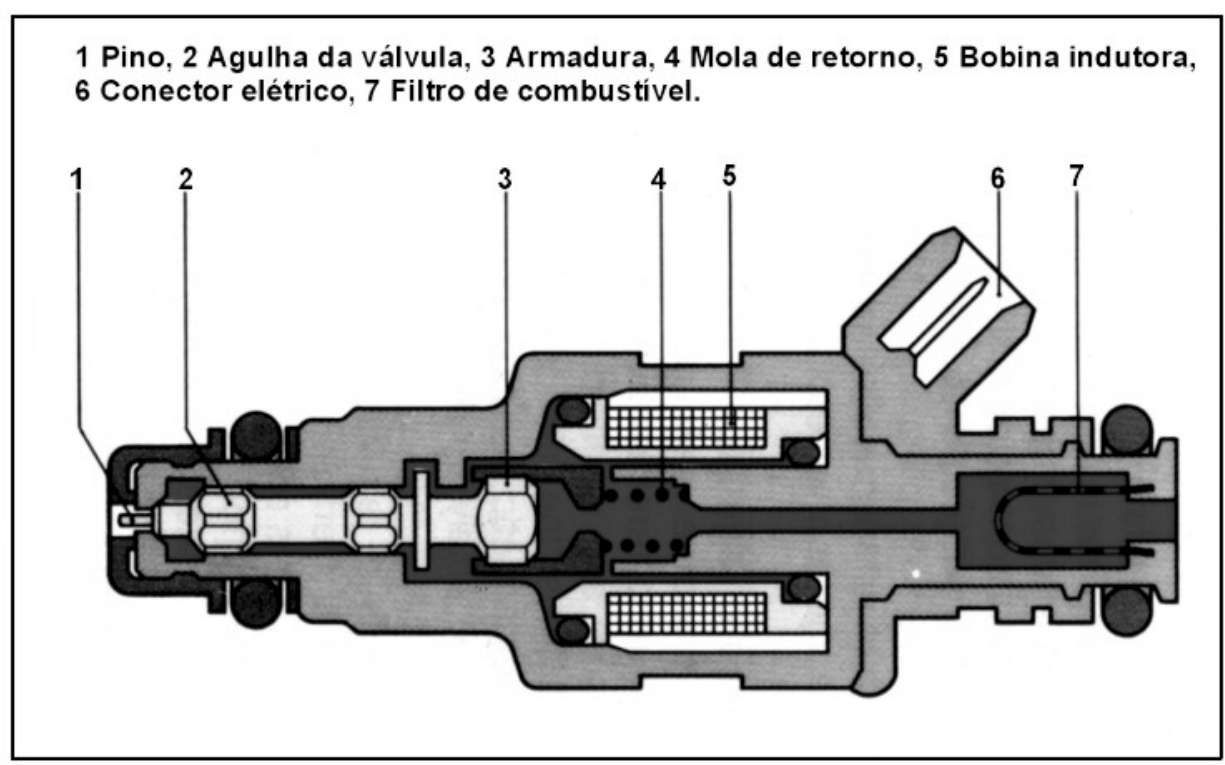

FIGURA 21 - Representação de uma válvula eletromagnética injetora de combustível. [BOSCH (1988), p. 236, fig. 8] 
Durante o estado de repouso, não há passagem de corrente pela bobina, não havendo portanto f.e.m., e desta forma, a mola de retorno pressiona o conjunto válvula-armadura contra o assento, não permitindo a passagem do combustível. Com a excitação pelo circuito de potência, a bobina é energizada deslocando o conjunto válvula-armadura no sentido de fechar o circuito magnético (deslocamento contrário à ação da mola) devido à f.e.m. gerada, abrindo a passagem para o combustível fluir. (BOSCH, 1988; PASSARINI 1993)

\subsubsection{Bobina de ignição}

A função da bobina de ignição é gerar a tensão alta requerida para provocar o centelhamento na vela de ignição ${ }^{11}$, cujo objetivo é iniciar o processo de combustão da mistura ar-combustível.

O funcionamento da bobina de ignição baseia-se na lei da indução, consistindo de dois enrolamentos de cobre acoplados magneticamente (enrolamento primário e secundário). A energia armazenada no enrolamento primário, por um sinal de baixa tensão, é transformado em um sinal de alta tensão na saída do secundário. A relação entre os sinais é função da relação do número de espiras entre os enrolamentos. Nos sistemas controlados eletronicamente, a energização e posterior corte do primário é realizado por um transistor, que atuando como uma chave, fecha o circuito de alimentação do primário até que se tenha energia suficiente para suprir a demanda. O período em que o primário é energizado (denominado de ângulo de permanência) é controlado, juntamente com o avanço, pelo sistema de controle da ignição. Geralmente a tensão fornecida pelo secundário é da ordem de $30 \mathrm{kV}$, garantindo assim, que a tensão de ruptura da vela de ignição seja alcançada e se tenha uma combustão eficiente.

"No momento da ignição, a tensão nos eletrodos da vela de ignição sobe abruptamente de zero até a tensão disruptiva (tensão de ignição). Lançada a faísca, a tensão na vela de ignição cai até a tensão de combustão. Durante o período de duração da faísca a mistura arcombustível tem a oportunidade de se inflamar. Após a ruptura da faísca a tensão se estabelece periodicamente como mostra a FIGURA 22." (BOSCH, 1998, p. 10)

\footnotetext{
${ }^{11}$ A vela de ignição é um dispositivo que, instalado na câmara de combustão de cada cilindro, gera uma centelha (ou faísca) entre seus eletrodos, quando se aplica a alta tensão do secundário da bobina de ignição.
} 


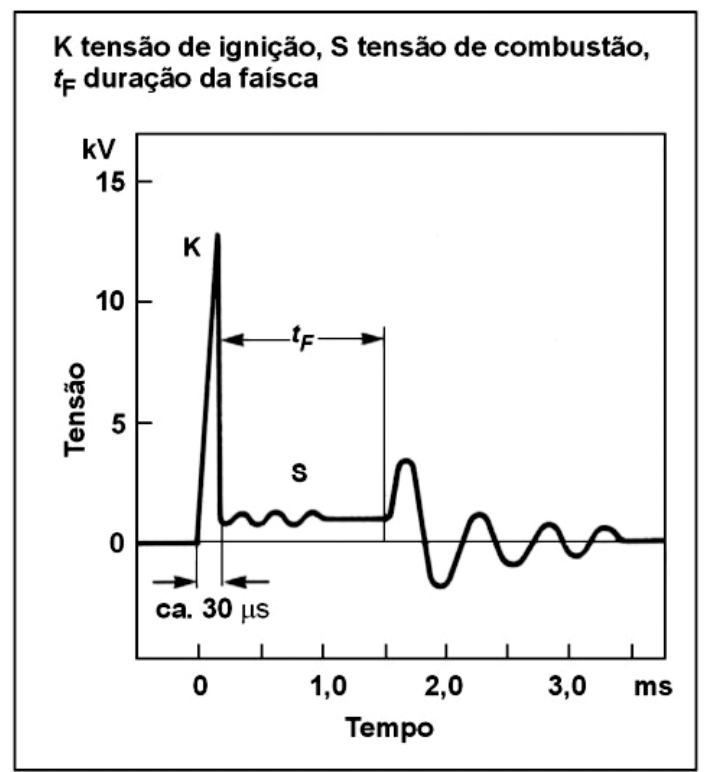

FIGURA 22 - Tensão na vela de ignição. [BOSCH (1988), p. 141, fig. 2]

São aplicadas diferentes configurações quanto à forma de se transmitir o sinal do secundário às velas de ignição e ao número de bobinas disponíveis, tais como, bobina simples com distribuidor de tensão (distribuição rotativa), bobina de ignição com uma saída de tensão para cada cilindro (distribuição estática) entre outras. (BOSCH, 1998)

\subsubsection{Corretor da marcha lenta}

O controle da marcha lenta visa manter a rotação do motor o mais estável possível, quando o pedal do acelerador não está sendo acionado e a rotação do motor é baixa, fazendo a compensação necessária na mistura ar-combustível e no avanço da ignição, estando o motor frio, quente, ou sob uma demanda de carga como o ar condicionado.

Existem duas maneiras de se realizar o controle da mistura ar-combustível durante a marcha lenta. Uma delas é regulando a passagem de ar por um by-pass, permitido que o ar seja admitido mesmo quando a borboleta de aceleração esteja completamente fechada. Outra maneira é através do controle da abertura da borboleta de aceleração. (não se deve confundir com Drive-by-wire).

No primeiro caso, costuma-se utilizar um motor de passo, cujo eixo contém um obturador. De acordo com a estratégia de controle, o motor de passo recua ou avança permitindo a passagem de mais ar ou menos ar pelo by-pass, com o objetivo de manter a rotação estável. Já no segundo caso, geralmente, um motor de corrente contínua (motor DC) é utilizado. Atuando sobre o eixo da borboleta de aceleração, o motor DC abre ou fecha parcialmente a borboleta de aceleração a partir de um sinal com largura de pulso modulada 
(PWM) e com inversão de polaridade. O motor DC tem a possibilidade de abrir a borboleta de aceleração até $20^{\circ}$ aproximadamente.

Além de controlar a quantidade de ar para estabilização da marcha lenta, o corretor da marcha lenta também executa a função Dash-pot durante as desacelerações.

Outros atuadores, além dos descritos anteriormente, podem ser utilizados em um sistema de gerenciamento de motores a combustão interna como válvula EGR, válvula de purga do canister e outros mais, que não serão descritos por não serem relevantes para o desenvolvimento deste trabalho.

\subsubsection{Tratamento do gás de exaustão}

\subsubsection{Controle em malha fechada através da sonda lambda}

O controle em malha fechada através da sonda lambda, em conjunto com o conversor catalítico, é o mais eficiente método de purificação dos gases de exaustão dos motores ICE disponível atualmente, não havendo ainda, outra alternativa capaz de obter algo próximo ao mesmo nível de emissão.

Operando em conjunto, os sistemas de injeção e ignição permitem obter níveis muito baixos de emissão de gases poluentes. No entanto, uma redução adicional, particularmente dos componentes prejudiciais, hidrocarbonetos não queimados, monóxido de carbono e óxidos de nitrogênio, pode ser obtida se um conversor catalítico for usado. O conversor catalítico de três estágios pode reduzir a emissão de $H C, C O$ e $N O_{X}$ em mais de $90 \%$, se o motor estiver sendo operado em uma faixa muito estreita em torno da mistura ar-combustível estequiométrica $(\lambda=1 \pm 0,5 \%)$, como mostra a FIGURA 23. Este pequeno desvio, só pode ser mantido pelos modernos sistemas de injeção de combustível, controlados eletronicamente. Por essa razão, utiliza-se o controle em malha fechada com sonda lambda, ou seja, a composição da mistura ar-combustível é continuamente mantida dentro da faixa ótima, pelo controle em malha fechada. Para isso, a exaustão deve ser medida e a quantidade de combustível injetada, imediatamente corrigida, em função da medida realizada. A sonda lambda é utilizada como o sensor de realimentação. Esta gera uma tensão de ruptura exatamente em $\lambda=1$, fornecendo portanto, um sinal que mostra o quanto a mistura desvia do valor estequiométrico. 


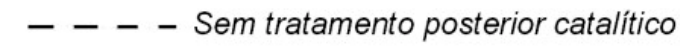

Com tratamento posterior catalítico

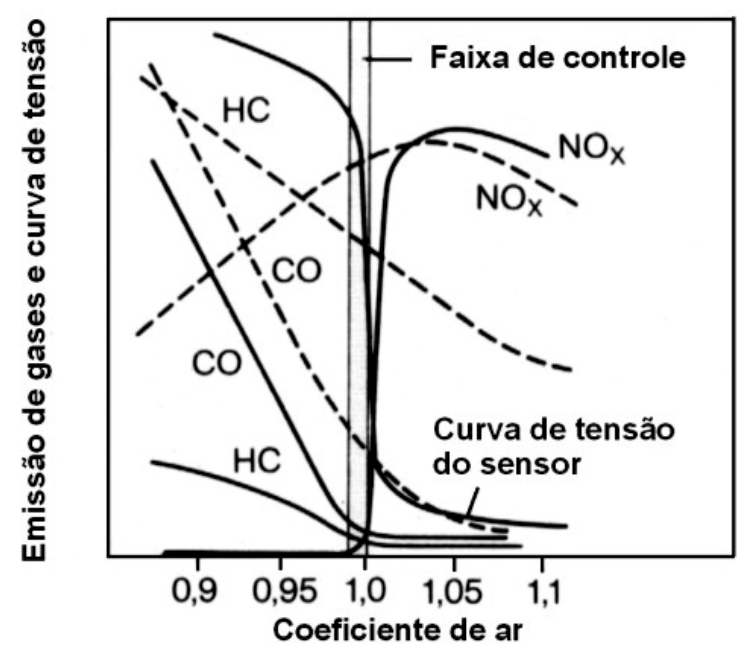

FIGURA 23 - Faixa de controle da sonda lambda e redução da concentração de poluentes na exaustão. [BOSCH (1995), p. 18, fig. 1]

O sensor de oxigênio (ou sonda lambda) mede no tubo de exaustão, de maneira uniforme, o fluxo de exaustão de todos os cilindros. O método de operação é baseado no princípio de uma célula galvânica para concentração de oxigênio com eletrólito de estado sólido.

\section{Construção}

O eletrólito de estado sólido consiste de um corpo cerâmico compacto fechado em uma das extremidades. É construído com dióxido de zircônio e estabilizado com óxido de ítrio. As faces têm eletrodos em ambos os lados feitos de uma fina camada de platina permeável a gás.

O eletrodo de platina, no lado de fora, age como um pequeno conversor catalítico onde a exaustão é submetida ao tratamento catalítico conduzindo ao equilíbrio estequiométrico. No lado exposto ao gás de exaustão, há uma camada de cerâmica porosa (spinell layer) o qual atua como uma proteção contra a contaminação. Um tubo de metal com uma determinado número de fendas protege o corpo cerâmico contra choques mecânicos e térmicos. $\mathrm{O}$ espaço aberto interno está em contato com o ar atmosférico, o qual atua como um gás de referência.

A FIGURA 24, representa uma sonda lambda instalada na tubo de exaustão. 


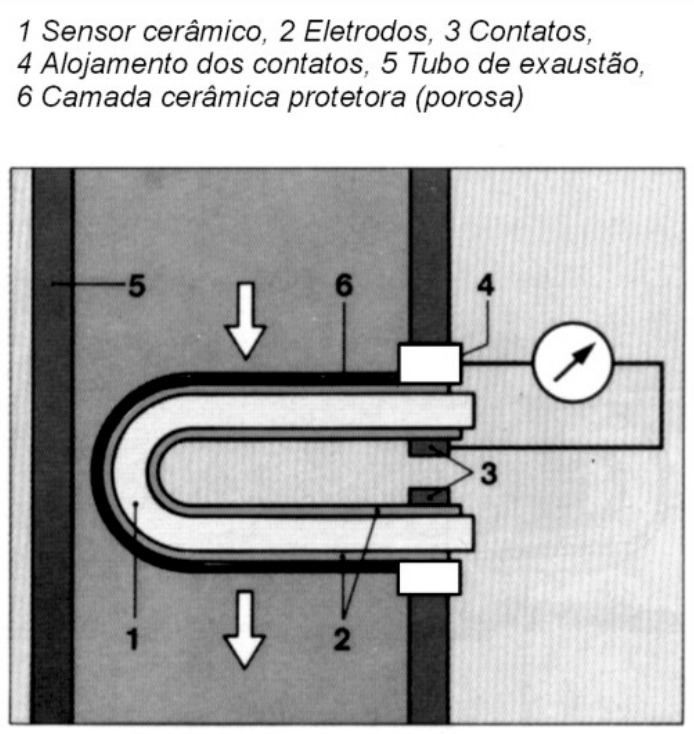

FIGURA 24 - Representação da sonda lambda. [BOSCH (1995), p. 227, fig. 14]

\section{Método de operação}

O material cerâmico usado pelo sensor, se torna condutor a uma temperatura de $350^{\circ} \mathrm{C}$.

Se a concentração de oxigênio for diferente entre os dois lados do sensor, será gerada uma tensão elétrica entre os eletrodos, servindo como uma medida da diferença na concentração de ar entre os dois lados do sensor. A quantidade de oxigênio remanescente na exaustão de um motor a combustão interna é fortemente dependente da relação ar-combustível na mistura fornecida ao motor. Desta forma, com excesso de ar na mistura, restará uma determinada concentração de oxigênio na exaustão; por exemplo, $\operatorname{com} \lambda=0,95$, restará entre 0,2 a $0,3 \%$ de oxigênio em volume. A partir desta relação, torna-se possível o uso da concentração de oxigênio na exaustão como uma medida da razão ar-combustível. A voltagem fornecida pela sonda lambda como resultado da concentração de oxigênio na exaustão, atinge valores entre 800 a $1000 \mathrm{mV}$ com mistura rica $(\lambda<1)$, mas fica em torno de $100 \mathrm{mV}$ com mistura pobre $(\lambda>1)$. A transição entre a faixa pobre e a rica permanece entre 450 e $500 \mathrm{mV}$, como mostra a FIGURA 25.

Além da concentração de oxigênio na exaustão, a temperatura do corpo cerâmico, também é um fator importante, uma vez que esta influencia a condutividade dos ions de oxigênio. Assim, a curva de tensão elétrica fornecida como uma função de $\lambda$ (curva "estática" do sensor) é fortemente influenciada pela temperatura. Além disso, o tempo de resposta para uma mudança de voltagem devido à uma alteração na composição da mistura, também depende da temperatura. Ao passo que, o tempo de resposta, estando a cerâmica à 
uma temperatura abaixo de $350^{\circ} \mathrm{C}$, é da ordem de segundos, em condições de temperatura ideal de operação, em torno de $600^{\circ} \mathrm{C}$, o sensor responde em menos $50 \mathrm{~ms}$. Por isso, o controle em malha fechada através da sonda lambda, passa a ser ativado somente quando se atinge a temperatura mínima de operação do sensor, ou seja, por volta de $350^{\circ} \mathrm{C}$. Até este ponto, o motor opera com controle em malha aberta.

a) Mistura rica (deficiência de ar)

b) Mistura pobre (excesso de ar)

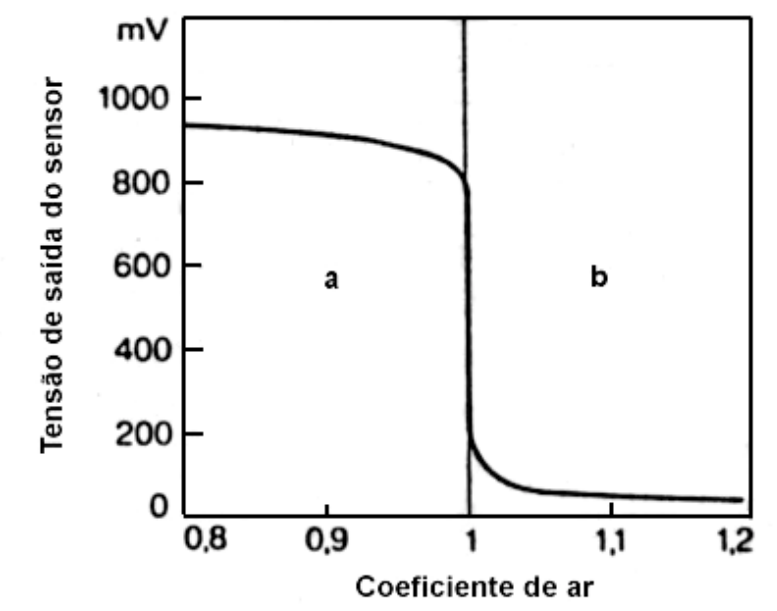

FIGURA 25 - Curva característica de uma sonda lambda operando a uma temperatura de $600^{\circ} \mathrm{C}$. [BOSCH (1995), p. 227, fig. 15]

\section{Sonda lambda aquecida}

Com este sensor, a temperatura da cerâmica, em condições de carga baixa do motor (baixa temperatura da exaustão), é determinada por um aquecedor elétrico, já em condições de carga elevada, o aquecimento da cerâmica é determinado pela temperatura da exaustão. A sonda lambda com aquecimento pode ser instalada à uma grande distância do motor, de modo que, o problema de diminuição da vida útil do sensor, devido à exposição a elevadas temperaturas e por períodos longos, deixa de existir. Com o aquecimento interno, a sonda tem um aquecimento mais rápido, de modo que, de 20 a 30 segundos após o início de funcionamento do motor, a temperatura de operação já será alcançada e o controle em malha fechada ativado. Pelo fato de que, a sonda com aquecimento, sempre está operando na temperatura ideal, pode-se alcançar e manter um baixo nível de emissão por mais tempo. Desde que se tenham corretas condições de operação, a sonda lambda aquecida pode ter sua vida útil além dos $100000 \mathrm{~km}$. Porém, a fim de se evitar danos, o motor deve ser operado com combustível livre de chumbo. 


\subsubsection{Tratamento posterior catalítico}

Dentre os sistemas catalíticos desenvolvidos e aplicados na indústria automobilística, o que obteve melhores resultados com relação à eliminação dos gases poluentes da exaustão dos motores de combustão interna, e que é largamente utilizado, é o conversor catalítico de três estágios. Este tipo de conversor remove, simultaneamente, os três gases poluentes $C O$, $H C$ e $N O_{X}$, em mais de $90 \%$, como pode ser observado na FIGURA 23. Um pré-requisito é que a mistura ar-combustível fornecida ao motor, e portanto, a exaustão deva estar na proporção estequiométrica, como descrito anteriormente. A função do catalisador, ou conversor catalítico, é promover a pós combustão do $\mathrm{CO}$ e $\mathrm{HC}$, transformando-os em $\mathrm{CO}_{2} \mathrm{e}$ vapor d'água, e decompondo, ao mesmo tempo, $N O_{X}$ em Nitrogênio $(N)$.

\section{Substratos}

O conversor catalítico consiste de um invólucro metálico, um substrato e uma camada catalítica ativa.

Segundo BOSCH (1995), existem três diferentes tipos de substrato:

\section{Pellet}

Este tipo de substrato, ilustrado na FIGURA 26, foi utilizado principalmente no Japão e EUA, mas seu emprego está diminuindo, sendo que já não é mais empregado na Europa.

\section{Cerâmica monolítica}

São corpos cerâmicos perfurados por milhares de pequenos canais, através dos quais o gás de escape flui, como mostra a FIGURA 26. O material cerâmico é silicato de magnésioalumínio com elevada resistência à temperatura. O monolítico, que é extremamente sensível à tensões mecânicas, é montado em um invólucro metálico. Entre as paredes do invólucro e o substrato, tem-se uma malha metálica elástica, feita de uma liga de fio metálico com diâmetro de aproximadamente $0,25 \mathrm{~mm}$. Este tipo de substrato é o mais utilizado.

\section{Metálico monolítico}

Este tipo de substrato é raramente utilizado. Conversores com este substrato são empregados principalmente como pré catalisadores, sendo instalado mais próximo do motor, e têm a função de suprir o conversor principal, com o intuito de se obter uma conversão catalítica mais rápida após partidas a frio. Sua aplicação como catalisador principal torna-se inviável devido ao custo elevado, se comparado com catalisadores com substrato cerâmico monolítico. 


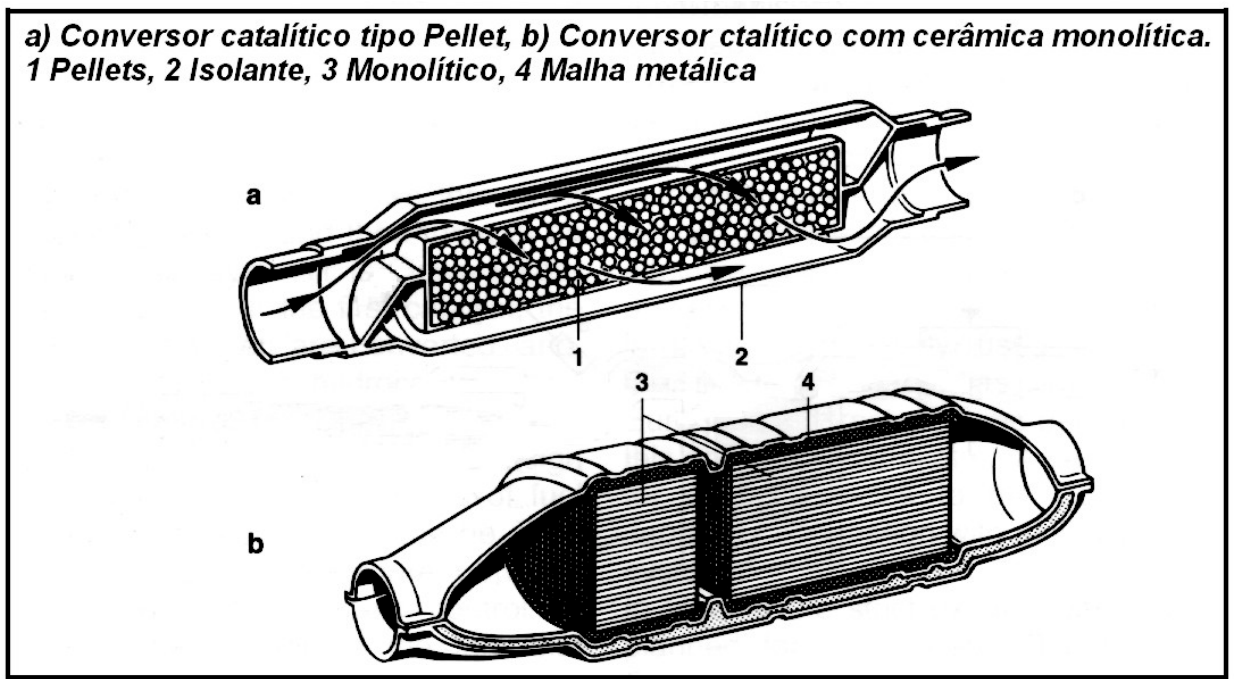

FIGURA 26 - Tipos de substratos. [Bosch (1995), p. 24, fig. 8]

\section{Cobertura}

Enquanto o substrato tipo pellet pode ser coberto diretamente com a substância catalisadora, cerâmico e metálico monolítico requerem uma cobertura de óxido de alumínio, a qual aumenta a área efetiva do catalisador por um fator de aproximadamente 7000. A cobertura catalítica efetiva, aplicada sobre essas, consiste de catalisadores oxidantes de metais nobre como platina e paládio ou platina e ródio nos catalisadores de três estágios. Platina acelera a oxidação de hidrocarbonetos e monóxido de carbono, e o ródio acelera a redução de óxido de nitrogênio. O conteúdo de metais nobres em um catalisador é de aproximadamente 2 a 3 gramas.

\section{Condições de operação}

Como no caso da sonda lambda, a temperatura de operação, também ó muito importante para o funcionamento do conversor. A conversão dos poluentes se torna apreciável somente a uma temperatura de operação superior a $250^{\circ} \mathrm{C}$. A condição de operação ideal para se ter uma alta taxa de conversão e vida útil longa requer temperaturas na faixa de $400^{\circ} \mathrm{C}$ a $800^{\circ} \mathrm{C}$. Entre $800^{\circ} \mathrm{C}$ e $1000^{\circ} \mathrm{C}$, a fadiga térmica é bastante agravada, levando à redução da área da superfície ativa. Portanto, nesta faixa de temperatura, a duração da operação exerce uma grande influência. Acima dos $1000^{\circ} \mathrm{C}$, a fadiga térmica aumenta severamente, levando à ineficiência total do catalisador. Esta característica limita as possibilidades de instalação. 


\subsection{SISTEMAS FUTUROS}

A preocupação com o nível de emissões continuará sendo o incentivo principal para o desenvolvimento de sistemas mais eficazes de gerenciamento de motores, pois as legislações estarão cada vez mais rigorosas no que diz respeito à emissão de poluentes nos próximos anos. Desta forma, algumas linhas de pesquisa e desenvolvimento, como segue descrição, serão responsáveis pela evolução dos sistemas futuros.

\subsubsection{Novos sistemas catalíticos}

Conforme KISHI et al. (2000), pesquisas estão em andamento para o desenvolvimento de sistemas catalíticos híbridos com aquecimento elétrico, o que reduz o tempo de aquecimento dos catalisadores, aumentando o período de atuação, principalmente durante a fase de aquecimento do motor, onde se tem elevada emissão de hidrocarbonetos e o conversor ainda não está na temperatura de operação.

Diminuir o tempo de aquecimento dos conversores catalíticos é uma preocupação da maioria dos fabricantes, visto que, grande parte da emissão dos gases poluentes, principalmente $H C$, ocorre nos primeiros momentos de funcionamento do motor, quando o controle está atuando em malha aberta e o conversor catalítico não atingiu a temperatura mínima de operação.

Segundo SHELEF \& MCCABE (2000), as pesquisas e desenvolvimentos relacionados aos conversores catalíticos estarão relacionadas à redução de $N O_{X}$ em misturas pobre, desenvolvimento de conversores que atuem mesmo na presença de enxofre (considerado elemento contaminante), eficiência catalítica em toda a faixa de temperatura do gás de exaustão, diminuição da temperatura mínima para o início de operação, entre outros.

\subsubsection{Novas estratégias de controle}

A partir das novas estratégias, o controle será baseado na modelagem dinâmica dos motores (MBC - model-based controller), diferentemente da forma em que os sistemas atuais trabalham (calibração). Com isso, espera-se que o controle seja mais preciso, tornando possível a diminuição do consumo de combustível e do nível de emissões de gases poluentes, além do aumento do desempenho do motor.

CHANG et al. (1995), a partir da modelagem por espaço de estados da dinâmica do sistema de dosagem da mistura ar-combustível (considerando a dinâmica do ar e do combustível no coletor de admissão, o atraso cíclico devido aos quatro tempos do motor e o atraso no transporte da mistura queimada para fluir da válvula de escape até a posição do 
sensor de oxigênio) e aplicando a metodologia de estimador de estados, implementou um controlador para a mistura ar-combustível em um motor de um cilindro. Utilizando tanto sensor linear, para a medida de $O_{2}$ na exaustão, como a sonda lambda convencional, bons resultados foram obtidos no controle da mistura ar-combustível, mostrando que o sistema é capaz de suprir os problemas relacionado ao atraso entre a formação da mistura na admissão e a medida da relação ar-combustível na exaustão, característico dos motores C.I.. Além disso, a eficiência do conversor catalítico pôde ser maximizada.

Como já foi visto na seção 3.3.6.1, com a utilização dos conversores TWC, torna-se necessário manter a mistura ar-combustível em uma faixa em torno da mistura estequiométrica, com desvio de $\pm 0,5 \%$, onde o catalisador de três vias tem a maior eficiência. Os sistemas de controle convencionais são capazes de manter a mistura nesta faixa, desde que o motor esteja operando em regime permanente. Mas em períodos transitórios, como nas acelerações, torna-se difícil manter a mistura na faixa de maior eficiência do catalisador, o que resulta em um aumento na emissão dos gases poluentes. MATSUMARA \& NANYOSHI ${ }^{*}$ apud TAKAGI et al. (1998), explicam que a dificuldade está relacionada ao fato de o balanço entre a adesão e a evaporação do combustível injetado, nas paredes do coletor de admissão, se desbalanceia nos estados transitórios. Além disso, a intensidade deste desbalanceamento varia de acordo com as condições de operação do motor, ou seja, é não linear. As alterações causadas pelas mudanças nas condições de operação são variáveis no tempo. Assim, TAKAGI et al. (1998), realizaram estudos para se melhorar a exaustão nos períodos transitórios utilizando redes neurais. Optou-se pela utilização das redes neurais por se adequarem à não linearidade e pelo recurso de backpropagation, aplicado para resolver os problemas relacionados às características de variação temporal. Como resultado, obteve-se um decréscimo de $33 \%$ na emissão de $N O_{X}$ ao se adicionar a rede neural ao sistema convencional de realimentação pelo sensor de $O_{2}$. Além disso, passou a ser possível a adaptação à mudanças nas características físicas do controlador (hardware) e nas características do motor com a técnica de aprendizado aplicada à rede.

BALLUCHI et al. (1999), propuseram um controlador tal que, aplicado à um motor com sistema multiponto de injeção de combustível (MPFI) e com controle eletrônico da abertura da borboleta (DBW), fosse capaz de liberar o torque exigido, o mais rápido possível, mantendo a mistura ar-combustível próxima do valor estequiométrico. O modelo utilizado envolve desde as características elétricas do motor de acionamento da borboleta de

\footnotetext{
* MATSUMARA, T.; NANYOSHI, Y. New fuel metering techinique for compensating wall flow in a transiente condition using the model-matching method. JSAE Review, v.10, n.3.
} 
aceleração até as características dinâmicas da parte mecânica do motor. Uma particularidade deste trabalho está no fato de se utilizar uma modelagem híbrida para a geração de torque pelos cilindros do motor e para o processo de injeção. Os autores consideraram os quatro tempos de um ciclo, exaustão, admissão, compressão e expansão; além dos eventos ocorridos durante as fases de admissão e exaustão relacionando o posicionamento das válvulas de admissão e escape, caracterizando-os estados discretos na modelagem do sistema. Embora os autores apresentaram os resultados gerados em simulações, não há dados comparativos com um sistema convencional para se verificar a validade do controle aqui aplicado. Mas segundo os autores, tal abordagem é capaz de resolver o problema de manter a mistura ar-combustível próxima da razão estequiométrica ao se liberar, o mais rápido possível, o torque exigido.

KAWAI et al. (1999), objetivando um controle mais preciso da mistura ar-combustível para se atingir emissão ultra baixa nos veículos automotivos, aplicaram a técnica de estimadores em conjunto com um regulador auto adaptativo. A partir da modelagem do comportamento dinâmico dos gases de escape na exaustão e da modelagem do sensor linear para a medida da razão ar-combustível, a técnica de estimadores foi utilizada para se controlar a mistura ar-combustível em cada um dos cilindros do motor. Como resultado, a variação na mistura entre os cilindros foi eliminada, tornando possível manter a mistura de todos os cilindros na razão desejada. Além do estimador, um regulador auto adaptativo foi empregado para manter a mistura ar combustível desejada mesmo em condições transientes, como na abertura da válvula do canister, na recirculação dos gases de escape, e nas acelerações e desacelerações, além de, eliminar os efeitos dos distúrbios do motor. Com uma maior precisão no controle da relação ar-combustível, obteve-se uma melhora significativa na eficiência do conversor catalítico utilizado.

Outra preocupação no gerenciamento dos motores a combustão interna está relacionada com a marcha lenta, período em que a borboleta de aceleração não está sendo acionada pelo motorista e o motor está operando em baixa rotação.

Segundo ABATE et al. (1994), nestas condições, deseja-se que a rotação seja a mínima e a mistura ar-combustível pobre, o que resulta em baixo consumo de combustível. Porém, em baixas rotações, a dinâmica de formação da mistura ar-combustível é prejudicada, o que faz com que o motor apresente uma menor estabilidade, aumentando a susceptibilidade aos distúrbios, como acionamento do ar condicionado, aumento na pressão da direção hidráulica, acionamento da primeira marcha na caixa de engrenagens, entre outros, o que causa um aumento no torque exigido na árvore de manivelas, resultando em oscilações na rotação do motor, o que pode até causar a parada deste. Cabe portanto ao sistema de gerenciamento 
minimizar as variações na rotação (preestabelecida) do motor, durante a marcha lenta, devido à dinâmica de formação da mistura e aos distúrbios no torque exigido.

HERMAN \& FRANCHEK (2000), propuseram o controle da marcha lenta com saturação do atuador. Neste caso, o controle da marcha lenta é realizado por uma válvula de ar secundário. Normalmente a válvula de ar secundário é utilizada em conjunto com o avanço da ignição. Com isso, consegue-se tanto uma boa regulagem da rotação do motor como total rejeição de distúrbios. Mas se levar em conta a regulamentação de emissão dos gases poluentes, a atuação do avanço é atenuada. Portanto os autores focaram a investigação apenas no controle pela válvula de ar secundário. Considerando a dinâmica da planta e do distúrbio (distúrbio externo em forma de degrau) e as especificações de desempenho da saída (variação na rotação em relação ao valor pré estabelecido), intensidade de saturação do atuador e estabilidade, um controlador robusto foi projetado no domínio da freqüência, facilitando o projeto do sistema com incertezas paramétricas e atrasos (características marcantes na modelagem de um motor C.I.). O distúrbio foi considerado como sendo um torque resultante do acionamento da bomba da direção hidráulica e a saturação considerada na tensão de acionamento da válvula de ar secundário. Os resultados obtidos tanto em simulação como na implementação atingiram um nível de desempenho superior ao que se obtém com o controle linear.

STOTSKY; EDGARDT \& ERIKSSON (1999), propuseram um novo controlador para a borboleta de aceleração e a ignição com o intuito de se regular a rotação em regime de marcha lenta sob distúrbios desconhecidos e variantes no tempo, levando-se em conta o atraso entre a admissão e a produção do torque resultante, através de um modelo de segunda ordem e não linear do motor. O estimador projetado para estimar os distúrbios desconhecidos permite que o limite superior do erro seja arbitrariamente pequeno. A lei de controle foi projetada de forma que a borboleta de aceleração é utilizada para a produção do torque, enquanto que, a ignição é utilizada tanto para compensar o atraso entre a admissão e o torque resultante, como para compensar os erros do estimador de distúrbios. A lei de controle visa manter o avanço da ignição no ponto MBT (máximo torque), se a rotação do motor estiver próxima do desejado e não houver a necessidade de uma ação de controle rápida.

THORNHILL et al. (2000), compararam diferentes métodos para o controle da marcha lenta em um motor com sistema MPFI. No motor em questão, a marcha lenta é controlada pela válvula de ar secundária (acionada por um motor de passo) e pelo controle da ignição. Os métodos de controle testados estão listados abaixo e, segundo os autores, possuem as seguintes características: 
Controle proporcional mais integral (PI): controle padrão em produção;

Lógica Difusa $(L D)$ : capaz de controlar sistemas não lineares;

Lógica Difusa Adaptativa (LDA): capaz de controlar sistemas não lineares variantes no tempo;

Lógica Difusa Adaptativa com prognóstico de Smith (LDAS): capaz de controlar sistemas não lineares, variantes no tempo e com atrasos;

Controle por Matriz Dinâmica (CMD): capaz de controlar sistemas com atraso;

As simulações e ensaios realizados, objetivaram a análise da eficácia de cada método de controle com relação à regulagem da rotação em marcha lenta, à rejeição de distúrbios conhecidos e à entrada e saída do regime de marcha lenta.

Nas simulações, o controle com LD, o controle com LDAS e o CMD, mostraram bons resultados com o avanço da ignição constante sendo que o controle com matriz dinâmica apresentou os melhores resultados, pois apresenta uma ótima relação entre planta e modelo. O controle PI e o controle com LDA mostraram-se instáveis nas simulações.

Nos ensaios realizados com o motor, não foi possível implementar os algoritmos para o controle com LDAS e para CMD. Mantendo-se o avanço da ignição constante, o controle PI apresentou estabilidade marginal, ao passo que o controle LDA instável e somente o controle com LD apresentou resultado satisfatório. Já nos ensaios realizados com o controle proporcional da ignição, os três métodos apresentaram-se estáveis e o melhor resultado foi obtido com o controle LDA. Nos ensaios para verificação da rejeição de distúrbios, apenas o controle com LD foi utilizado. Mantendo-se a ignição constante a $10^{\circ}$ antes do ponto morto superior, o controle com LD apresentou boas características de rejeição de distúrbio e habilidade para seguir um valor pré determinado da rotação. Os ensaios para verificação de entrada/saída do regime de marcha lenta não foram conclusivos pois a válvula de ar secundário não estava se reajustando, sendo que o esforço de controle estava sendo exercido apenas pela malha do avanço da ignição.

Como conclusão final, ficou evidente que o controle convencional da marcha lenta pode ser melhorado com a utilização de novos métodos de controle. Com isso uma economia significativa de combustível e uma marcha lenta mais estável pode ser obtida por exemplo com um controlador com LD, já que este é capaz de regular a rotação em marcha lenta mantendo o avanço da ignição constante, podendo ser ajustado para o ponto MBT. 


\subsubsection{Otimização de sistemas mecânicos}

Como pôde ser observado, vários dos trabalhos citados anteriormente, utilizam motores com sistema eletrônico de controle da borboleta de aceleração (DBW). Isso mostra uma outra tendência no que diz respeito à otimização dos motores C.I.. Sistemas que eram puramente mecânicos, passaram a ser controlados eletronicamente, como é o caso da borboleta de aceleração, com a utilização do sistema DBW, o comando de válvulas que passou a ser variável e controlado eletronicamente, o coletor de admissão que, em alguns motores passou a ter sua geometria variada e assistida pelo controle eletrônico e por fim, motores com sistemas turbo-compressores, com tais sistemas controlados pela UCE, principalmente por motivos de integridade do motor, controlando eventuais sobrecargas.

O sistema DBW é o mais utilizado comercialmente dentre os sistemas citados anteriormente. ROSSI, TILLI \& TONIELLI (2000), explicam que surgiu com o propósito de integrar o gerenciamento do ar, combustível e da ignição. A arquitetura DBW não requer nenhum tipo de ligação direta entre o pedal do acelerador e a borboleta de aceleração. A borboleta é acionada por um motor elétrico controlado por um sistema eletrônico cuja função é a de mediar entre a solicitação do motorista, interpretado por um sensor de posição do pedal de aceleração, e possibilidade efetiva de tração, dependente da dirigibilidade, segurança e restrições no limite de emissões. Há uma série de funções que podem ser obtidas ou melhoradas com o controle da posição da borboleta em um sistema DBW como regulagem da marcha lenta e gerenciamento da partida a frio, regulagem da marcha lenta em condições transientes, controle automático da velocidade do veículo, controle de tração, integração com transmissão automática, entre outros.

Com relação ao comando de válvulas variável (VCT), BOSCH (1995), explica que este pode influenciar o motor C.I. de várias maneiras:

$\checkmark$ Elevado torque, baixa emissão e consumo de combustível;

$\checkmark$ Controle da composição da mistura;

$\checkmark$ Graduado ou infinitamente variável ajuste da admissão e exaustão;

STEFANOPOULOU; FREUDENBERG \& GRIZZLE (2000), a partir da análise da interferência de um comando de válvulas variável no funcionamento de um motor, projetaram um controlador baseado em um modelo capaz de coordenar o comando de válvulas variável e o sistema de injeção de combustível em um motor C.I., a fim de se reduzir o nível de emissão de gases poluentes $\left(H C\right.$ e $\left.N O_{X}\right)$, regular a mistura ar-combustível em torno do ponto estequiométrico e manter a resposta do torque similar a um motor 
convencional, ou seja, com comando de válvulas fixo. Segundo os autores, a otimização e o controle em tempo real de um VCT em um motor equipado com duplo fasor do comando de válvulas pode reduzir potencialmente a emissão de $H C$ e $N O_{X}$, retardando-se o tempo do comando, pois os produtos da combustão que seriam expelidos durante a fase de exaustão, são retidos no cilindro durante a subseqüente admissão. A contribuição deste diluente na mistura no cilindro reduz a emissão de $H C$ e $N O_{X}$. Por outro lado, a porção diluente afeta a carga de ar que está sendo admitida, alterando portanto, a resposta do torque e agindo como um distúrbio na malha de controle da mistura ar-combustível. O efeito do VCT na resposta do torque é indesejável devido à questões de dirigibilidade. Além disso, o efeito do VCT na mistura ar-combustível é indesejável devido à possível degradação da eficiência do conversor catalítico. A partir desta análise o controlador foi projetado de forma a seguir um valor desejado para a fase do comando de válvulas, de modo a se obter a melhor relação entre a emissão de poluentes e o torque de saída tanto em condições de marcha lenta, carga parcial e carga total (WOT). Uma comparação entre duas arquiteturas de controle, multivariável e descentralizada, mostrou que, um controle multivariável não se faz necessário, visto que, o controle descentralizado apresenta resultados tão satisfatórios quanto os apresentados pelo multivariável e, além disso, a implementação de um VCT em um motor convencional se faz mais fácil, pois não requer o desenvolvimento completo de um novo programa de controle e procedimentos de calibração.

A obediência à legislação de gases poluentes é o que tem alimentado o desenvolvimento do controle dos motores C.I.. A julgar pelos índices de gases poluentes adotados para os próximos anos, a tendência do controle eletrônico dos motores C.I. aponta para a utilização de novas estratégias de controle, baseadas em MBC, utilizando técnicas bem mais poderosas, como controle auto adaptativo, redes neurais e lógica difusa. Consequentemente, haverá um abandono das técnicas baseadas em tabelas, montadas a partir do processo de calibração, partindo para a utilização de algoritmos mais complexos baseados em equações dinâmicas. Estas novas estratégias exigirão UCE mais potentes exigindo a utilização de processadores de 32-bits e, possivelmente, a substituição da arquitetura CISC pela RISC, além da utilização de sensores mais precisos e inteligentes, comunicando-se entre si, via rede. Isto viabilizará a aplicação dos novos conceitos aqui apresentados para que as legislações governamentais possam ser cumpridas mantendo-se o desempenho e a dirigibilidade dos veículos automotores. 


\section{METODOLOGIA}

\subsection{INTRODUÇÃO}

O sistema de controle desenvolvido neste trabalho, constitui um sistema eletrônico aberto para o controle de um motor de combustão interna ciclo Otto, flexível o bastante para que estratégias de controle possam ser testadas e implementadas para fins de pesquisa, possibilitando a realização de experimentos relacionados tanto à área de sistemas de controle (aplicação de novas técnicas de controle, aquisição de dados e desenvolvimento de novos componentes, como sensores e atuadores), bem como às pesquisas que estejam relacionadas aos processos termodinâmicos do motor.

Para tanto, a escolha do processador, principal componente de todo o sistema a ser implementado, deve seguir a tendência mundial no que diz respeito à capacidade de processamento. Além disso, devido à característica de "ferramenta de desenvolvimento" atribuída ao sistema, sua programação deve ser realizada através de uma linguagem de programação intermediária para se ter flexibilidade em se tratando de desenvolvimento de hardware e software. A linguagem ANSI C, cumpre este requisito e é tida como padrão em aplicações desse tipo.

Outra característica a ser levada em consideração durante o desenvolvimento do sistema, é a necessidade de se controlar diferentes motores, o que exige uma boa versatilidade dos sistemas de aquisição de sinais e de interface com os atuadores, com uma certa flexibilidade para o controle de diferentes motores.

Neste capítulo, serão descritos todos os módulos do sistema que constituem o hardware projetado, ou seja, a unidade central de processamento, com as principais características do microcontrolador utilizado, o sistema de aquisição de sinais, e os sistemas de potência para acionamento das VEICs, acionamento do corretor da marcha lenta e acionamento do estágio de potência da bobina de ignição. Além disso, faz-se uma descrição do software gerado para a realização de testes do sistema. 


\subsection{DESCRIÇÃO DO HARDWARE}

A seguir, serão descritas as principais características do hardware desenvolvido.

\subsubsection{Unidade Central de Processamento}

Define-se unidade central de processamento, o conjunto microcontrolador, memórias e barramento para comunicação de dados. O microcontrolador e as memórias fazem parte de um kit de desenvolvimento, construído e comercializado pela ARM. A ARM é uma empresa cuja atividade está relacionada ao fornecimento de soluções baseadas em microprocessadores de 16/32-bits com arquitetura RISC. O modelo aqui utilizado é o KPI0041A, cujas principais características são:

\footnotetext{
$\checkmark$ Microcontrolador SHARP LH77790A

$\checkmark \quad$ 128K de memória FLASH EEPROM e dois blocos de 64K x 8 de SRAM

$\checkmark$ Conector JTAG para interface com LH77790A

$\checkmark$ Porta serial RS232 para comunicação com Host PC

$\checkmark$ Regulador de tensão de 5V (LM2937ES)
}

Características do microcontrolador ${ }^{12}$ :

$\checkmark \quad$ Freqüência de $25 \mathrm{MHz}$ a $5 \mathrm{~V}$ e $16,7 \mathrm{MHz}$ a $3,3 \mathrm{~V}$

$\checkmark$ Arquitetura ARM7DI RISC de 32-bits

$\checkmark$ Duto de endereço externo de 26-bits

$\checkmark$ Duto de dados externo de 16-bits

$\checkmark$ Cache de dados/instrução de $2 \mathrm{~KB}$

$\checkmark$ SRAM de $2 \mathrm{~KB}$

$\checkmark$ Três canais PWM (resolução de 8 e 16-bits)

$\checkmark$ Três canais counter/timer de 16-bits (compatível com 82C54)

$\checkmark$ Três portas paralelas (PA, PB, PC) de 8-bits programável (compatível com 8255)

além de outras características.

12 Para mais detalhes, consultar LH77790A/B Embedded Microcontroler - User's Guide e ARM7TDMI Data Sheet. 
A memória FLASH EEPROM é utilizada para armazenar o programa de controle, enquanto o conjunto de memórias SRAM, pode ser utilizado para armazenas parâmetros tais como, curvas de avanço, tempo de injeção e etc.

O programa de controle é carregado na FLASH a partir de um código fonte gerado e compilado em um computador pessoal (Host PC), via comunicação serial, como mostra a FIGURA 27.

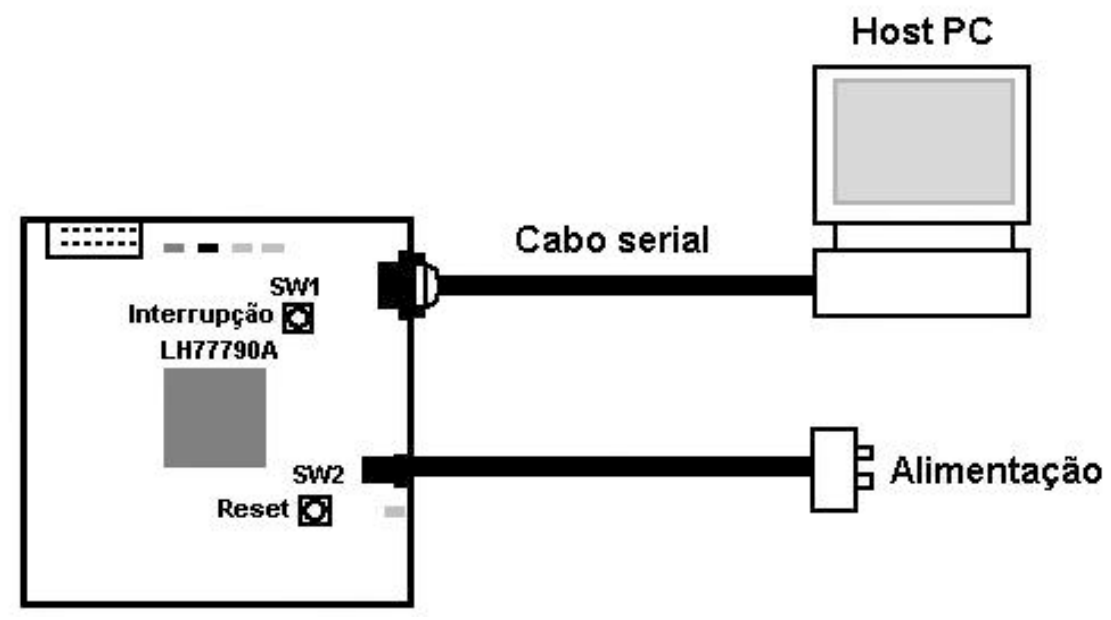

FIGURA 27 - Sistema KPI-0041A conectado a um microcomputador. [ARM Evaluation Board (1998), p. 3-3, fig. 3-1]

\subsubsection{Sistemas de aquisição de sinais}

Como foi visto no item 3.3 controle eletrônico dos motores, para o gerenciamento de um motor ciclo Otto, é necessário a medida de várias grandezas, as quais definem a condição de funcionamento do motor e a correspondente ação de controle. Dentre as várias grandezas medidas (pressão, temperatura, posição angular entre outras), é necessário que a unidade de comando seja capaz de fazer aquisição tanto de sinais analógicos como sinais digitais. Desta forma, o sistema desenvolvido, permite a aquisição tanto de sinais analógicos, como sinais digitais.

\subsubsection{Sinais analógicos}

Através do sistema de aquisição de sinais analógicos é possível adquirir sinais de todos os sensores cuja saída seja um sinal analógico na forma de tensão ou corrente. Este sistema é composto por dois conversores A/D de 12-bits. Cada conversor possui 6 canais diferenciais possibilitando a leitura simultânea em todos os canais. O sistema possui 6 entradas diferenciais para leitura de tensão e 6 para leitura de corrente. 


\subsubsection{Sinais digitais}

Os circuitos de interface para os sinais digitais, são responsáveis por condicionarem o sinal recebido pelo sistema de forma a atenuar a amplitude do sinal para que este seja interpretado pelo microcontrolador como nível lógico 0 (zero) ou 1 (um), além de servir como proteção ao duto de dados do microcontrolador. O sistema projetado possui dois tipos de entradas digitais.

Para a leitura de sinais gerados por sensores de efeito Hall ou indutivo, existem duas entradas com threshold de 10V, ou seja, o nível lógico 1 (5V TTL) na saída do circuito corresponde a uma tensão de no mínimo $10 \mathrm{~V}$ na entrada do circuito. A FIGURA 28, representa a interface projetada para sinais deste tipo.

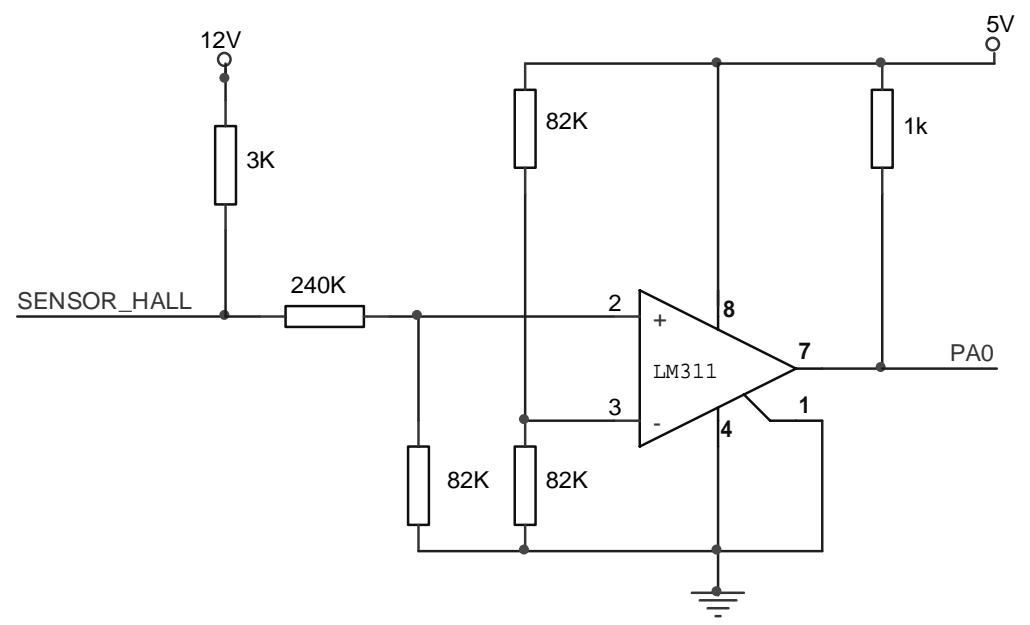

FIGURA 28 - Interface para aquisição do sinal do sensor Hall.

Para a leitura de sinais gerados por interruptores, foi projetado uma entrada de 0 a $5 \mathrm{~V}$ (5V representa nível lógico 1). Sinais gerados por interruptores, geralmente, apresentam ruído quando ocorre o chaveamento, o que pode prejudicar a aquisição destes sinais. Neste caso deve-se atentar para que o ruído do interruptor seja eliminado. A FIGURA 29, representa o circuito cuja função é eliminar o ruído do sinal e proteger o duto de dados do microcontrolador contra tensões elevadas.

Todas as entradas digitais são conectadas à porta paralela $\mathrm{A}(\mathrm{PA})$ do microcontrolador como mostra o ANEXO B. 


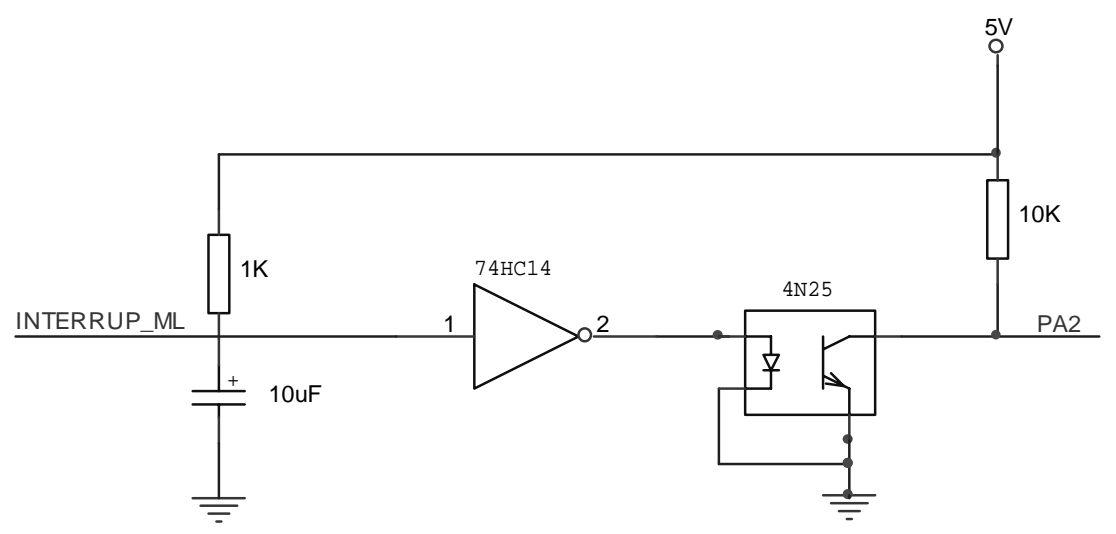

FIGURA 29 - Interface para interruptores.

\subsubsection{Circuitos elétricos de potência}

Os circuitos elétricos de potência, condicionam os sinais provenientes da unidade central de processamento antes de serem enviados para os atuadores. Os sinais disponíveis nesta configuração são aqueles para o acionamento das VEICs, sinal para acionar o estágio de potência da bobina de ignição (energização da bobina) e um sinal para atuar no corretor de marcha lenta.

\subsubsection{Circuito de potência para acionamento das VEICs}

Os meios de acionamento das VEICs podem ser através da excitação por tensão (surto de tensão) ou excitação por corrente (surto de corrente).

Os circuitos elétricos de potência mais utilizados para acionamento das VEICs são de excitação por tensão. De acordo com PASSARINI (1993), neste tipo de circuito, um transistor de potência é utilizado como uma chave, sendo excitado por uma corrente em sua base. Assim, na presença da corrente excitadora, o transistor se fecha fazendo com que a VEIC seja excitada por uma corrente gerada devido ao potencial aplicado pela bateria e, consequentemente, se abre para a passagem do combustível. Sem a corrente excitadora na base, o transistor se abre e a VEIC se fecha.

Além dos circuitos de excitação por tensão, utiliza-se circuitos de potência com excitação por corrente. Neste tipo de circuito, faz-se um controle da corrente que excitará a VEIC. Para que esta abra de maneira mais eficiente, uma corrente de pico, $i_{\mathrm{PK}}$, é gerada, fazendo com que a VEIC vença a inércia para abrir. Após um determinado intervalo de tempo, a intensidade da corrente baixa para um valor de regime, $i_{\mathrm{HD}}$. Geralmente tais circuitos são formados por um circuito integrado responsável por controlar a variação de corrente através da VEIC, a partir de um sinal disparador 
A FIGURA 30, ilustra a variação da corrente através de uma VEIC para os dois tipos de acionamento.

A técnica de excitação por tensão é empregada em VEICs com impedância entre 12 e 16 ohms, enquanto que, excitação por corrente é empregada em VEICs com impedância entre 2 e 3 ohms.

Para um estudo mais detalhado entre as diferenças, vantagens e desvantagens de cada modo de acionamento deve-se consultar PASSARINI (2002).

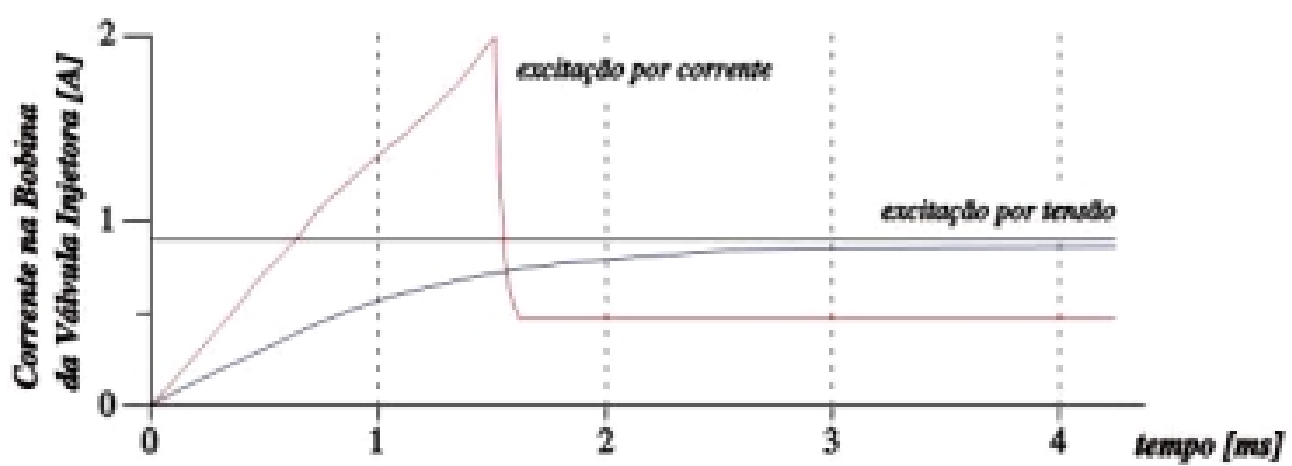

FIGURA 30 - Curvas de corrente para o acionamento de uma VEIC.

Com relação ao sistema projetado, este é capaz de atuar em ambos os modos de excitação. Além disso, quando a excitação por surto de corrente está sendo empregada, é possível configurar o circuito de forma a se obter os valores de pico e regime da corrente através da VEIC nos valores que forem necessários. O próximo capítulo, contém alguns resultados realizados para se verificar os dois tipos de acionamento a partir do sistema desenvolvido. O ANEXO D, contém o circuito de potência para acionamento das VEICs.

O diagrama representando as saídas do microcontrolador para acionamento das VEICs está no ANEXO B. Os sinais PB1, PB2, PB3 e PB4 (bits 1, 2, 3 e 4 da porta paralela B do microcontrolador, respectivamente), atuam como sinal de seleção (chip select). Quando estes sinais estiverem em nível lógico 1, as respectivas VEICs serão selecionadas. Já o sinal CT_OUT1, saída do contador 1, é responsável por gerar o tempo de abertura das VEICs. Este sinal é ativo em nível lógico 0 .

\subsubsection{Circuito para acionamento do estágio de potência da bobina de ignição}

O estágio de potência da bobina de ignição pode variar de acordo com o fabricante. Em alguns casos o estágio de potência encontra-se junto à bobina, enquanto em outros casos, 
este faz parte da unidade de controle. Na atual configuração do sistema, o hardware está preparado para atuar sobre bobinas de ignição que já contenham o estágio de potência. Desta forma, a energização da bobina de ignição é realizada a partir de um sinal de baixa potência, proveniente da unidade de controle. A FIGURA 31, contém o esquema do módulo de acionamento do estágio de potência da bobina de ignição.
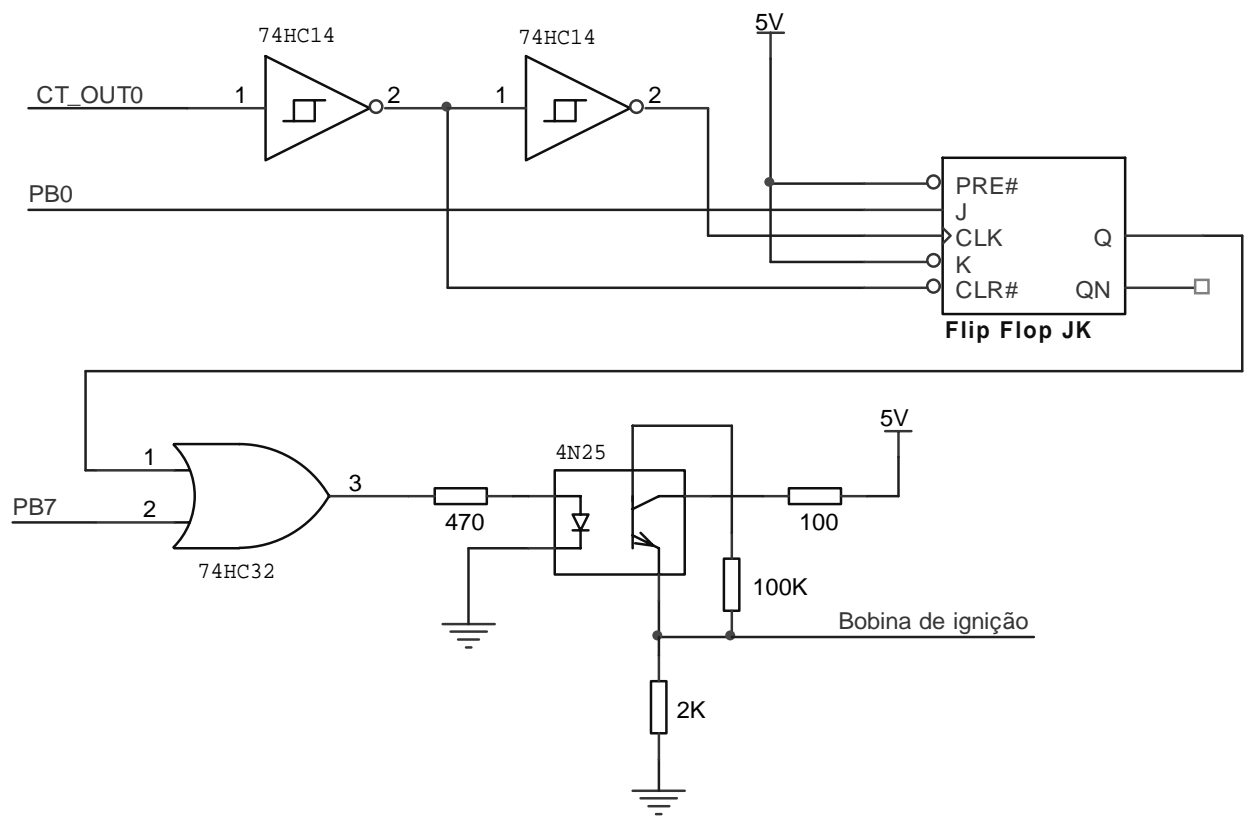

FIGURA 31 - Circuito para acionamento do estágio de potência da bobina de ignição.

No circuito projetado, existem dois sinais que podem energizar a bobina. Durante a partida, a bobina pode ser energizada a partir do sinal vindo de PB7 (bit 7 da porta paralela B do microcontrolador). Após este período, a bobina pode passar a ser energizada pelos sinais vindo de CT_OUT0 e PB0. O sinal gerado através de PB0 atua como sinal de seleção (chip select) e CT_OUT0, que corresponde a saída do Contador 0 do microcontrolador, determina o tempo de energização da bobina e é ativo em zero. Tanto PB0 como PB7 são ativos em nível lógico 1 (um). Na transição de PB7 de 1 para 0 ou de CT_OUT0 de 0 para 1, ocorre o centelhamento na vela de ignição. A TABELA 02, contém a relação entre os sinais gerados pelo microcontrolador e o correspondente evento gerado pelo sistema de acionamento do estágio de potência e a bobina de ignição. 
TABELA 02 - Tabela de sinais para gerar centelha na bonina de ignição.

\begin{tabular}{|c|c|c|c|c|}
\hline Acionamento & Sinal & $\begin{array}{c}\text { Seleção do } \\
\text { módulo }\end{array}$ & Energização & Centelhamento \\
\hline $\mathbf{I}$ & PB7 & $\uparrow$ & 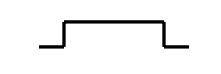 & $\downarrow$ \\
\hline \multirow{2}{*}{ II } & PBO & $\uparrow$ & $\mathbf{x}$ & $\mathbf{x}$ \\
\hline & CT_OUT0 & $X$ & 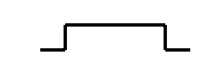 & $\downarrow$ \\
\hline $\begin{array}{ll}* & \uparrow \\
& \downarrow \\
& \\
& \\
& \end{array}$ & $\begin{array}{l}\text { Borda de subid } \\
\text { Borda de descic } \\
\text { Permanência en } \\
\text { Qualquer estado }\end{array}$ & $\begin{array}{l}\text { nal; } \\
\text { inal; } \\
\text { lógico 1; }\end{array}$ & & \\
\hline
\end{tabular}

No próximo capítulo, o sinal gerado para acionamento do estágio de potência, pelo sistema original, é comparado com o sinal gerado pelo sistema desenvolvido. Para testar o sistema, utilizou-se um motor VW AT1000 cujo sistema de gerenciamento é o Motronic MP9.0 (consultar o ANEXO C para maiores detalhes).

\subsubsection{Circuito de potência para acionamento do corretor da marcha lenta}

O circuito de potência desenvolvido, visa controlar o corretor da marcha lenta através de sinais enviados pela unidade central de processamento. Como foi descrito em 3.3.5.3 Corretor da marcha lenta, o atuador do corretor da marcha lenta utiliza um motor de passo ou um motor DC. O circuito de potência para acionamento do corretor da marcha lenta utilizado, é capaz de atuar tanto no motor de passo como no motor de corrente contínua. Este circuito é constituído de uma ponte-H com tensão máxima de $55 \mathrm{~V}$ e corrente de até $3 \mathrm{~A}$. A FIGURA 32, ilustra o módulo para acionamento do corretor da marcha lenta configurado para atuar sobre um motor DC.

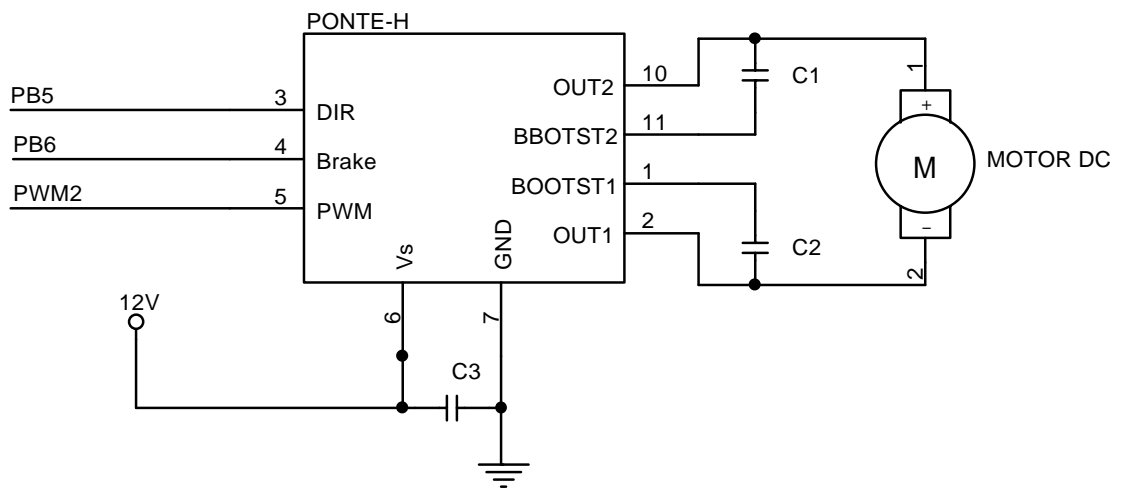

FIGURA 32 - Circuito para acionamento do corretor da marcha lenta 
O ANEXO B, mostra o diagrama com os sinais gerados pelo microcontrolador para acionar o corretor da marcha lenta. Este diagrama ilustra a montagem utilizada para a realização de testes no motor AT1000.

O sinal gerado por PWM2 (saída do PWM 2 do microcontrolador), é responsável por determinar a posição da borboleta de aceleração durante a marcha lenta. Sua freqüência é de $400 \mathrm{~Hz}$, a mesma utilizada pelo sistema original. A largura de pulso deste sinal é que define a posição angular da borboleta. O sinal gerado por PB5 informa o sentido de acionamento da borboleta de aceleração (abertura ou fechamento). A saída OUT1 deve ser conectada ao pino 1 do corpo da borboleta e a saída OUT2 ao pino $2^{13}$. Nesta configuração, o acionamento da borboleta de aceleração no sentido de abertura é executado quando PB5 $=0$ e o fechamento ocorre quando PB5 = 1. Já o sinal de PB6, desativa o sistema quando em nível lógico 1 juntamente com o corte do sinal de PWM2. Esta medida faz com que a energia consumida pelo circuito de potência seja mínima.

No próximo capítulo, faz-se comparações entre o sinal para acionamento do corretor da marcha lenta, gerado pelo sistema original (Motronic MP9.0) e pelo sistema desenvolvido.

${ }^{13}$ Deve-se atentar à conexão entre saída do circuito de potência e a alimentação do motor DC no corpo da borboleta, pois esta definirá a lógica de abertura e fechamento por PB5. 


\subsection{DESCRIÇÃO DO SOFTWARE}

Conforme comentado na introdução deste capítulo, a plataforma utilizada para o desenvolvimento do software de controle é a linguagem de programação ANSI C, pois é uma linguagem de nível intermediário, ou seja, está entre as linguagens de baixo nível como assembly e as linguagens de alto nível. Isso elimina a necessidade de se gerar códigos em assembly, o que reduz o tempo de programação e facilita a localização de erros; embora programas com códigos gerados no próprio assembly da unidade de processamento tendem a ser mais rápidos.

Nesta fase do trabalho, foram implementadas apenas as rotinas básicas para que o motor funcione permitindo que o hardware desenvolvido fosse testado. A FIGURA 33, contém o fluxograma do programa de controle para teste do hardware.

Este programa tem por função reconhecer o funcionamento do motor, e a partir do sinal do sensor Hall, identificar o momento correto de injeção, energização da bobina de ignição e posterior corte para gerar a centelha na vela de ignição.

O objetivo é fazer com que os atuadores entrem em funcionamento para testar os sistemas de potência desenvolvidos, bem como o circuito para leitura do sensor Hall. Como será visto no próximo capítulo, o motor utilizado para se testar o sistema é o AT1000 da VW. Isto implica na existência de algumas características específicas para o motor utilizado.

O ANEXO E, contém o código fonte gerado em C. 


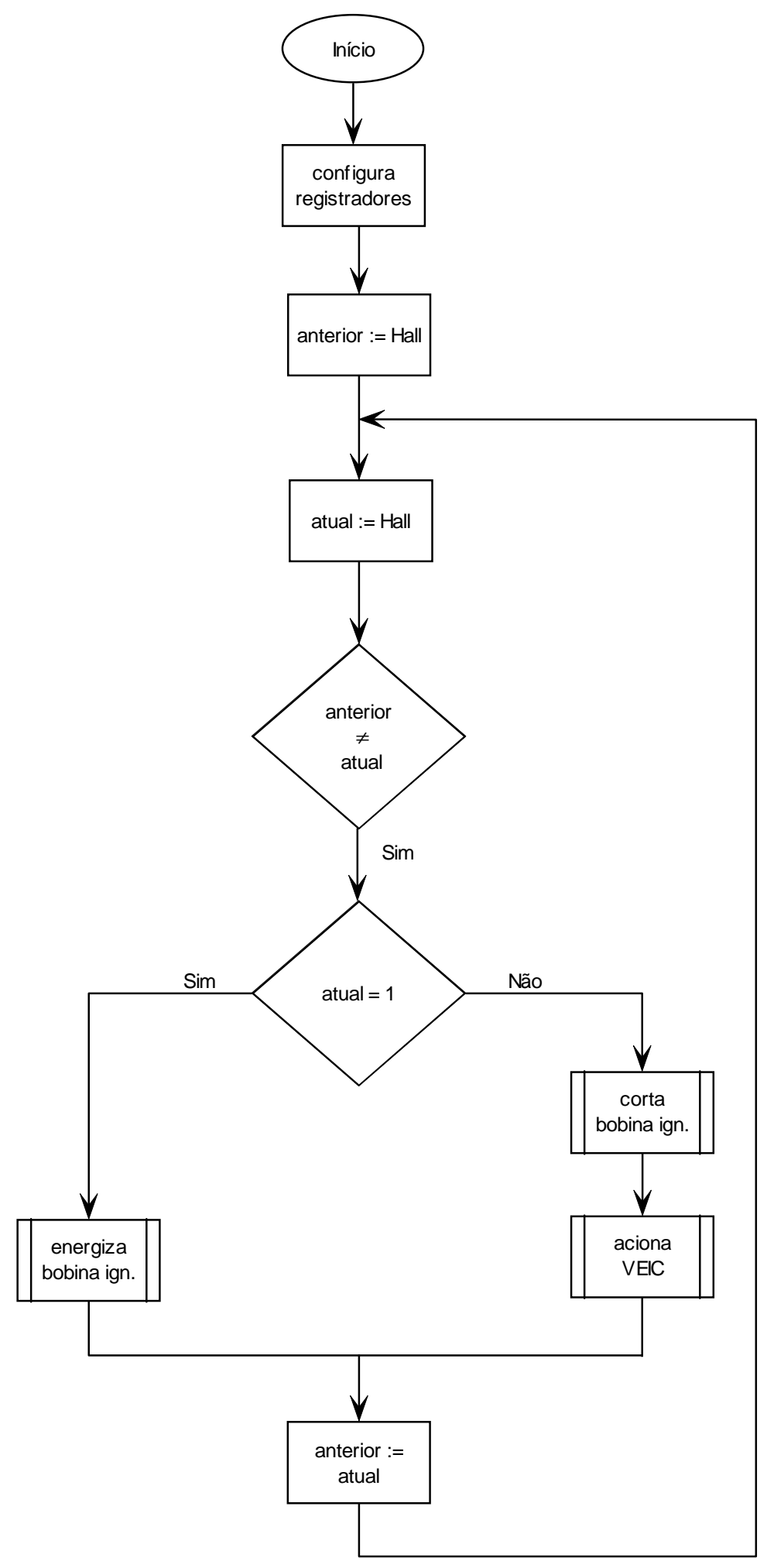

FIGURA 33 - Fluxograma do programa de controle para teste do hardware. 


\subsection{DESCRIÇÃO DO MOTOR UTILIZADO}

Para mostrar a capacidade do sistema de atuar sobre um motor, foi utilizado um propulsor VW modelo AT1000, modelo à etanol, cujo sistema de gerenciamento eletrônico é o Motronic MP9.0 da Bosch. As principais características do motor e do sistema de gerenciamento estão no ANEXO C.

\subsection{INSTRUMENTAÇÃO COMPLEMENTAR}

Foram utilizados os seguintes instrumentos para captura, análise e verificação dos sinais do sistema Motronic MP9.0 e do sistema desenvolvido:

$\checkmark$ Osciloscópio digital Hewlett Packard modelo 54602B;

$\checkmark$ Analisador lógico Hewlett Packard modelo 54620A;

$\checkmark$ Gerador de sinais Hewlett Packard modelo 33120A;

$\checkmark$ Multímetro digital Hewlett Packard modelo 974A;

$\checkmark$ Software VirtualBench ${ }^{\mathrm{TM}} 2.1 .1$ e placa de aquisição DAQScope ${ }^{\mathrm{TM}} 5102$ da NATIONAL INSTRUMENTS; 


\section{RESULTADOS ALCANÇADOS}

\subsection{INTRODUÇÃO}

Neste capítulo, será mostrado os resultados dos testes realizados para se verificar o funcionamento do sistema. Deve-se ressaltar que o objetivo do projeto não é implementar todas as funções realizadas por uma UCE para o gerenciamento de um motor C.I., mas sim desenvolver um sistema como o que foi descrito anteriormente e verificar a sua capacidade de atuar sobre um motor.

A partir do programa mostrado no item 4.3, o sistema desenvolvido atuou sobre o motor desde a partida, ou seja, em nenhum momento foi necessário a utilização do sistema original. Isto mostra a capacidade do sistema atuar sobre o motor mesmo durante condições consideradas críticas, como é a partida do motor. Durante o teste foi implementada uma estratégia de injeção simultânea, ou seja, o combustível era injetado em todos os cilindros simultaneamente. 


\subsection{RESULTADOS ALCANÇADOS}

\subsubsection{Teste do sistema de acionamento das VEICs}

Testes realizados para se constatar a versatilidade do sistema de potência para acionamento das VEICs foram realizados em duas VEICs diferentes, uma com impedância de $2 \Omega$ (típica de um sistema SPFI) e outra com impedância de $12 \Omega$ (típica de um sistema MPFI).

O procedimento utilizado constou em conectar a VEIC no circuito projetado e medir a corrente através desta. Para se medir a corrente, utilizou-se uma resistência de prova de $0,1 \Omega$ conectada em série com a VEIC como mostra a FIGURA 34. Um amplificador foi utilizado para eliminar ruído na leitura do sinal pelo osciloscópio. Utilizou-se o software VirtualBench $^{\mathrm{TM}} 2.1 .1$ e a placa de aquisição DAQScope ${ }^{\mathrm{TM}}$ 5102, da NATIONAL INSTRUMENTS $^{\circledR}$ para emular um osciloscópio na tela de um computador pessoal, afim de permitir a captura de tela do instrumento.

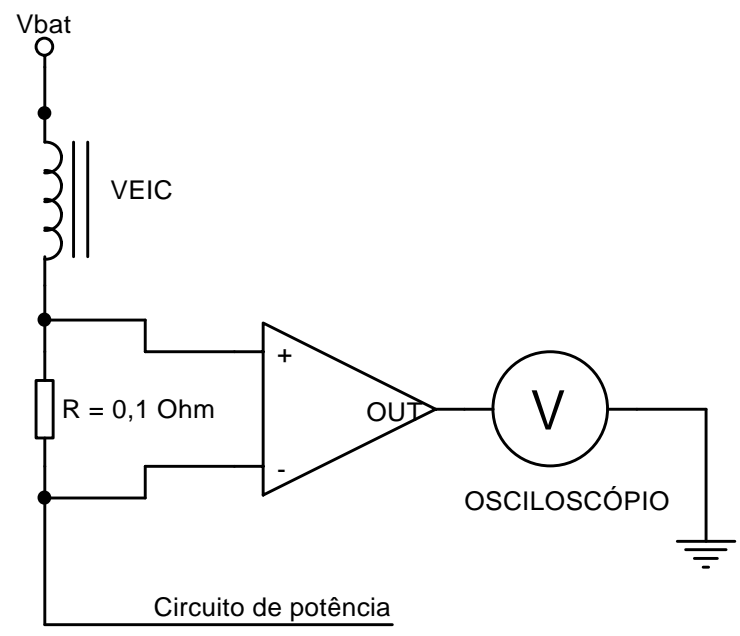

FIGURA 34 - Dispositivo para medida de corrente na VEIC.

A FIGURA 35, corresponde à corrente através da VEIC de $2 \Omega$. O ganho do amplificador utilizado para este sinal foi de 11 vezes. Assim o valor de pico da tensão lida no osciloscópio corresponde a:

$$
V_{P K}=\frac{4,3}{11}=0,39 \mathrm{~V}
$$

Este valor corresponde à queda de tensão na resistência de prova em série com a VEIC. Portanto o valor de pico da corrente será: 


$$
i_{P K}=\frac{0,39}{0,1}=3,9 \mathrm{~A}
$$

Com relação ao valor de regime, tem-se:

$$
V_{H D}=\frac{1,0}{11}=0,091 \mathrm{~V}
$$

O que corresponde a uma corrente de regime de:

$$
i_{H D}=\frac{0,091}{0,1}=0,91 \mathrm{~A}
$$

Como pode ser observado, este sinal é indicativo de que a VEIC está sendo acionada por surte de corrente conforme o esperado.

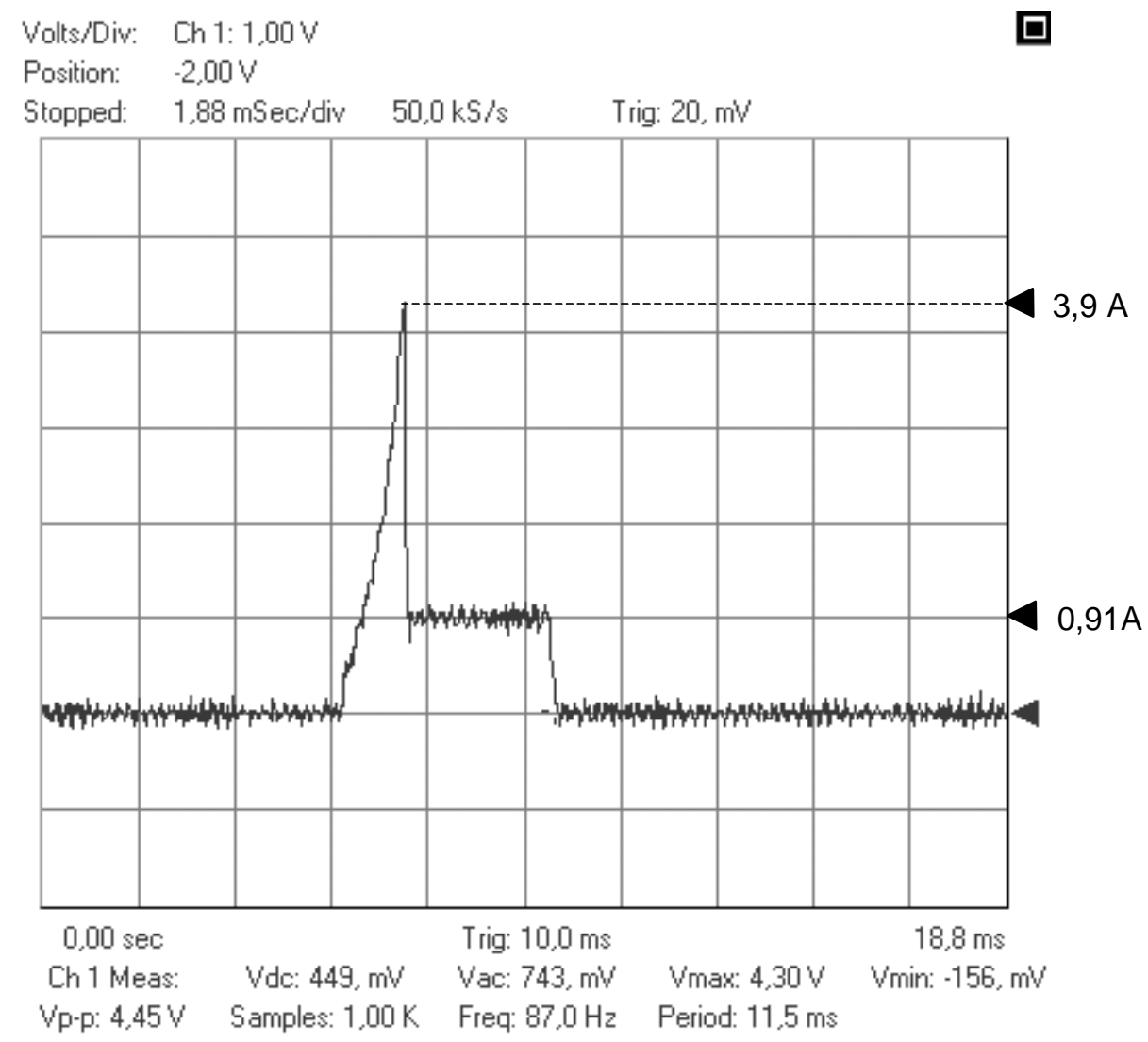

FIGURA 35 - Reprodução da tela do osciloscópio mostrando a corrente através da VEIC sob excitação por surto de corrente.

O mesmo procedimento foi aplicado à uma VEIC de $12 \Omega$ de impedância. Neste caso, o ganho do amplificador, mostrado na FIGURA 34, foi de 43,5 vezes. A FIGURA 36, corresponde a corrente através desta VEIC. Pela curva, pode se observar que a corrente máxima é de: 


$$
\begin{gathered}
V_{\max }=\frac{4,2}{43,5}=0,097 \mathrm{~V} \\
i_{\max }=\frac{0,097}{0,1} 0,97 \mathrm{~A}
\end{gathered}
$$

Este valor está próximo do esperado, considerando que o valor máximo da corrente através de uma VEIC, quando acionada por surto de tensão, obedece a lei de Ohm, ou seja:

$$
\mathrm{U}=\mathrm{R} \times \mathrm{I}
$$

onde $\mathrm{U}$ é a tensão aplicada, $\mathrm{R}$ a resistência do componente e I a corrente através deste.

No ensaio realizado, a tensão da bateria era de $11,8 \mathrm{~V}$, e o valor esperado da corrente máxima era $0,98 \mathrm{~A}$, o que está bem próximo do valor medido.

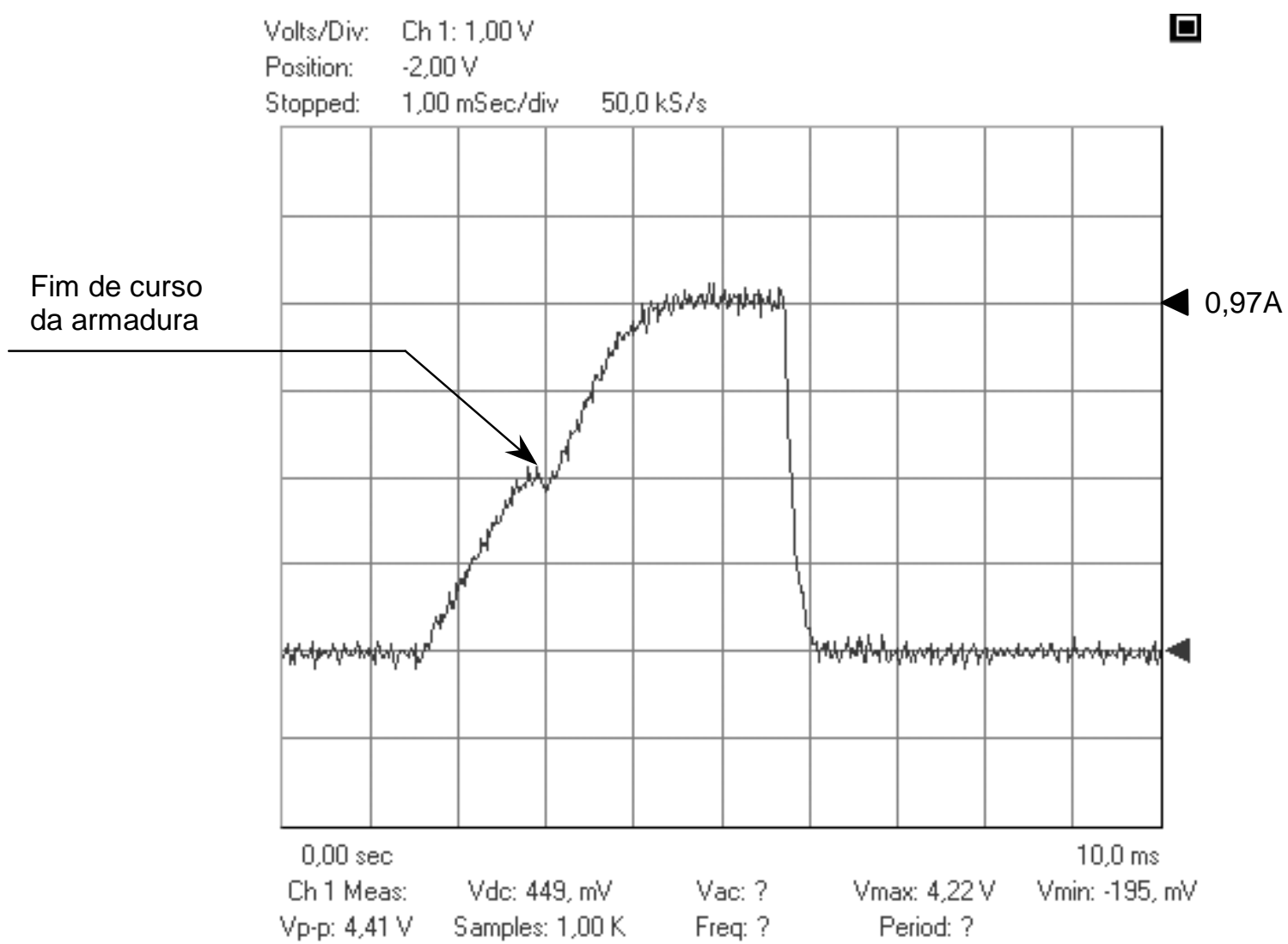

FIGURA 36 - Reprodução da tela do osciloscópio mostrando a corrente através da VEIC sob excitação por surto de tensão.

Desta forma, pode-se verificar que o circuito de potência utilizado no sistema desenvolvido, é capaz de acionar qualquer tipo de VEIC, o que demostra sua versatilidade para atuar em diferentes tipos de motores ciclo Otto. 


\subsubsection{Teste do sistema de energização da bobina de ignição}

Verificou-se o funcionamento do sistema de acionamento do estágio de potência da bobina de ignição, utilizando-se o motor AT1000 da VW, cujo sistema de gerenciamento original é o Motronic MP9.0.

O sinal medido para se verificar tal funcionamento, corresponde ao sinal de acionamento do módulo de potência da bobina de ignição. Este módulo encontra-se junto à bobina no caso do sistema MP9.0. A FIGURA 37, ilustra, esquematicamente, o procedimento utilizado para se medir tal sinal.

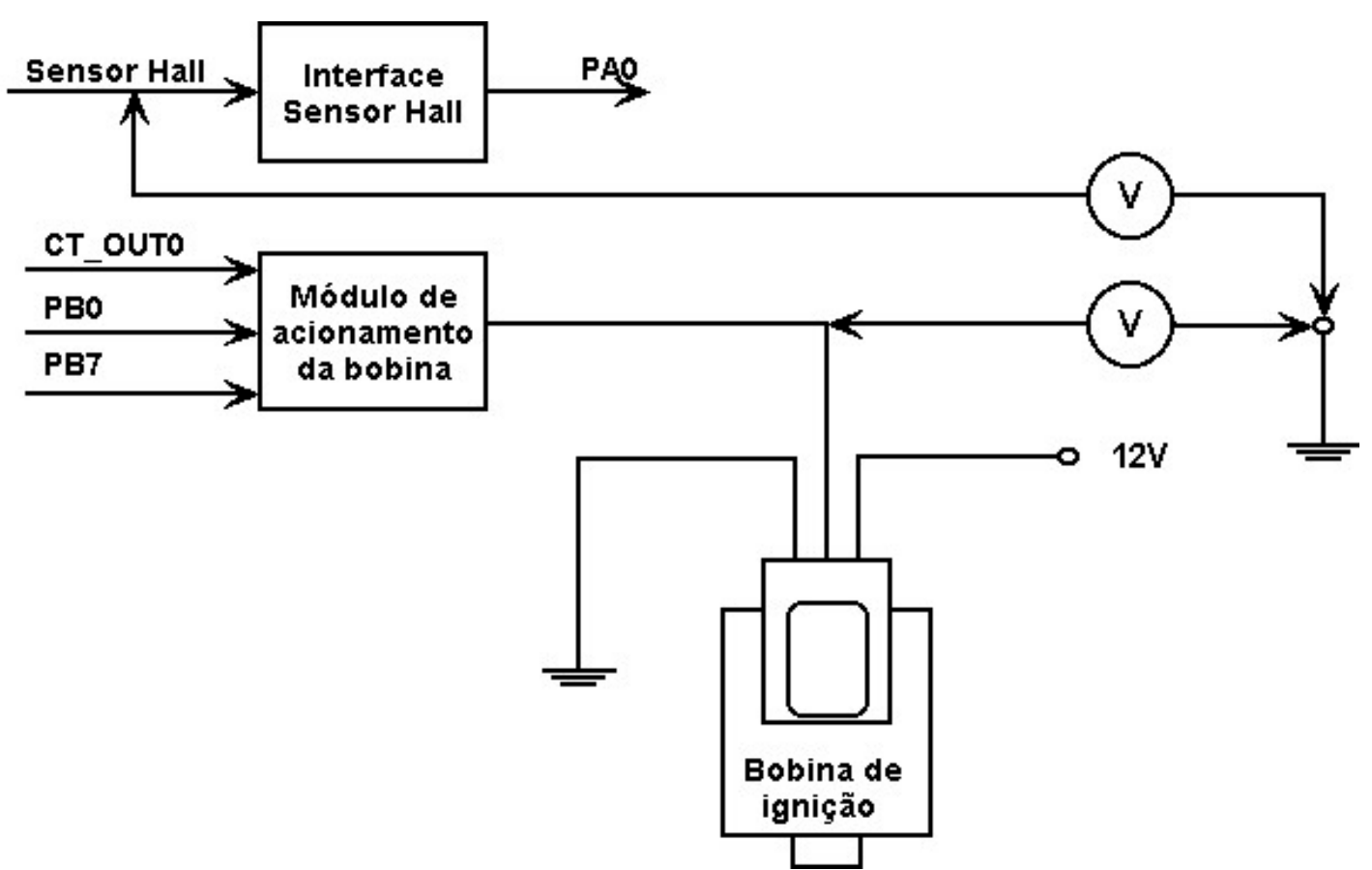

FIGURA 37 - Medida do sinal de acionamento do módulo de potência da bobina de ignição.

A partir do software descrito no item 4.3, o motor entrou em funcionamento sob atuação do sistema desenvolvido. Utilizou-se o software VirtualBench $^{\mathrm{TM}} 2.1 .1$ e a placa de aquisição DAQScope $^{\mathrm{TM}}$ 5102, da NATIONAL INSTRUMENTS ${ }^{\circledR}$ para emular um osciloscópio na tela de um computador pessoal e registrar o sinal gerado para acionar o módulo de potência da bobina e o sinal do sensor Hall. A FIGURA 38, contém os sinais registrados. Deve-se observar que, a curva referente ao sinal do sensor Hall está atenuada de 10 vezes, devido às restrições da placa de aquisição utilizada para o experimento em questão. Portanto sua amplitude real é de 12 Volts, aproximadamente. 
Sinal de acionamento do módulo de potência

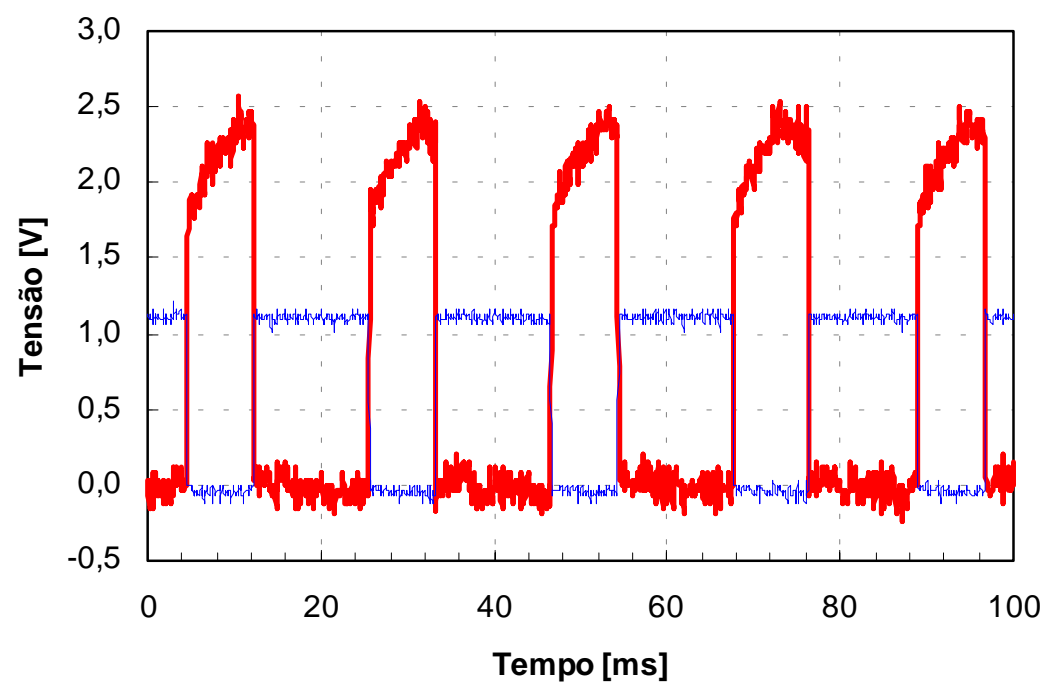

_ Acionamento do módulo de potência —_ Sensor Hall

FIGURA 38 - Sinal para acionamento do módulo de potência da bobina de ignição.

O sinal gerado pelo sistema original está na FIGURA 39, juntamente com o sinal do sensor Hall. O mesmo procedimento do caso anterior, foi utilizado para se registrar o sinal gerado pelo sistema original.

Sinal de acionamento do módulo de potência

(Sistema MP9.0)

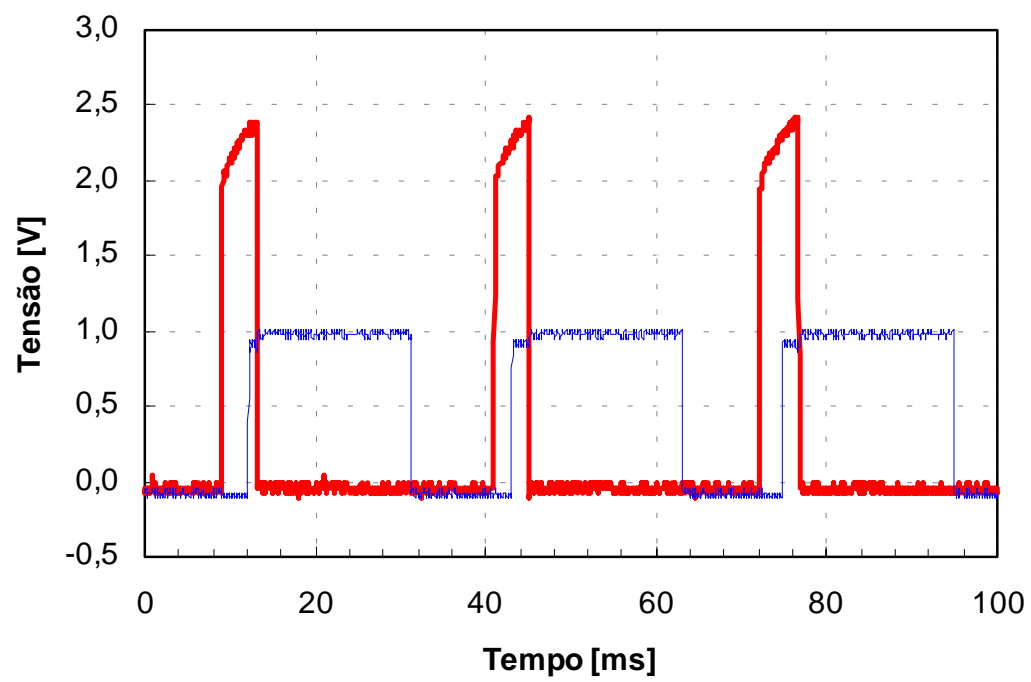

_ Acionamento do módulo de potência —_ Sensor Hall

FIGURA 39 - Sinal para acionamento do módulo de potência da bobina de ignição (sistema original). 
Como pode ser observado, no sistema original, o tempo de energização da bobina de ignição corresponde a aproximadamente, $5 \mathrm{~ms}$. Este valor é fixo para toda a faixa de operação do motor. No caso do sistema desenvolvido, a energização ocorre em sincronismo com o sinal do sensor Hall. Portanto, neste caso, o tempo de energização varia de acordo com a rotação do motor. Esta estratégia foi adotada para simplificar o software, porque o objetivo do ensaio era verificar o funcionamento do sistema desenvolvido, mas a adoção de uma estratégia com tempo fixo fica como sugestão para trabalhos futuros. Mantendo-se o tempo de energização fixo, garante-se que a bobina terá energia suficiente para gerar a centelha na vela de ignição, independentemente da rotação do motor. Quanto maior o tempo de energização maior será a energia armazenada no primário da bobina.

Apesar desta diferença de estratégia, o sistema para acionamento do módulo de potência da bobina de ignição do sistema desenvolvido é capaz de gerar o mesmo sinal que o sistema original. Embora se tenha tentado obter o sinal de saída do secundário da bobina de ignição (aproximadamente $30 \mathrm{KV}$ ), este sinal não foi medido por falta de equipamento adequado para isto. Constatou-se, também, que o sinal do sensor Hall está sendo, adequadamente, reconhecido pelo sistema de gerenciamento desenvolvido. Este sinal é imprescindível para que o motor entre em funcionamento, pois sem este, é impossível reconhecer o funcionamento do motor no momento da partida e realizar o sincronismo do momento correto da injeção e da ignição.

\subsubsection{Teste do sistema para acionamento do corretor da marcha lenta}

Novamente, foi utilizado o motor AT1000 para se avaliar o sistema de acionamento do corretor da marcha lenta. $\mathrm{O}$ atuador neste caso é um motor de corrente contínua. Para se verificar o funcionamento do sistema desenvolvido, o microcontrolador gerou dois sinais PWM com largura de pulso de $24 \%$ e $32 \%$, o qual foi medido juntamente com a queda de tensão através do motor DC. Os sinais foram registrados utilizando-se o software VirtualBench $^{\mathrm{TM}} 2.1 .1$ e a placa de aquisição DAQScope ${ }^{\mathrm{TM}}$ 5102, da NATIONAL INSTRUMENTS $^{\circledR}$. A FIGURA 40, ilustra o procedimento adotado para medir os sinais. 


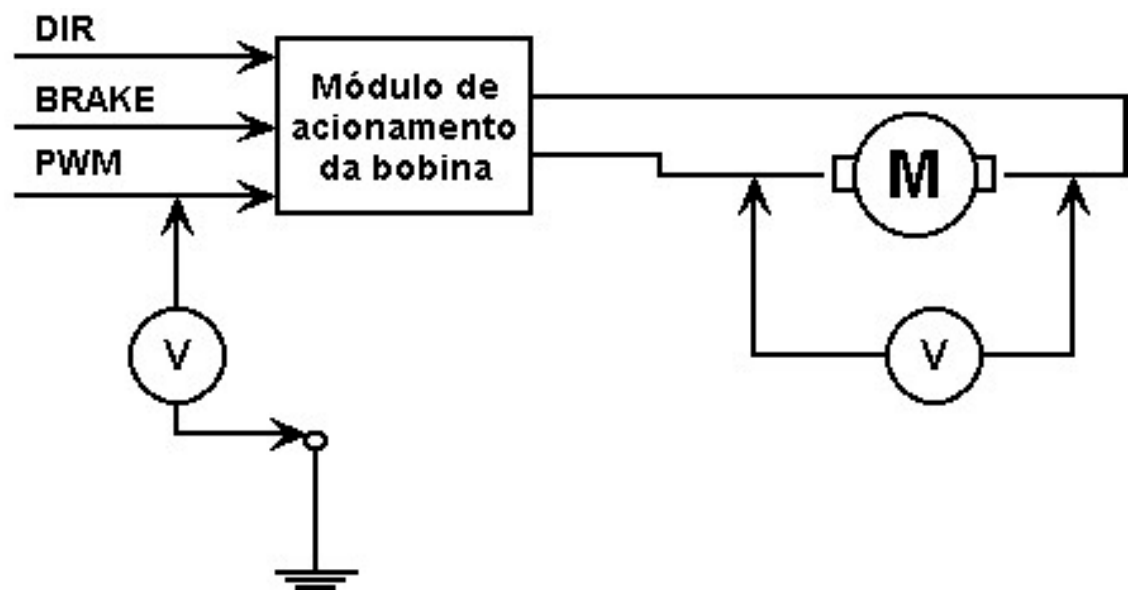

FIGURA 40 - Medida do sinal de acionamento do corretor da marcha lenta.

A seguir, nas FIGURA 41e FIGURA 42, tem-se os sinais para os dois valores de largura de pulso.

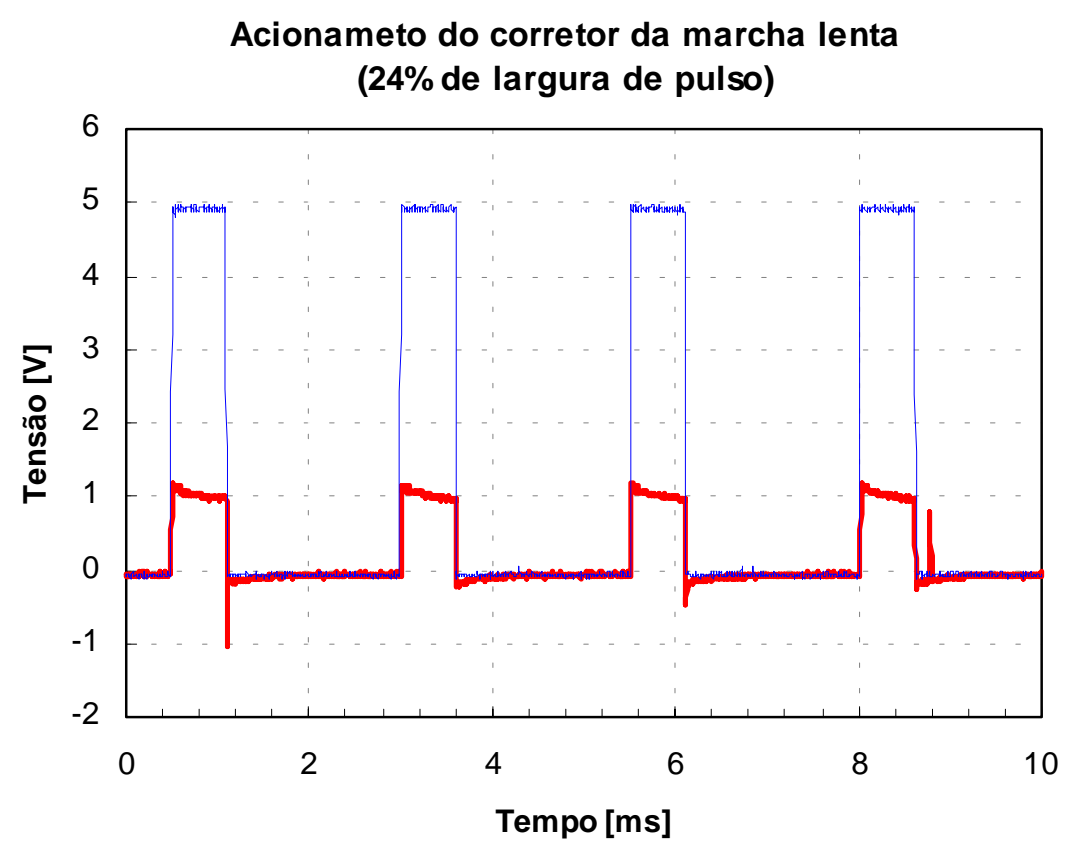

Corretor da marcha lenta __ PWM (24\% largura de pulso)

FIGURA 41 - Acionamento do corretor da marcha lenta com $24 \%$ de largura de pulso. 


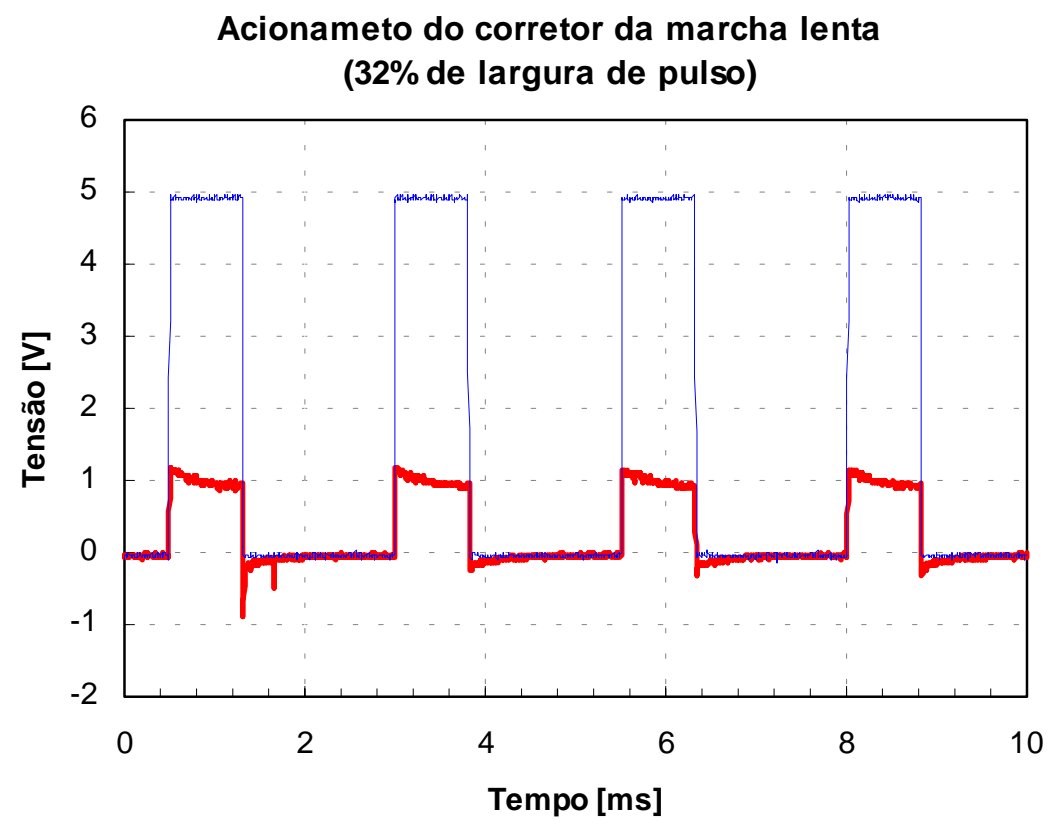

_Corretor da marcha lenta _ PWM (32\% largura de pulso)

FIGURA 42 - Acionamento do corretor da marcha lenta com $32 \%$ de largura de pulso.

Deve-se ressaltar que, devido às restrições da placa de aquisição, o sinal atuante sobre o motor de corrente contínua, está atenuado de 10 vezes. Portanto a amplitude real, corresponde a 12 Volts, aproximadamente.

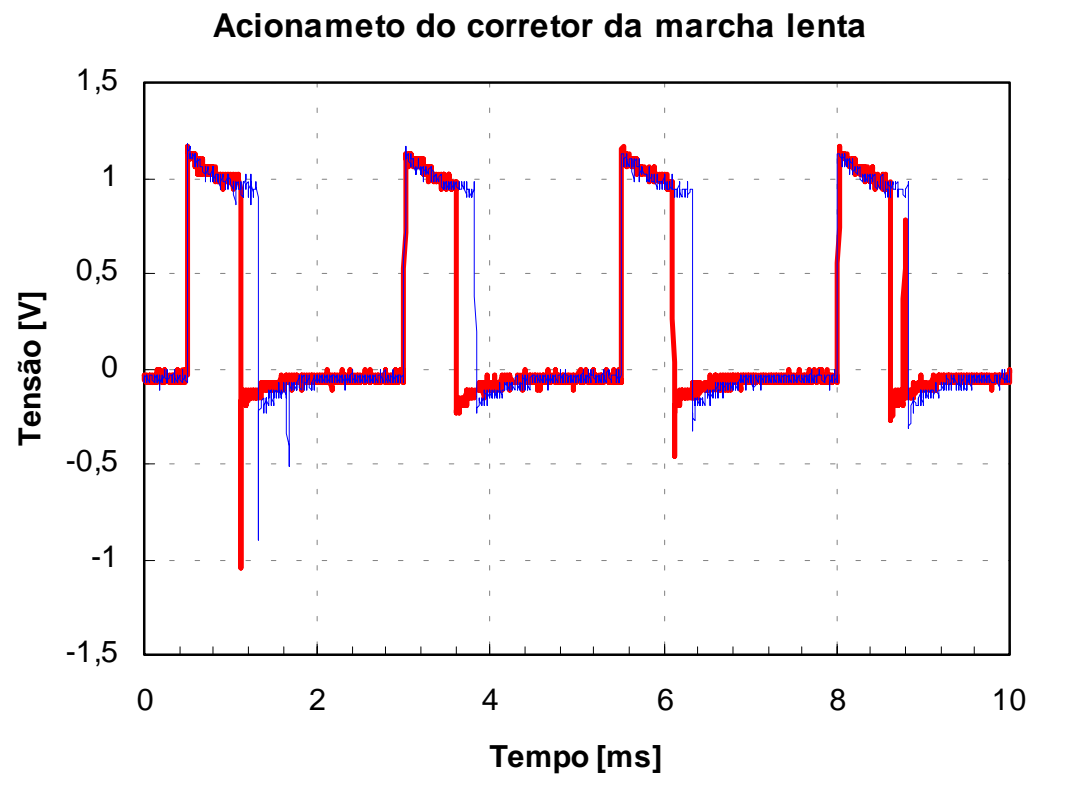

_ PWM (24\% largura de pulso) __ PWM (32\% largura de pulso)

FIGURA 43 - Sinal atuante para diferentes valores de largura de pulso. 
A FIGURA 43, compara os dois sinais atuantes, com os dois valores de largura de pulso. Quanto maior a largura de pulso, maior será o deslocamento angular da borboleta, seja no sentido de abertura ou fechamento.

Ressalta-se aqui que, neste teste, objetivou-se constatar que o sistema de potência para acionamento do corretor da marcha lenta desenvolvido, é capaz de atuar sobre o corretor da marcha lenta em questão.

A FIGURA 44, mostra o sinal gerado pelo sistema original (MP9.0).

Está claro, portanto, que o sistema para acionamento do corretor da marcha lenta é capaz de gerar o mesmo sinal, se comparado ao sistema original.

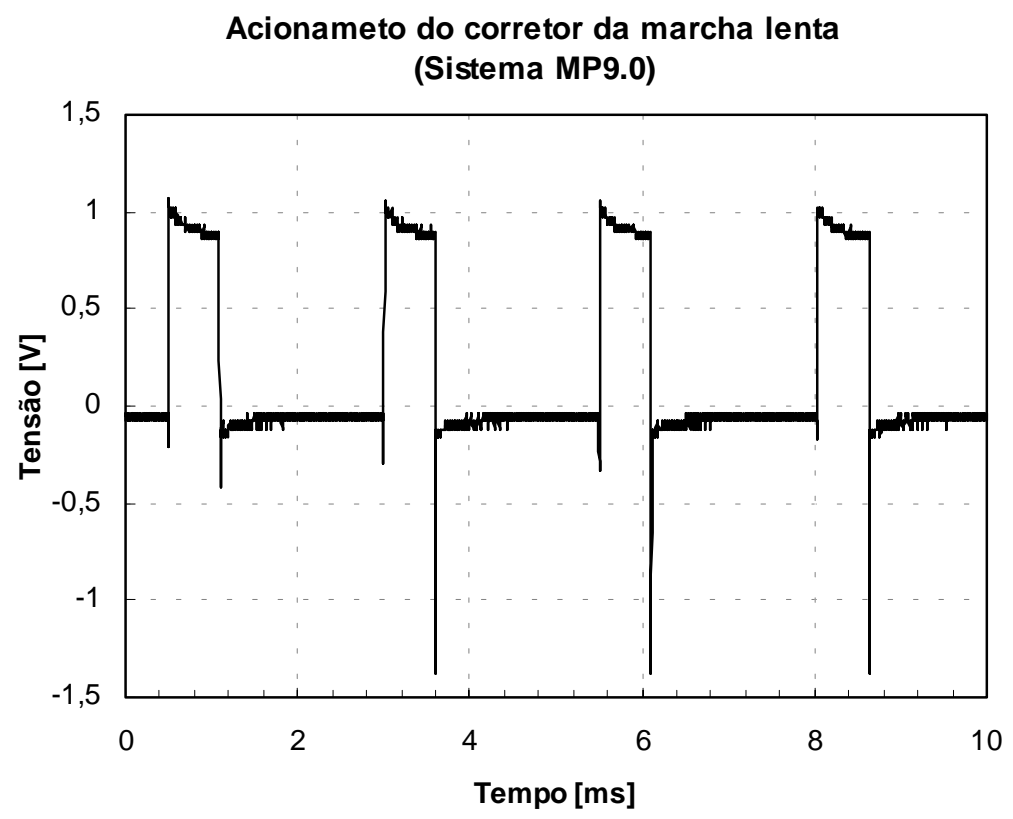

FIGURA 44 - Acionamento do corretor da marcha lenta (sistema original). 


\section{CONCLUSÕES}

Os resultados alcançados mostraram que o sistema de desenvolvimento é capaz de controlar um motor de ciclo Otto, independente de seu sistema de controle original. O sistema de estrutura aberta, desenvolvido de acordo com as necessidades de pesquisa, foi capaz de atuar de maneira semelhante ao sistema original.

Nos testes realizados, ficou demonstrado que os sistemas de potência conseguiram atuar adequadamente nas VEICs, na bobina de ignição e no corretor da marcha lenta. Além disso, o sistema de aquisição de sinais digitais desenvolvido foi capaz de identificar o sinal gerado pelo sensor Hall, possibilitando assim, que fossem reconhecidos os momentos da injeção de combustível e da ignição.

Com este trabalho, abre-se inúmeras possibilidades de pesquisa, seja modificando-se as formas de controle, desenvolvendo novos sensores e atuadores ou estudando novos combustíveis alternativos.

Dentro da proposta inicial, o objetivo foi alcançado, ou seja, foi construído um sistema de desenvolvimento para pesquisas relacionadas ao controle eletrônico dos motores a combustão interna. A tendência mundial no que se refere à capacidade de processamento dos processadores foi seguida, já que a tecnologia utilizada está à frente do que é utilizado no mercado. $\mathrm{O}$ desenvolvimento de algoritmos mais complexos que envolvam um número maior de variáveis a serem lidas e controladas poderá ser realizado em trabalhos futuros, uma vez que a base do sistema já está construída.

Fica portanto, como sugestão para trabalhos futuros os seguintes itens:

$\checkmark$ Adoção de uma estratégia de energização da bobina de ignição com tempo fixo;

$\checkmark$ Desenvolvimento de algoritmos mais complexos como rotação-densidade, controle a malha fechada (utilizando sensor de oxigênio), compensação do avanço da ignição e controle da marcha lenta;

$\checkmark$ Controle da aceleração utilizando sistema de acionamento eletrônico da borboleta de aceleração (drive-by-wire); 
Adição de um display digital para a visualização de parâmetros de interesse;

$\checkmark$ Permitir que parâmetros de controle sejam alterados em tempo real, sem a necessidade de se compilar um novo código fonte;

Considerando que o desenvolvimento de sistemas de gerenciamento de motores a combustão interna é de exclusividade das matrizes das empresas que estão instaladas no Brasil, e que esta tecnologia é tratada como segredo industrial, os resultados obtidos neste trabalho representa um grande avanço no sentido de dar os primeiros passos para pesquisas que envolvam implementação de técnicas de controle aplicadas aos motores a combustão interna, bem como a possibilidade de se ter uma ferramenta para pesquisas relacionadas com o aumento da eficiência dos motores, tais que, necessitem de alterações de parâmetros ou estratégias de controle dos sistemas originais. 
ANEXO A

Modos de controle aplicados durante a operação de um motor.

\begin{tabular}{|c|c|c|c|c|c|c|c|c|}
\hline \multirow{6}{*}{ 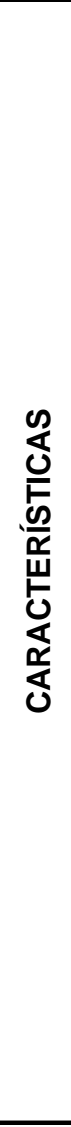 } & 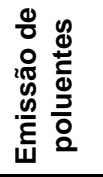 & $\overbrace{\substack{\pi \\
2}}^{\frac{\frac{\pi}{0}}{\frac{\pi}{0}}}$ & $\frac{\substack{\frac{\pi}{0} \\
\frac{\pi}{2}}}{\frac{\pi}{0}}$ & $\begin{array}{l}\frac{\pi}{0} \\
\frac{\pi}{0} \\
0 \\
\overline{\underline{D}} \\
0 \\
0\end{array}$ & $\begin{array}{l}\frac{\pi}{8} \\
\frac{\pi}{0} \\
0 \\
\overline{0} \\
0 \\
0\end{array}$ & $\frac{\frac{\pi}{\frac{\pi}{0}}}{2} \frac{\frac{\pi}{0}}{\frac{\pi}{0}}$ & $\begin{array}{l}\frac{\pi}{0} \\
\frac{\pi}{0} \\
0 \\
\frac{\underline{2}}{0} \\
0\end{array}$ & 尝 $\frac{\frac{\pi}{\frac{\pi}{0}}}{\frac{\pi}{0}}$ \\
\hline & 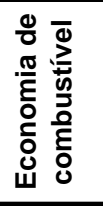 & 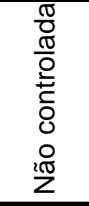 & 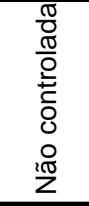 & 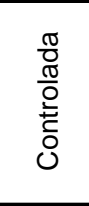 & $\begin{array}{l}\frac{\pi}{0} \\
\frac{\pi}{0} \\
0 \\
0 \\
0 \\
0\end{array}$ & $\begin{array}{l}\frac{\pi}{0} \\
\frac{\pi}{0} \\
0 \\
0 \\
0 \\
0 \\
0 \\
20 \\
2 \\
\end{array}$ & 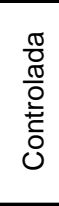 & $\begin{array}{l}\frac{\pi}{0} \\
\frac{\pi}{0} \\
\frac{\pi}{2} \\
0 \\
0 \\
0 \\
\frac{\pi 0}{2} \\
\end{array}$ \\
\hline & 舀 & 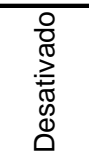 & $\begin{array}{l}\text { O } \\
\mathbb{0} \\
\stackrel{0}{ \pm} \\
\overline{0} \\
0 \\
0 \\
0\end{array}$ & 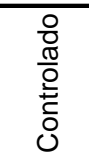 & $\begin{array}{l}0 \\
0 \\
\frac{0}{0} \\
0 \\
0 \\
0 \\
0 \\
0\end{array}$ & 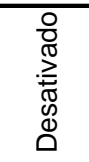 & 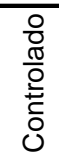 & 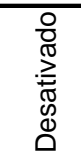 \\
\hline & 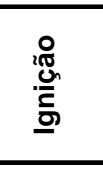 & 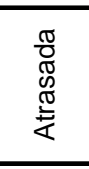 & $\begin{array}{l}\frac{\pi}{0} \\
\frac{\pi}{0} \\
\frac{0}{2} \\
0 \\
0 \\
\end{array}$ & $\begin{array}{l}\frac{\pi}{0} \\
\frac{\pi}{0} \\
0 \\
\frac{\pi}{0} \\
0 \\
0\end{array}$ & $\begin{array}{l}\frac{\pi}{0} \\
\frac{\pi}{0} \\
\frac{0}{0} \\
0 \\
0 \\
\end{array}$ & $\begin{array}{l}\frac{\pi}{0} \\
\frac{\pi}{0} \\
0 \\
0 \\
0 \\
0 \\
\end{array}$ & 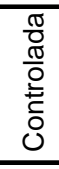 & $\begin{array}{l}\frac{\pi}{0} \\
\frac{\pi}{0} \\
\frac{\pi}{0} \\
\overline{0} \\
0 \\
\end{array}$ \\
\hline & 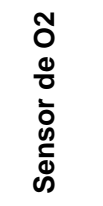 & 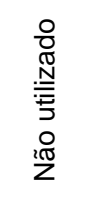 & 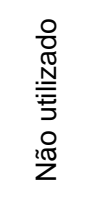 & 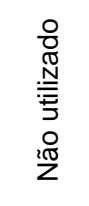 & 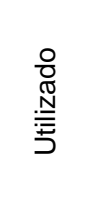 & 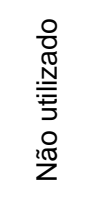 & 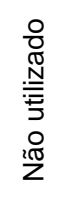 & 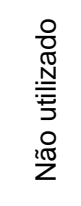 \\
\hline & 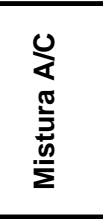 & $\stackrel{\widetilde{J}}{\widetilde{\pi}}$ & $\frac{\mathscr{J}}{\tilde{\pi}}$ & 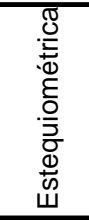 & 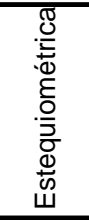 & 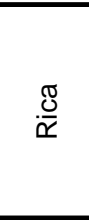 & $\begin{array}{l}0 \\
\stackrel{0}{0} \\
0\end{array}$ & $\stackrel{\widetilde{\pi}}{\widetilde{\sim}}$ \\
\hline & 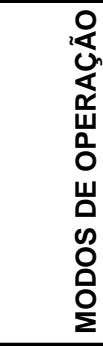 & 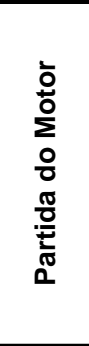 & 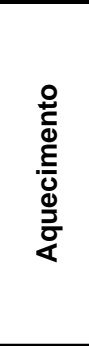 & 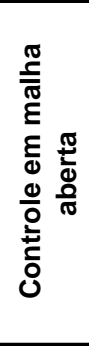 & 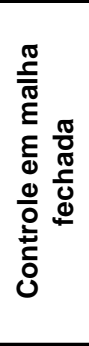 & 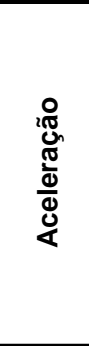 & 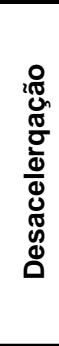 & 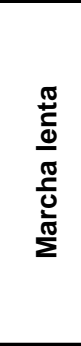 \\
\hline
\end{tabular}




\section{ANEXO B}

Diagrama em blocos do sistema.

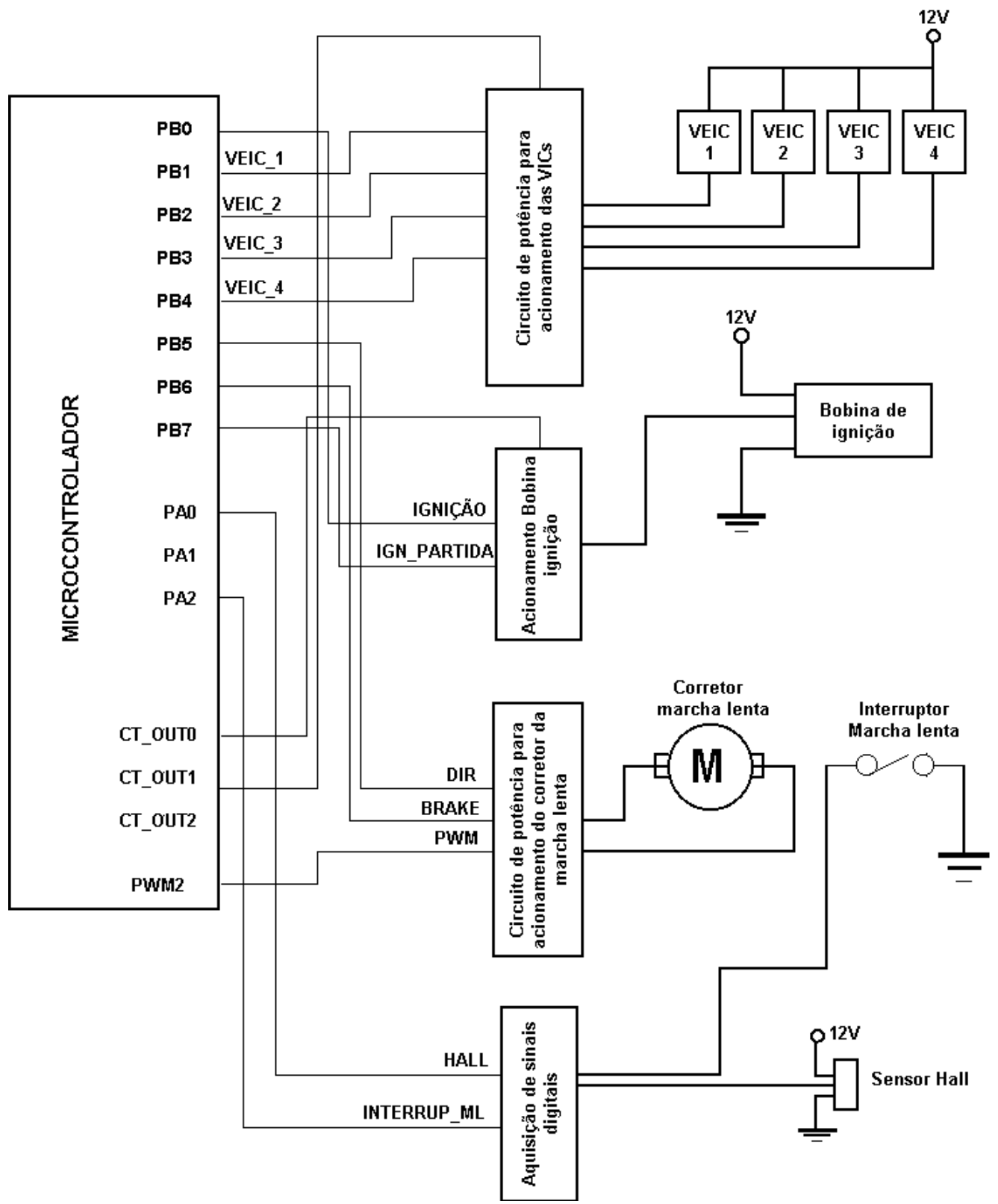

FIGURA 45 - Esquema geral do sistema projetado. 


\section{ANEXO C}

\section{Descrição da planta (Motor VW modelo AT1000).}

Dados técnicos do motor utilizado para testar o sistema de controle desenvolvido.

TABELA 04 - Dados técnicos do motor AT1000.

\begin{tabular}{|c|c|}
\hline Fabricante & Volkswagen do Brasil Ltda \\
\hline Modelo & AT1000 \\
\hline Combustível & Etanol \\
\hline Sistema de gerenciamento & Motronic MP9.0 \\
\hline Diâmetro dos cilindros & $67,1 \mathrm{~mm}$ \\
\hline Curso do êmbolo & $70,6 \mathrm{~mm}$ \\
\hline Cilindrada & $999 \mathrm{~cm}^{3}$ \\
\hline Relação de compressão & $10,5: 1$ \\
\hline Potência máxima & $46 \mathrm{Kw}$ a $5400 \mathrm{rpm}$ \\
\hline Torque máximo & 89,5 N.m a 3800 rpm \\
\hline Fluxo dos gases & Fluxo cruzado \\
\hline \multicolumn{2}{|l|}{ Alimentação } \\
\hline Injeção & Multiponto \\
\hline Pressão & $3,0 \pm 0,2$ bar \\
\hline \multicolumn{2}{|l|}{ Distribuidor } \\
\hline Localização & No cabeçote \\
\hline Acionamento & Comando de válvulas \\
\hline Índice de CO na marcha lenta & 0,2 a $0,8 \%$ \\
\hline Peso do motor com óleo & $95,0 \mathrm{Kg}$ \\
\hline
\end{tabular}


Dados técnicos do sistema Motronic MP9.0.

TABELA 05 - Dados técnicos do sistema Motronic MP9.0.

\begin{tabular}{|c|c|}
\hline Fabricante & Bosch \\
\hline \multicolumn{2}{|l|}{ Injeção } \\
\hline Tipo & Multiponto seqüencial \\
\hline \multirow[t]{2}{*}{ Resistência elétrica das VEICs } & $12 \mathrm{ohms}$ \\
\hline & realimentação por Sonda lambda \\
\hline \multicolumn{2}{|l|}{ Ignição } \\
\hline Tipo & Rotativa \\
\hline Seqüência & $1-3-4-2$ \\
\hline \multirow[t]{2}{*}{ Avanço inicial em marcha-lenta } & $6^{\circ}$ antes do PMS \\
\hline & $\begin{array}{l}\text { controle da detonação para cada } \\
\text { cilindro }\end{array}$ \\
\hline \multicolumn{2}{|l|}{ Controle da Marcha lenta } \\
\hline Atuador & Motor DC \\
\hline Rotação & $850 \pm 50 \mathrm{rpm}$ \\
\hline Sensor de rotação e PMS & Sensor Hall \\
\hline
\end{tabular}


ANEXO D

Circuito de potência para acionamento das VEICs. 


\section{ANEXO E}

\section{Código fonte do programa para teste do Hardware.}

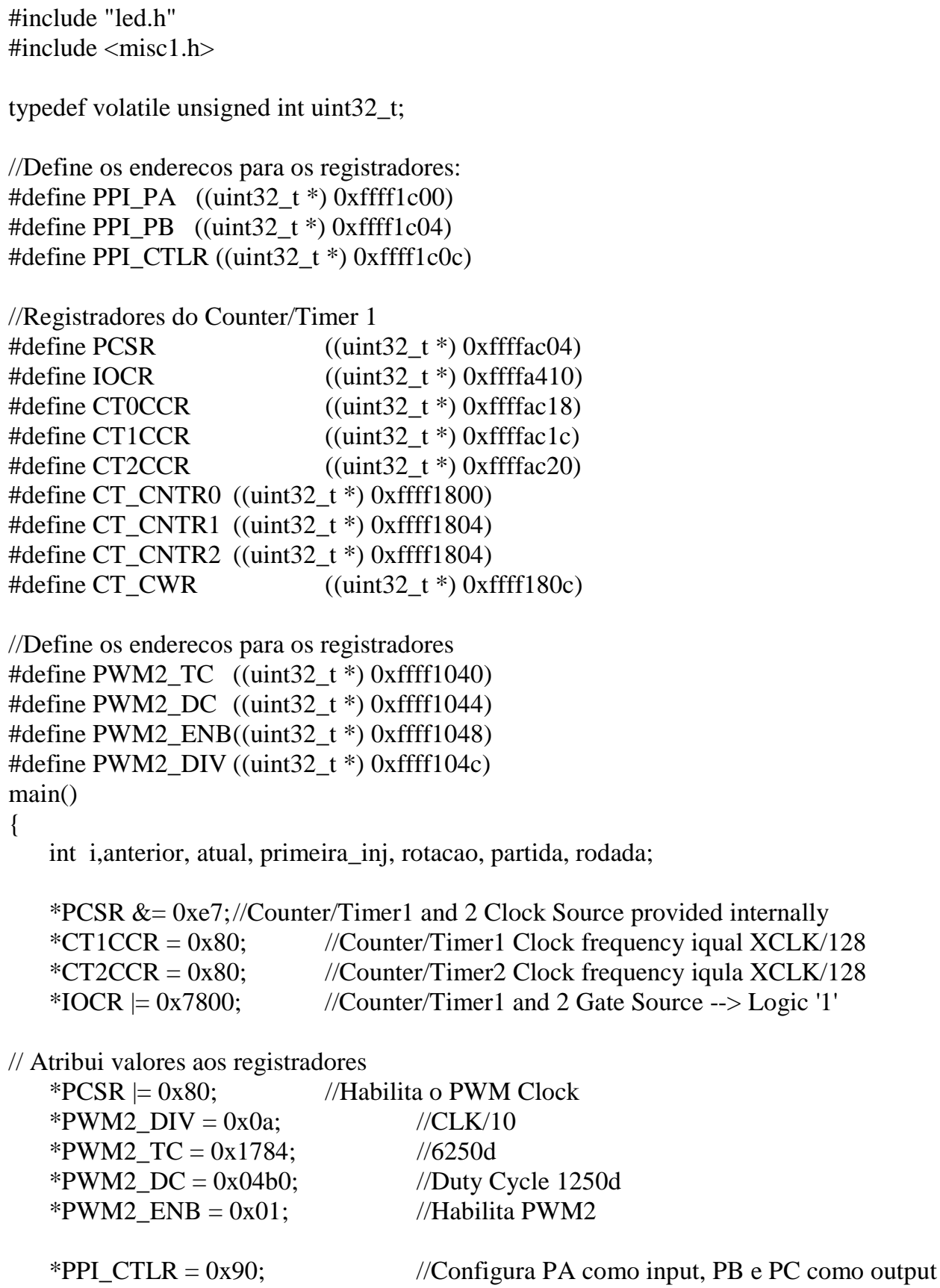

$*$ PCSR $\mid=0 \times 80$;

$*$ PWM2_DIV $=0 \mathrm{x} 0 \mathrm{a}$;

*PWM2_TC $=0 \times 1784$;

$* \mathrm{PWM} 2 \_\mathrm{DC}=0 \mathrm{x} 04 \mathrm{~b} 0$;

*PWM2_ENB $=0 \mathrm{x} 01$;

*PPI_CTLR = 0x90;

//Habilita o PWM Clock

$/ / \mathrm{CLK} / 10$

$/ / 6250 \mathrm{~d}$

//Duty Cycle 1250d

//Habilita PWM2

//Configura PA como input, PB e PC como output 


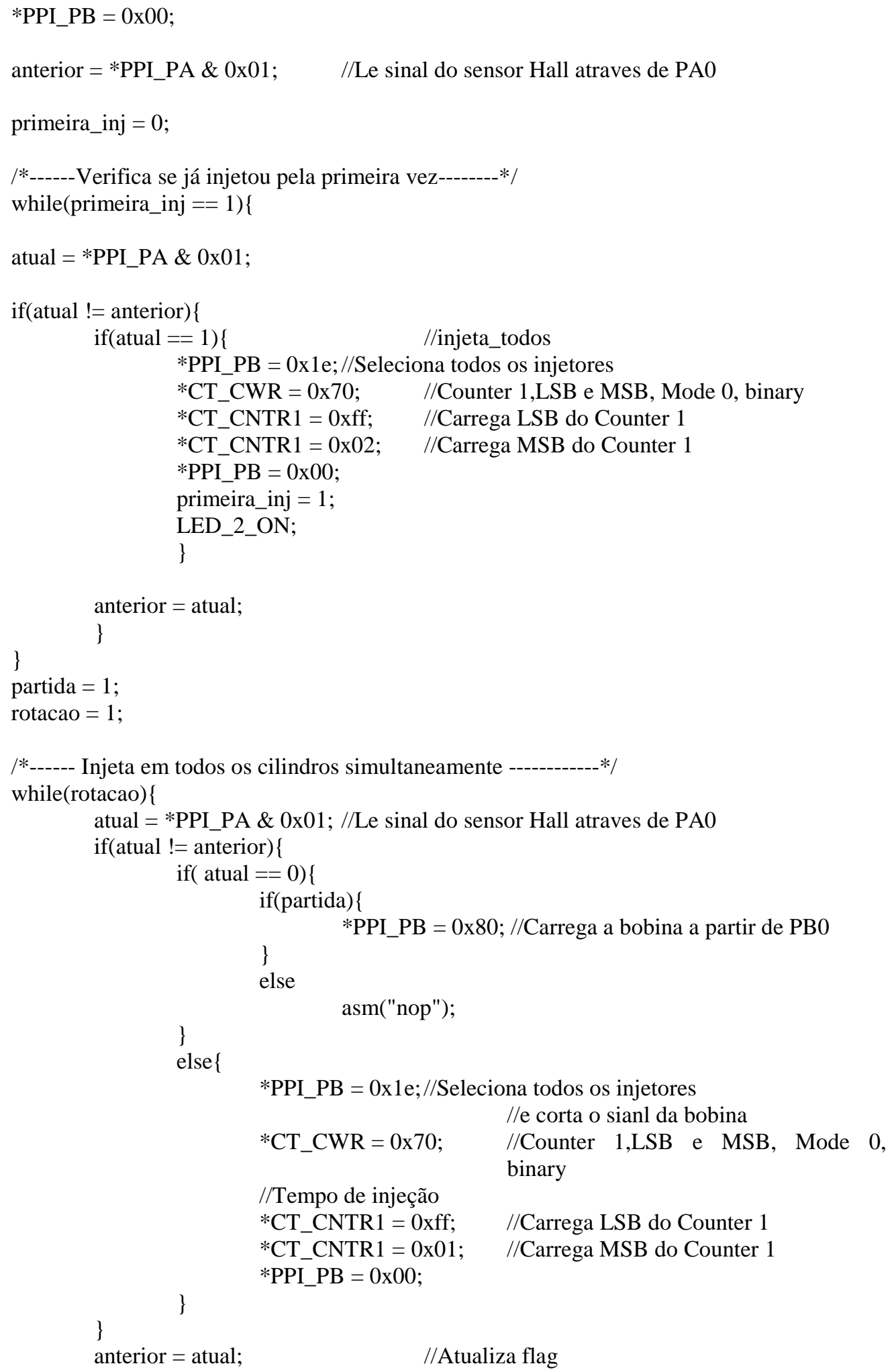




\section{LITERATURA REFERENCIADA}

(2001). Secretaria de Estado do Meio Ambiente. http://www.ambiente.sp.gov.br (04 Maio).

ABATE, M. et al. (1994). Application of Some New Tools to Robust Stability Analysis of Spark Ignition Engines: A case Study. IEEE Trans. Contr. Syst. Technol. v.2, n.1, p.2230, Mar.

AMEY, R. G. (1995). Automotive component innovation: development and diffusion of engine management technologies. Technovation, v.15, n.4, p.211-223.

ARM7TDMI Data Sheet (1995).

ARM Evaluation Board (1998). User Guide.

BALLUCHI, A. et al. (1999). Hybrid Control of the Air-fuel ratio in Force Transients for Multi-point Injection Engines. In: CONFERENCE ON DECISION \& CONTROL, 38., Phoenix, 1999. Proceedings. Arizona, USA. v.1, p.316-21.

BARTOLOMAIS Jr., L. (1989). Adeus Carburador. Quatro Rodas, ano 30, n. 1, p. 32-39.

BOSCH (1988). GmbH. Automotive electric/electronic systems. 1.ed. Warrendale, P.A.

BOSCH (1995). GmbH. Automotive electric/electronic systems. 2.ed. Warrendale, P.A.

BOSCH (1998). Gerenciamento de motor Motronic. Apostila técnica.

CHANG, C. et al. (1995). Air-Fuel Ratio Control in Spark-Ignition Engines Using Estimation Theory. IEEE Trans. Contr. Syst. Technol., v.30, n.1, p.22-31, Mar.

DOEBELIN, E. O. (1990). Measurement systems: application and design. 4.ed. McGrawHill.

DOLZA, J.; et al. (1957). The General Motors Fuel Injection System. SAE Transactions, v.65, p.739-57. /Apresentado ao SAE Annual Meeting, Detroit, USA, 1957/

GARCIA, O. (1988). Motores de combustão interna. São Paulo, DER-SP. 
GIVENS, L. (1976). Cadillac's electronic fuel injection. Automotive Engineering, v.84, n.2, p.18-23, Feb.

GLÖCKLER, O.; MANGER, H. (1981). Gasoline fuel injection: as overview. Automotive Engineering. v.89, n.1, p.66-74.

KAWAI, M. et al. (1999). High precision A/F control ECU for ultra low emission vehicles. JSAE Review, v.20, p.191-6.

KISHI, N. et al. (2000). The research of zero level emission vehicle using gasoline engine: efficient method for using the hybrid catalyst and EHC. JSAE Review. v.21, p.9-14.

LENZ, H. P. Mixture Formation in Spark-Ignition Engines. Warrendale, SAE, 1992.

NYSTROM, C. H. (1958). Automotive Gasoline Injection. SAE Transactions, v.66, p.65-74. /Apresentado ao meeting of the SAE Cleveland Section, Cleveland, USA, 1957/

PASSARINI, L. C. (1993). Projeto e análise de válvulas eletromagnéticas injetoras de combustível: uma nova proposta. São Carlos. 388p. Tese (Doutorado) - Escola de Engenharia de São Carlos, Universidade de São Paulo.

PASSARINI, 1. C. (2002). Análise e projeto de válvulas injetoras.1.ed. São Carlos, SP. EESC/USP, v.1. p.250.

RIBBENS, W. B.; MANSOUR, N. P. (1993). Understanding Automotive Electronics. 4.ed. Indianapolis, Sams Publishing.

ROSSI, C.; TILLI, A.; TONIELLI, A. (2000). Robust Control of a Throttle Body for Drive by Wire Operation of Automotive Engines. IEEE Trans. Contr. Syst. Technol. v.8, n.6, p.993-1002, Nov.

SHARP. LH77790A/B Embedded Microcontroller. User's Guide.

SHELEF, M.; MCCABE, R. W. (2000). Twenty-five years after introduction of automotive catalysts: what next? Catalysis Today, v.62, p.35-50.

STEFANOPOULOU, A. G.; FREUDENBERG, J. S.; GRIZZLE, J. W. (2000). Variable Camshaft Timing Engine Control. IEEE Trans. Contr. Syst. Technol. v.8, n.1, p.23-34, Jan.

STOTSKY, A.; EGARDT, B.; ERIKSSON, S. (1999). Variable structure control of engine idle speed with estimation of unmeasurable disturbances. In: CONFERENCE ON DECISION \& CONTROL, 38., Phoenix, 1999. Proceedings. Arizona, USA. v.1, p.32227.

TAKAGI, S. et al. (1998). Transient exhaust gas improvement by adaptive neural network. JSAE Review, v.19, p.15-19. 
THORNHILL, M.; THOMPSON, S.; SINDANO, H. (2000). A comparison of idle speed control schemes. Control Engineering Practice, v.8, n.5, p.519-30, May.

WINKLER, A. H.; SUTTON, R. W. (1957). Electrojector - Bendix electronic fuel injection system. SAE Transactions, v.65, p.758-68. /Apresentado ao SAE Annual Meeting, Detroit, USA, 1957/ 


\section{LITERATURA CONSULTADA}

BARCLAY, K, A. (1990). ANSI C: problem-solving and programming. Edinburgh, Prentice Hall.

BARRON, M. B.; POWERS, W. F. (1996). The Role of Electronic Controls for Future Automotive Mechatronic Systems. IEEE Trans. on Mechatroncs. v.1, n.1, p.80-88, Mar.

BIGNELL, J. W; DONOVAN, R. L. (1995). Eletrônica digital: lógica seqüencial. v.2 São Paulo, Makron Books.

BRANDT, E. P.; WANG, Y.; GRIZZLE, J. W. (2000). Dynamic Modeling of a Three-Way Catalyst for SI Engine Exhaust Emission Control. IEEE Trans. Contr. Syst. Technol. v.8, n.5, p.767-76, Sept.

GLASS, J. W.; FRANCHEK, M. A. (1999). NARMAX modelling and robust control of internal combustion engines. Int. J. Control. v.72, n.4, p.289-304.

JONES, V. K. et al. (1995). Identification and Air-Fuel Ratio Control of a Spark Ignition Engine. IEEE Trans. Contr. Syst. Technol. v.3, n.1, p.14-21, Mar.

LOPES, J. A. (1996). Um controlador preditivo generalizado (GPC) aplicado ao problema de controle da relação ar-combustível em motores ciclo Otto, operando com gás natural, com vistas em redução de emissões. São Paulo. 134p. Dissertação (Mestrado) - Escola Politécnica, Universidade de São Paulo.

MONNERAT JÚNIOR, P. H. (2000). Controle neural para marcha lenta de veículos. Campinas. 95p. Dissertação (Mestrado) - Faculdade de Engenharia Elétrica e de Computação, Universidade Estadual de Campinas.

NATIONAL INSTRUMENTS (1997a). DAQ - DAQScope ${ }^{T M} 5102$ User Manual.

NATIONAL INSTRUMENTS (1997b). VirtualBench - Getting Started with VirtualBench.

NWAGBOSO, C. O. (1993). Automotive Sensory Systems. 1. Ed. CHAPMAN \& HALL, London. 
OBERT, E. F. (1968). Internal Combustion Engines. 3.ed. Scranton, Pennsylvania, International Textbook Company.

POWELL, J. D.; FEKETE, N. P. CHANG, C. (1998). Observer-Based Air-Fuel Ratio Control. IEEE Control Systems. v.18, n.5, p.72-83, Oct.

POWERS, W. F.; NICASTRI, P. R. (2000). Automotive vehicle control challenges in the $21^{\text {st }}$ century. Control Enginnering Practice. v.8, p.605-18.

QUEIROZ, R. (1993) Injetando Progresso. Tecnologia Automotiva. v.8, n.2, p.9-12.

ZILLNER, M. (2000). O software de funcionamento dos Módulos de Injeção Eletrônica parte 1. Oficina Brasil. n.116, p.16-17, out.

ZILLNER, M. (2000). O software de funcionamento dos Módulos de Injeção Eletrônica parte 2. Oficina Brasil, n.117, p.16-17, nov. 


\section{APÊNDICE I}

\section{Fatores médios de emissões veiculares.}

Os gráficos a seguir, ilustram a redução na emissão de $\mathrm{CO}, \mathrm{HC}, \mathrm{NO} \mathrm{X}_{\mathrm{X}} \mathrm{CHO}$ e a redução de emissões evaporativas, para veículos movidos a gasool (gasolina + etanol) e etanol, mostrando também, os respectivos limites impostos pela legislação brasileira, de acordo com dados da SECRETARIA DE ESTADO DO MEIO AMBIENTE.

\section{Evolução da Emissão de CO}

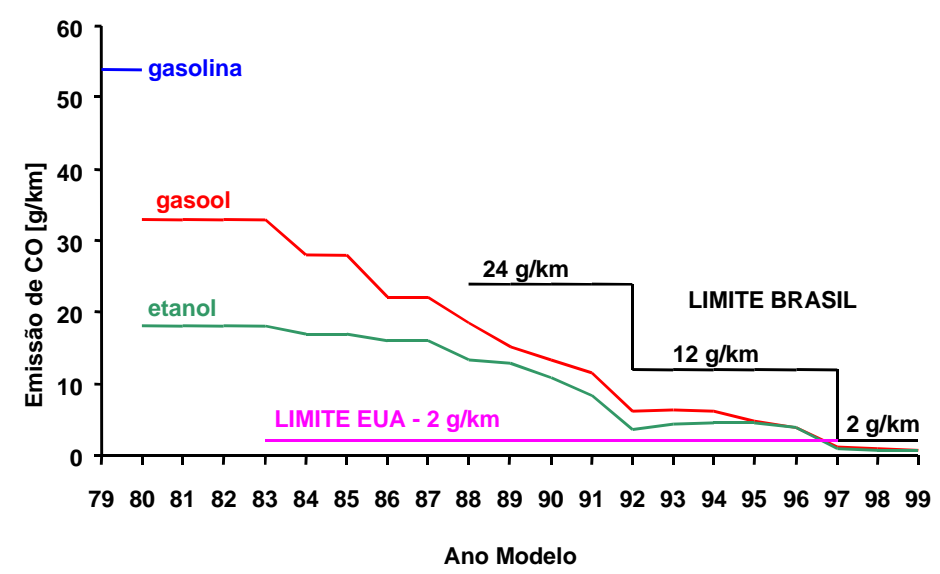

FIGURA 46 - Emissão média de CO para veículos movidos a gasool e etanol e o respectivo limite. [http://www.ambiente.sp.gov.br] 
Evolução da Emissão de HC

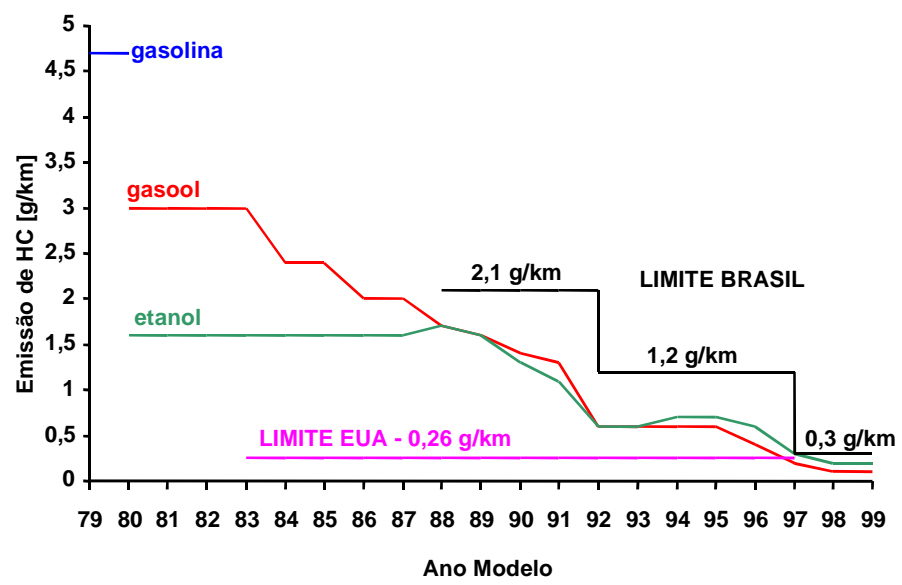

FIGURA 47 - Emissão média de $H C$ para veículos movidos a gasool e etanol e o respectivo limite. [http://www.ambiente.sp.gov.br]

\section{Evolução da Emissão de NOx}

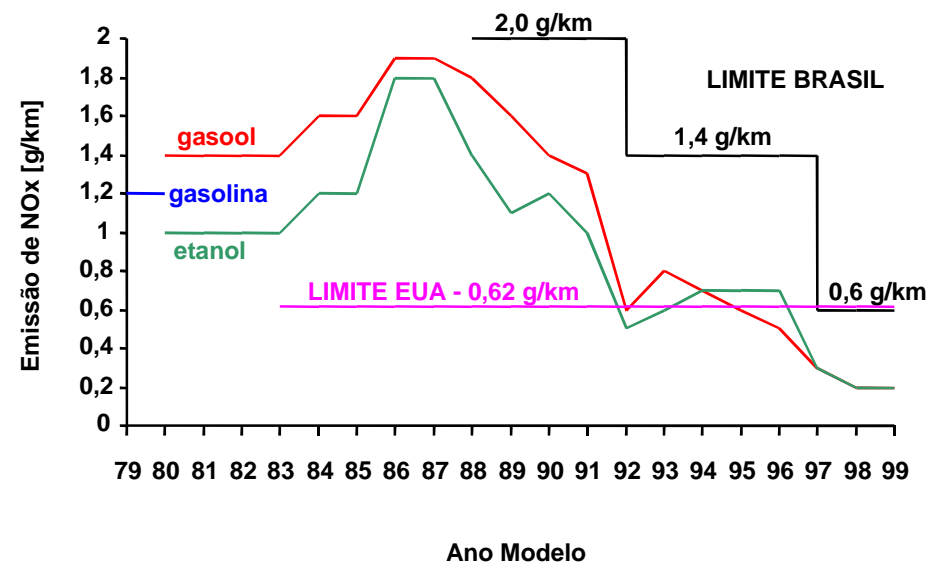

FIGURA 48 - Emissão média de $N O_{x}$ para veículos movidos a gasool e etanol e o respectivo limite. [http://www.ambiente.sp.gov.br] 
Evolução da Emissão de CHO

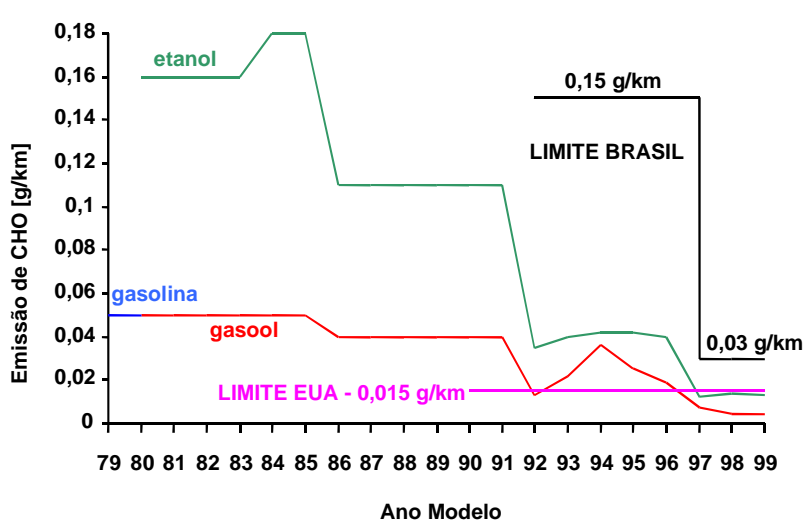

FIGURA 49 - Emissão média de $C H O$ para veículos movidos a gasool e etanol e o respectivo limite. [http://www.ambiente.sp.gov.br]

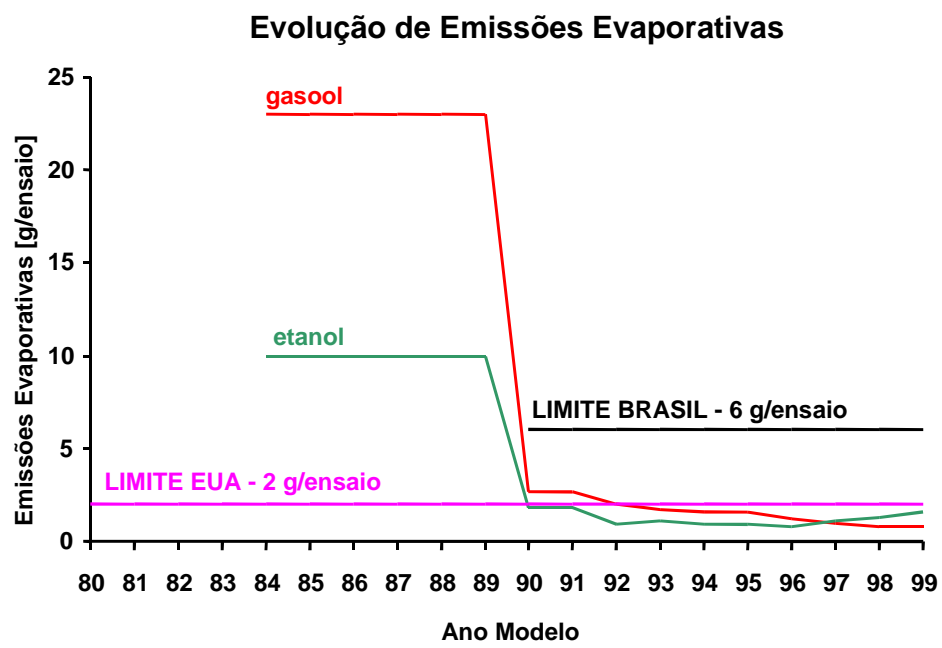

FIGURA 50 - Média de emissões evaporativas para veículos movidos a gasool e etanol e o respectivo limite. [http://www.ambiente.sp.gov.br] 